\title{
Islamic State of Afghanistan: Rebuilding a Macroeconomic Framework for Reconstruction and Growth
}

This paper on rebuilding a macroeconomic framework for reconstruction and growth for the Islamic Republic of Afghanistan was prepared by a staff team of the International Monetary Fund as background documentation for the periodic consultation with the member country. It is based on the information available at the time it was completed on September 5, 2003. The views expressed in this document are those of the staff team and do not necessarily reflect the views of the government of the Islamic Republic of Afghanistan or the Executive Board of the IMF.

The policy of publication of staff reports and other documents allows for the deletion of market-sensitive information.

To assist the IMF in evaluating the publication policy, reader comments are invited and may be sent by e-mail to publicationpolicy@imf.org.

Copies of this report are available to the public from

International Monetary Fund • Publication Services

$70019^{\text {th }}$ Street, N.W. • Washington, D.C. 20431

Telephone: (202) 623-7430 • Telefax: (202) 623-7201

E-mail: publications@imf.org•Internet: http://www.imf.org

Price: $\$ 15.00$ a copy

\section{International Monetary Fund \\ Washington, D.C.}




\title{
INTERNATIONAL MONETARY FUND
}

\section{ISLAMIC STATE OF AFGHANISTAN \\ Rebuilding a Macroeconomic Framework for Reconstruction and Growth}

\author{
Prepared by a staff team comprising \\ Messrs. A. Bennett (ed.), B. de Schaetzen, R. van Rooden (all MED), \\ L. Dicks-Mireaux (PDR), F. Fischer (MFD), and T. Kalfon (FAD) \\ Approved by the Middle Eastern Department
}

September 5, 2003

Contents

Map. 4

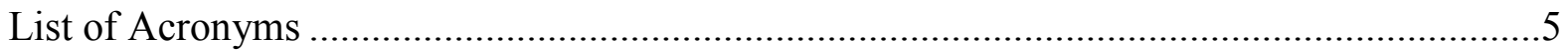

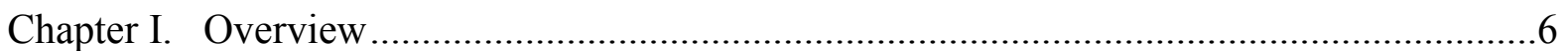

I. The Political Landscape ....................................................................... 6

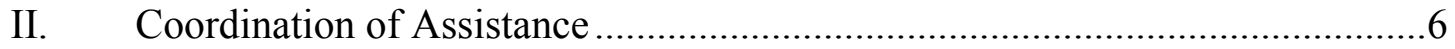

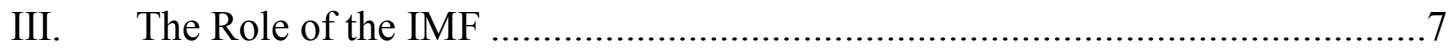

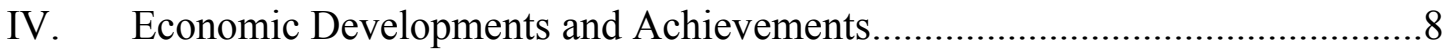

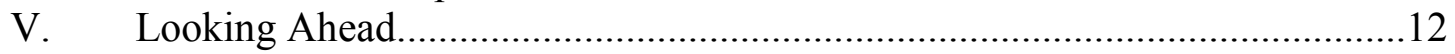

Chapter II. Recent Macroeconomic Developments .......................................................... 14

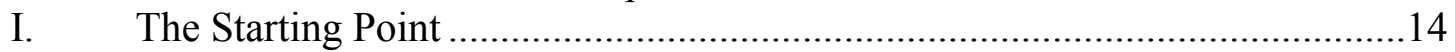

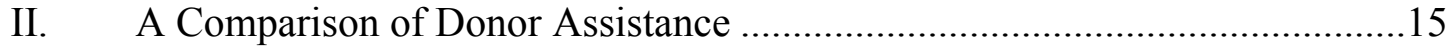

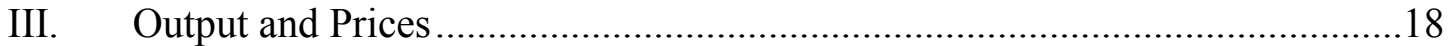

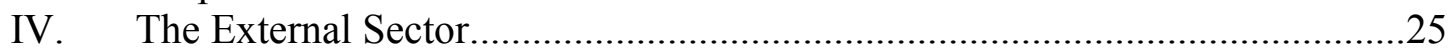

Annex II.1. The Poppy Dimension in the Afghan Economy ...................................36

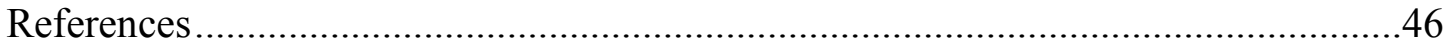

Chapter III. The Fiscal Framework and the Budget .......................................................47

I. Overview of Past Fiscal Developments: A Slow Descent Into Chaos.............47

II. The Starting Point: A Dismal Situation But Resilient Structures ....................49

III. The Reconstruction Strategy: From Donor-Led Humanitarian Assistance to Government-Driven Reconstruction ..........................................51

IV. The Fiscal Policy Framework: Post-Conflict Budgeting ...............................56

Annex III.1 The Twelve National Programs of Afghanistan's National Development Framework ................................................. 71 
Annex III.2. Comparison Between Afghanistan's 2002/03 Operating Budget and the Budgets of a Sample of Low-Income Countries .....................74

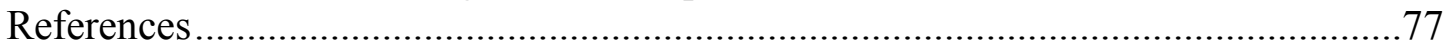

Chapter IV. Structural Reforms: Revitalizing the Fiscal Institutions .................................78

I. Improving Public Expenditure Management: Providing Assurances of

Transparency and Accountability ............................................. 78

II. Reforming Revenue Policy and Administration: Enhancing Domestic

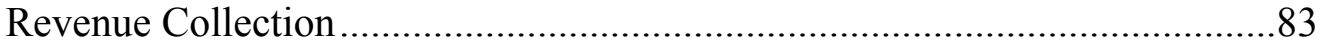

III. Revitalizing the Civil Service .............................................................. 87

IV. Developing the Private Sector: Building a Market-Led Economy ...................90

Annex IV.1. Pay Structure for Government Staff................................................93

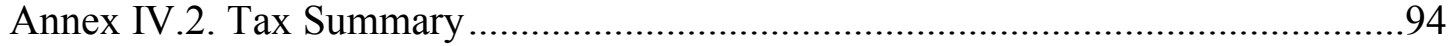

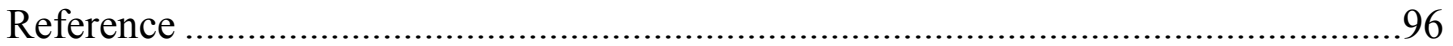

Chapter V. Monetary and Exchange Rate Policy in a Post-Conflict Environment:

Simple Rules and Flexibility.....................................................................97

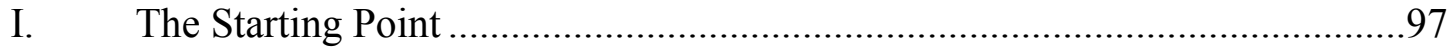

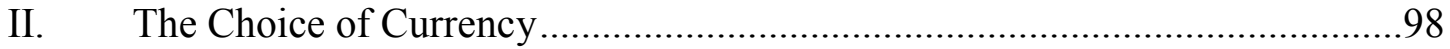

III. Preconditions for a Successful Monetary Policy ............................................99

IV. Fixed or Flexible: the Choice of the Exchange Rate Regime ........................103

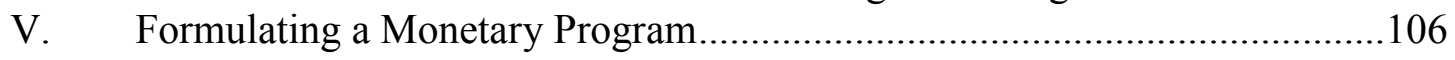

VI. Monetary and Exchange Rate Developments in 2002-03 ..........................110

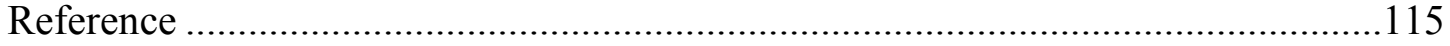

Chapter VI. Financial Sector Development in Afghanistan:

Seeking a Renaissance ........................................................................116

I. After the Taliban: The Financial System at the End of 2001 .......................116

II. Modernizing the Financial Sector in Afghanistan .......................................129

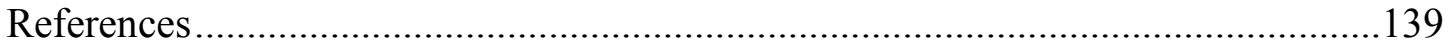

\section{Text Boxes}

I.1 The Asian Development Bank in Afghanistan ............................................... 8

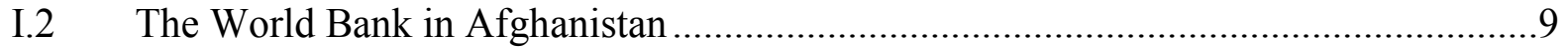

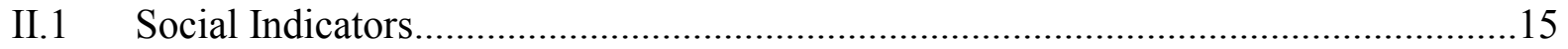

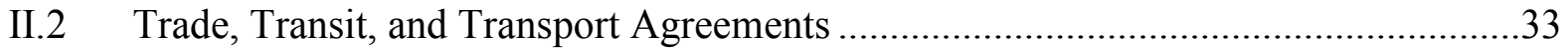

II.3 Exchange and Trade Arrangements in Afghanistan ...............................................34

III.1 The Public Sector in Afghanistan and the Relationship

Between the Center and the Provinces.............................................................50

III.2 The 2001-02 United Nation's Immediate and Transitional Assistance Programs ......53

III.3 The Afghanistan Reconstruction Trust Fund ....................................................62

IV.1 Exchange Rates Currently Used in Customs Valuation ............................................84

V.1 Introducing the New Currency...................................................................... 100

V.2 What is the Right Exchange Rate Level? .........................................................105 


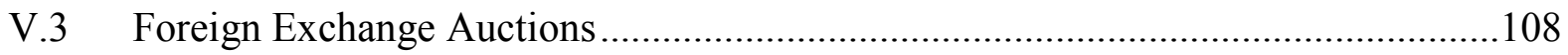

V.4 Considerations on the Level of Foreign Exchange Reserves....................................111

VI.1 The Law on Money and Banking of the Islamic State of Afghanistan.......................118

VI.2 The Physical Infrastructure and Security of Da Afghanistan Bank ............................120

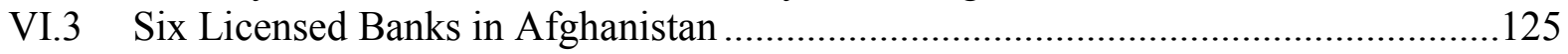

VI.4 The Money Dealers in Afghanistan ....................................................................130

Text Tables

II.1 Gross Domestic Product, 2001/02-2002/03 ……...............................................19

II.2 Selected Indicators of Economic Activity, 1999-2003 ………................................20

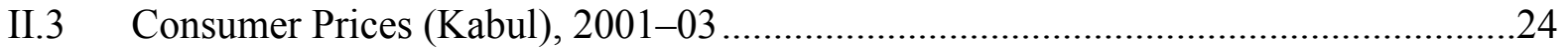

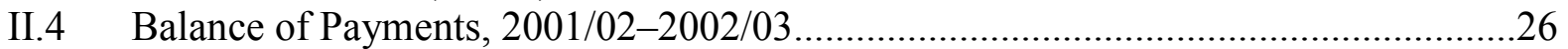

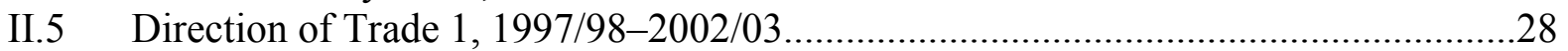

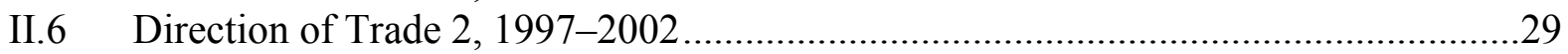

II.7 Commodity Composition of Trade, 1997/98-2002/03 ...............................................

III.1 General Government Current Budget, 2002/03 ……..............................................5

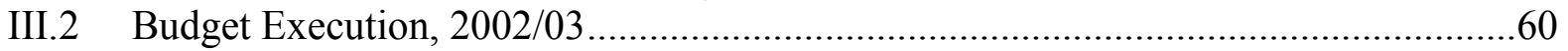

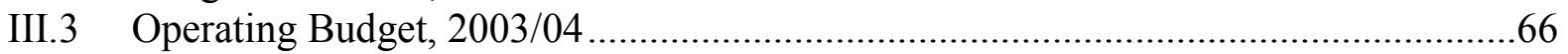

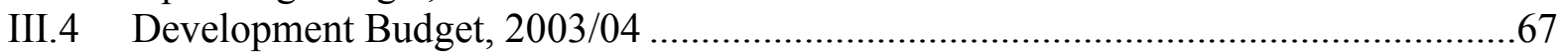

III.5 Operating Budget, 2003/04 (Execution for the first five months of the year)............69

V.1 Monetary Developments (Da Afghanistan Bank), 2001-04 ....................................109

V.2 Afghani/U.S. dollar Exchange Rates (Cash), 1999-2003 .......................................114

Figures

II.1 Post-Conflict Countries: Comparison of Foreign Assistance ......................................17

II.2 Price and Exchange Rate Developments, 2001-03 ...................................................23

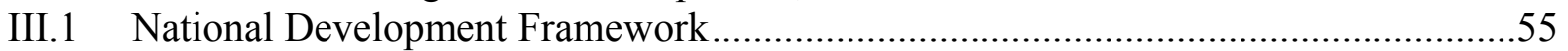

III.2 Budget Execution —Economic Classification, 2002/03 ............................................61

III.3 Budget Execution — Functional Classification, 2002/03 ............................................61

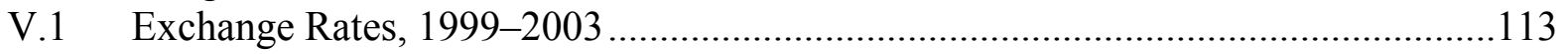

Annexes Tables

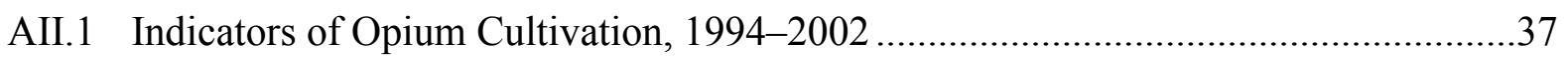

AII.2 Estimate of Farmers' Net Income for Opium, 1994-2002 ……................................40

AII.3 Revenues from Opiates, 2002-02 …………….....................................................

AIII.1 Budget of Afghanistan Compared to the Budget of

Selected Low-Income Countries, 2002/03 ........................................................75

AIII.2 Low-Income Countries Used for Comparison with the 


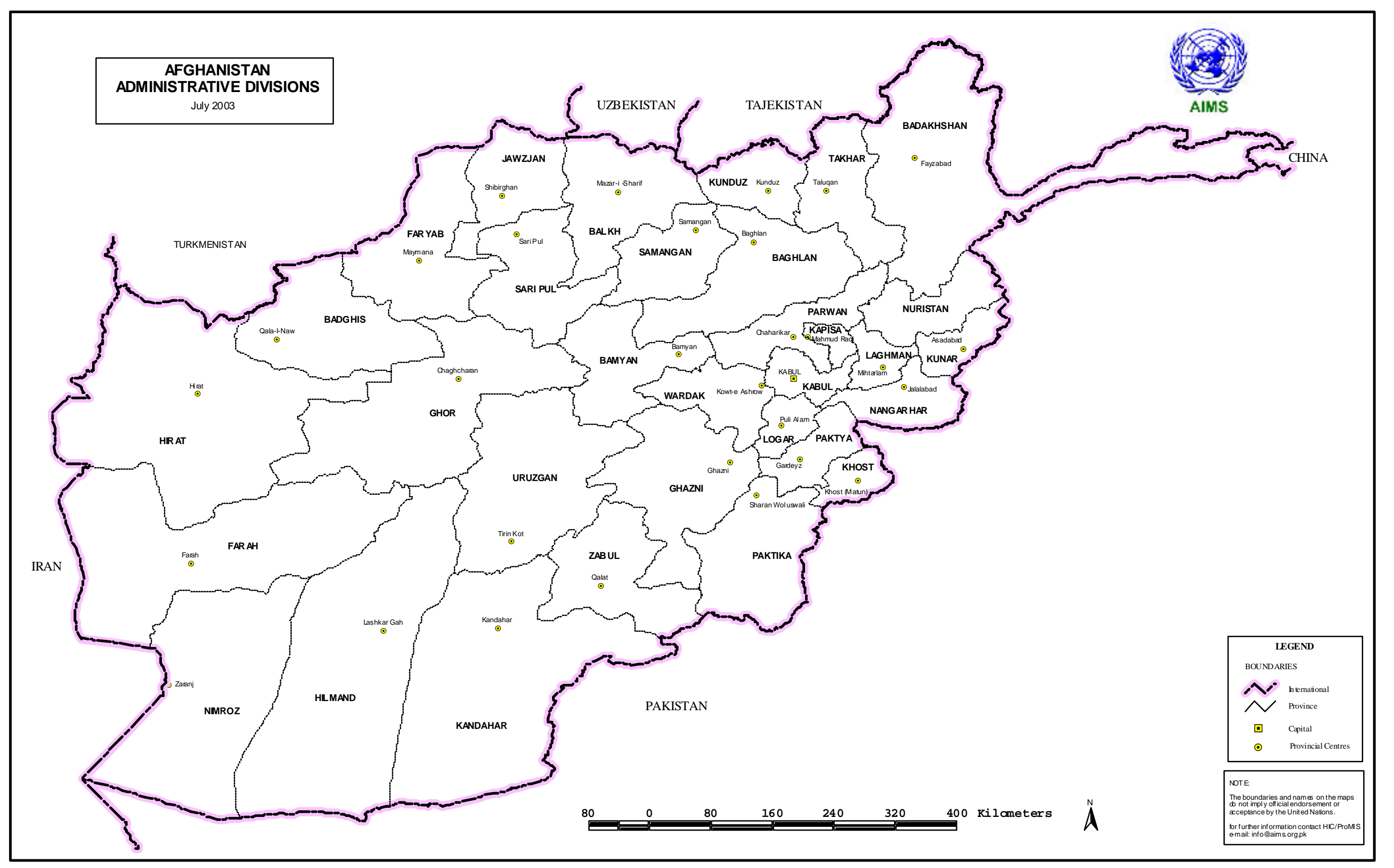




\section{List of Acronyms}

\begin{tabular}{|c|c|}
\hline AACA & Afghan Aid Coordination Agency \\
\hline AFMIS & Afghanistan's Financial Management Information System \\
\hline AHSF & Afghanistan High-Level Strategic Forum \\
\hline AIA & Afghan Interim Administration \\
\hline AIAF & Afghan Interim Administration Fund \\
\hline ARCSC & Administrative Reform and Civil Service Commission \\
\hline ARTF & Afghanistan Reconstruction Trust Fund \\
\hline AsDB & Asian Development Bank \\
\hline ATA & Afghan Transitional Administration \\
\hline $\mathrm{CG}$ & Consultative Group \\
\hline CIRR & Commercial Interest Reference Rates \\
\hline CIT & Corporate income tax \\
\hline $\mathrm{CSO}$ & Central Statistics Office \\
\hline DAB & Da Afghanistan Bank \\
\hline $\mathrm{ECO}$ & Economic Cooperation Organization \\
\hline FAO & Food and Agriculture Organization \\
\hline GMU & Grant Management Unit \\
\hline IAS & International Accounting Standards \\
\hline ICMP & Illicit Crop Monitoring Program \\
\hline IDA & International Development Association \\
\hline IG & Implementation Group \\
\hline ISAF & International Security Assistance Force \\
\hline IsDB & Islamic Development Bank \\
\hline ITAP & Immediate and Transitional Assistance Programs \\
\hline LOTFA & Law and Order Trust Fund for Afghanistan \\
\hline LTU & Large Taxpayer Unit \\
\hline MoF & Ministry of Finance \\
\hline NCR & National Cash Registry \\
\hline NDB & National Development Budget \\
\hline NDF & National Development Framework \\
\hline PRGF & Poverty Reduction and Growth Facility \\
\hline PIT & Personal income tax \\
\hline RTGS & Real Time Gross Settlement \\
\hline SG & Steering Group \\
\hline SOEs & State-owned enterprises \\
\hline TAPA & Transitional Assistance Programs for Afghanistan \\
\hline TIN & Taxpayer identification number \\
\hline UNDCP & United Nations International Drug Control Program \\
\hline UNDP & United Nations Development Program \\
\hline UNODC & United Nations Office on Drugs and Crime \\
\hline WFP & World Food Progra \\
\hline
\end{tabular}




\section{Chapter I. OVERVieW ${ }^{1}$}

\section{The Political Landscape}

1. After more than two decades of conflict, a new opportunity for the peaceful development of Afghanistan emerged with the fall of the Taliban regime in late 2001 and the political agreement reached between the various Afghan factions in Bonn in December 2001. The years of fighting had started with the former Soviet Union's intervention in Afghanistan in December 1979 to support the communist regime that had taken power in a military coup the previous year. The following 10 years saw fierce fighting, until the Soviet forces withdrew in 1989. In 1992, the Mujahedin took over Kabul and installed a new government. However, much of the country remained under the control of local warlords. In response to growing lawlessness and increased factional fighting, the Taliban movement emerged. The Taliban took Kabul in 1996 after heavy fighting between the various factions that left much of the city destroyed, and they eventually controlled almost 90 percent of the country. They made little effort, however, to form a civilian government and to provide public services. The military intervention following the tragic events of September 11, 2001 resulted in the collapse of the Taliban regime in late 2001 and the formation of a new government.

2. The 2001 Bonn agreement provided a road map for the creation of a peaceful, democratic state. An Afghan Interim Administration (AIA) was appointed and governed for six months until an Emergency Loya Jirga (grand council) of some 1,500 delegates could be convened in June 2002. The Loya Jirga chose a new Afghan Transitional Administration (ATA), headed by President Karzai, that will remain in office for two years. The ATA is charged with preparing a new constitution and free and fair elections to elect a fully representative government. Work is underway in both areas. A Constitutional Drafting Commission was created in late 2002 to prepare a draft of the new constitution, and a Constitutional Commission was established in April 2003 to seek the opinions of the Afghan population regarding their future constitution. On the basis of this broad consultation, the Constitutional Commission will review the work of the drafting commission and prepare a draft constitution that will be submitted to a Constitutional Loya Jirga in late 2003. Elections are to be held in 2004 (within two years after the Emergency Loya Jirga). This will be a challenging task, made even more difficult by the logistical and security concerns, as well as a lack of basic information such as a register of voters. The United Nations (UN) is working closely with the Afghan authorities to prepare for this major undertaking.

\section{CoOrdination of Assistance}

3. The task of rebuilding Afghanistan is an enormous one, requiring strong support from the international community. Already before the AIA came to office, the international community organized a number of meetings on Afghanistan's reconstruction, starting in the fall of 2001. This included the creation of a Steering Group (SG) of donor governments to

\footnotetext{
${ }^{1}$ Prepared by Ron van Rooden.
} 
enhance international political support for the reconstruction process and provide strategic guidance. Co-chairs of the SG were the United States, Japan, Saudi Arabia, and the European Union. In November 2001, the SG requested the World Bank, the Asian Development Bank (AsDB), and the United Nations Development Program (UNDP) to produce a preliminary needs assessment for Afghanistan's reconstruction. This assessment was presented at the International Conference on Reconstruction Assistance to Afghanistan in Tokyo in January 2002. The conference generated pledges of assistance for Afghanistan's reconstruction totaling $\$ 4.5$ billion, with $\$ 1.8$ billion in pledges for the first year.

4. During the past two years, the leadership and ownership of the coordination of the reconstruction process was steadily transferred to the Afghan authorities. In early 2002, an Implementation Group (IG) was established, chaired by the government and with the AsDB, the UNDP, the Islamic Development Bank (IsDB), and the World Bank as vice-chairs to facilitate the coordination of assistance. IG meetings were held in Kabul in March and September of 2002. The SG/IG structure evolved in early 2003 into a normal Consultative Group (CG) mechanism and the first major CG meetings-Afghanistan Development Forum and Afghanistan High-Level Strategic Forum - were held in March 2003, in Kabul and Brussels, respectively.

5. The authorities strengthened their responsibility to coordinate and manage the reconstruction effort by adopting a National Development Framework (NDF) in 2002. The NDF focuses on three pillars of development: (a) security and human development; (b) rebuilding physical infrastructure; and (c) enabling the creation of a viable private sector as the engine for sustainable and inclusive economic growth. For each of these pillars, broad sectoral programs have been developed and individual CGs established that provide the framework for identifying and selecting individual projects within the overall resource envelope. This process culminated in the National Development Budget (NDB), which translated the broad priorities and programs of the NDF into detailed and prioritized development projects that are to be funded through the budget.

\section{THE ROLE OF THE IMF}

6. Since January 2002, at the request of the Afghan authorities, the International Monetary Fund has been providing extensive policy advice and technical assistance in its areas of expertise. ${ }^{2}$ The focus of this assistance was, and continues to be, to ensure that sound foundations for economic management and macroeconomic stability be established as quickly as possible; this would provide the necessary basis for reconstruction and sustained economic recovery. This assistance included helping the authorities to rehabilitate key economic institutions, in particular the Ministry of Finance (MoF) and the central bank, Da Afghanistan Bank (DAB). The IMF Fiscal Affairs Department has focused on improving expenditure management and the tax system. The IMF Monetary and Financial Systems Department assisted with the introduction of the new currency, central bank modernization,

\footnotetext{
${ }^{2}$ In August, 2002, the IMF opened a resident representative office in Kabul, and in February, 2003, Afghanistan cleared its arrears to the IMF.
} 
and, together with the IMF Legal Department, the preparation of new financial sector legislation. The IMF Statistics Department provided assistance on a new framework for macroeconomic statistics. This technical assistance is ongoing and will continue to be available in the future. In addition, a staff team from the IMF Middle Eastern, Fiscal Affairs, and Policy Development and Review Departments has been assisting, and is continuing to assist, the authorities in developing a macroeconomic framework to guide economic decision-making aimed at achieving a sustainable, noninflationary recovery. Policy advice has centered on issues crucial to a quick restoration of macroeconomic stability, including the formulation and execution of fiscal policy, as well as the choice of currency arrangement, and the design and conduct of monetary policy.

\section{ECONOMIC DEVELOPMENTS AND ACHIEVEMENTS}

7. From the outset, the Afghan authorities have been strongly committed to achieving financial stability and maintaining fiscal discipline to support the reconstruction and recovery of the economy. They also sought to establish transparency in government operations and improve economic management. The economy would be based on liberal and open markets, led by private sector activity with low state intervention. Also, the external trade, payments, and exchange systems would be open and liberal; and private sector investment would be promoted. In their efforts to achieve all these goals, the authorities received the support of the IMF, the AsDB (Box I.1), the World Bank (Box I.2), various UN agencies, and numerous bilateral donors. This report provides an overview of institutional and economic achievements in Afghanistan from late 2001 up to September 2003.

\section{Box I.1. The Asian Development Bank in Afghanistan}

1. Afghanistan was a founding member of the Asian Development Bank (AsDB) in 1966. By the time of the Soviet occupation in 1979 and the suspension of AsDB operations, Afghanistan had received nine loans totaling \$95.1 million from the Asian Development Fund (ADF), and grant technical assistance (TA) totaling \$2.5 million.

2. Since the Afghanistan Interim Administration was installed in December 2001 and AsDB operations were resumed, AsDB has been substantially engaged in assisting Afghanistan. During 2002, AsDB provided \$15 million in capacity building technical assistance grants, and administered a further $\$ 22$ million in grant-funded pilot projects from the Japan Fund for Poverty Reduction (JFPR). In 2003, AsDB expects to provide an additional $\$ 10$ million in capacity building TA grants, and \$43 million in grants from JFPR and the Kuwait Fund for Arab Economic Development. The AsDB has already committed a total of $\$ 300$ million in a Postconflict Multisector Program Loan (\$150 million) approved on December 4, 2002 and an Emergency Infrastructure Rehabilitation and Reconstruction Project (EIRRP) Loan (\$150 million), approved on June 3, 2003. Of the former, $\$ 100$ million has been disbursed, and the remaining $\$ 50$ million will be disbursed by end2003 subject to the completion of a number of policy and institutional reforms to improve governance and strengthen the financial, transport, and energy sectors. The EIRRP is assisting the government in restoring key infrastructure in Afghanistan's transport (roads) and energy (electric power and gas) sectors. In addition, an agricultural sector program loan (\$50 million) is under discussion.

4. The AsDB approved a Country Strategy and Program Update (CSPU) for Afghanistan in June 2003 for the period 2003-05, for which $\$ 610$ million has been earmarked. The CSPU covers three broad sectors: (a) transportation (roads and civil aviation); (b) energy (power, gas, and petroleum); and (c) natural resources (agriculture, irrigation, and environment). Some \$10 million per year in technical assistance is planned in various areas during 2003-05.

5. All these loans are concessional, with a grant element equivalent to around 60 percent. The first repayment from the loans extended since the current administration assumed office is not scheduled until 2013. There are, however, a number of old outstanding loans that Afghanistan has resumed servicing, and this generates a small debt service obligation for the Afghan authorities of about $\$ 1.3$ million per year during 2003-11 (with further declining amounts thereafter). 


\section{Box I.2. The World Bank in Afghanistan}

1. Following the end of the Taliban era, the World Bank quickly resumed its longstanding relationship with Afghanistan, and in May 2002, it officially reopened its office in Kabul. Since April 2002, the World Bank has committed \$186.8 million in grants and an additional \$128.4 million in no-interest loans ("credits"), for development projects including improving roads; increasing the power supply in Kabul; cleaning up municipal waste; repairing schools; and improving health services. These funds are also being used towards strengthening public administration, developing the national highway and civil aviation.

2. In addition to the above, the World Bank is administering a number of activities financed through separate trust fund facilities. These include projects funded under a \$50 Japan Social Development Fund (JSDF) — including community rehabilitation and local infrastructure development and capacity building within the Ministry of Health. In addition, a number of projects have been funded from the World Bank Post-Conflict Fund, including teacher training programs implemented by NGOs, technical assistance in key areas requested by government, early impact projects and technical assistance in a range of priority sectors and a database of expatriate Afghan expertise. The World Bank is also acting as the administrator of the multilaterally supported Afghanistan Reconstruction Trust Fund (ARTF) which is being used to cover government recurring costs and salaries, as well as financing a number of new projects in areas such as microfinance, telecommunications, and infrastructure.

3. In March 2003, the World Bank finalized its Transitional Support Strategy (TSS) for Afghanistan, designed to support the government's National Development Framework. The TSS outlines the World Bank's assistance to Afghanistan over a period of 18 months to 2 years. The strategy focuses on four key areas: improving livelihoods; assisting with the government's fiscal strategy, institutional development, and management; supporting governance and public administration reform; and helping to enable private sector development in Afghanistan. The TSS envisages operations amounting to $\$ 470$ million over FY2003 and FY2004. The World Bank has some pre-Taliban loans on which debt service of approximately $\$ 3.0$ millions falls due in FY2003.

8. Chapter II confirms the strong economic recovery that has recently taken place. Economic growth, excluding opium production, is estimated to have reached almost 30 percent in 2002/03 and is expected to continue at a rate of about 20 percent in 2003/04. ${ }^{3}$ This recovery is most visible in agriculture, reflecting the end of a prolonged drought, and in the construction and services sectors, where the rapid expansion is largely driven by donor assistance. Per capita GDP is estimated to have reached some \$180-190 in 2002/03, although this is still one of the lowest levels in the world.

9. While the formal economy is recovering, so is the production of opium. This is having a profound impact on the economy, with the share of the opium sector in the economy estimated to be about half. The ban on poppy cultivation imposed by the Taliban in 2000 was very successful, but opium production is now back up to the levels of the late 1990s. Apart from improved weather conditions and an increase in area under cultivation, the reemergence of poppy cultivation is an indication of the lack of alternative livelihoods and the limited control of the central government beyond Kabul.

10. Although donor assistance has been sizable, a comparison of aid levels with other recent post-conflict countries suggests that aid flows to Afghanistan so far have been relatively low. Disbursements have been high compared to pledged amounts, but pledges

\footnotetext{
${ }^{3}$ Afghan solar year 1381 ran from March 21, 2002 until March 20, 2003, while the solar year 1382 runs from March 21, 2003 until March 19, 2004.
} 
may have been low compared to actual needs. Putting the country back on its own feet will continue to require sizable international assistance over the next several years. This assistance will need to be overwhelmingly in the form of grants to avoid possible future debt servicing difficulties.

11. In Chapter III, the formulation and implementation of the government's budgetary policy is traced, within the broader context of the government's overall reconstruction strategy. Afghanistan's fiscal policy, as embodied by the 2002/03 and 2003/04 operating and development budgets, has been characterized by a strong commitment to respect fiscal discipline and refrain from monetary financing (the "no-overdraft rule"); the 2002/03 budget financing gap was entirely covered by donor support and the 2003/04 budget is based on the same principle. In 2002/03, expenditures are estimated to have reached \$349 millionmostly spent on government salaries (including those of the provinces) and on the security and social sectors - while domestic revenues turned out much higher than expected, at $\$ 132$ million. The execution of the 2002/03 budget was, however, seriously hampered by the lack of unity of the fiscal system. Only a very small amount of the locally collected revenues were transferred to the center, and little information was available on provincial nonwage expenditures.

12. The 2003/04 operating budget adopted in March 2003 constituted a huge improvement in procedures compared with the previous year. It envisages a considerable increase in government expenditures, to $\$ 550$ million, with the increase concentrated in the security and education sectors. It also targets a sharp rise in domestic revenues, to \$200 million. Preliminary execution data suggest that expenditures have been off to a slow start, mainly because of delays in payroll disbursements. Domestic resources may reach the targeted \$200 million, if the current trends are sustained and with customs reform. The 2003/04 \$1.8 billion development budget provides a program of both reconstruction and humanitarian projects, whose outcome will depend on the availability of donor support and the authorities' implementation capacities.

13. For both the operating and development budgets to be executed fully this fiscal year, and thus for the government to be able to achieve its development objectives, it will be crucial that (a) domestic revenues increase as envisaged by implementing customs and subsequently tax reforms; (b) domestic revenues are effectively centralized through improved fiscal relations with the provinces; and (c) additional pledges of donor assistance are obtained and pledged assistance materializes in a timely manner. As of early September 2003, existing pledges were still short of the requirements of both the operating and development budgets.

14. Chapter IV offers more detail of the progress made in rebuilding fiscal institutions. The biggest strides were made in improving expenditure management, which was also the area where it was most needed in order for the government to be able to execute the budget and to provide (a still very basic level of) public services to the population. The authorities also made progress toward fiscal transparency and accountability. Difficulties remain in fiscal management of the provinces, but efforts are underway to increase the central government's grip on provincial finances. These efforts have started to bear fruit and 
significant amounts of revenues collected by the provinces have been transferred to the center so far in 2003/04.

15. With improved financial management, the immediate focus of reform has now shifted towards increasing revenue mobilization. The authorities' aim is that the operating budget be fully financed from domestic revenues within a few years time. To achieve this, the authorities have started with a comprehensive reform of customs policy and administration, to be followed by a reform of tax policy and administration. Only limited progress has been made so far in the difficult area of civil service reform, while the restructuring of the stateowned enterprise sector has yet to begin.

16. Chapter $\mathrm{V}$ provides an overview of the challenges and issues the authorities faced in the area of monetary and exchange rate policy. To regain control over the issuance of money, the authorities decided early on to introduce a new national currency, which would also be an important symbol of national unity and sovereignty. Replacing all banknotes in a postconflict country such as Afghanistan within a fairly short period posed tremendous logistical challenges. Nevertheless, after some initial difficulties that led to a spike in inflation in the fall of 2002, they succeeded in this difficult endeavor sooner than many had thought possible. The introduction of the new currency was a crucial step in the authorities' efforts to establish financial stability.

17. At the same time, the central bank needed a framework to conduct an independent monetary policy. The authorities decided that the primary objective of monetary policy should be to achieve and maintain price stability and thus to restore confidence in the (new) national currency. To do so, the central bank aims to control the domestic money supply, within the context of a floating exchange rate regime. On balance Afghanistan's existing economic conditions favor a floating exchange rate regime, at least for the near term. The authorities nonetheless see benefits in at least some degree of exchange rate stability to instill confidence in the new currency and to support price stability. Therefore, since the introduction and float of the new currency in early 2003, DAB has aimed to limit exchange rate volatility and to keep the exchange rate within a range, but without intending to resist persistent exchange rate pressures should these emerge. Monetary policy has been restrained so far, supported by the no-overdraft rule for the budget. As a result, prices have been broadly stable in 2003. Moreover, in the absence of any major shocks, exchange rate stability was established with the exchange rate fluctuating around Af 48 per U.S. dollar. As such, $\mathrm{DAB}$ - and the authorities in general - have made remarkable progress in achieving financial stability.

18. The renaissance of the financial sector will be vital to Afghanistan's economic development. Chapter VI provides a description of the parlous state of the financial sector by the end of the Taliban period and describes the progress that has been achieved so far, and what is needed to establish a modern-day financial system. The central bank had inherited the legacy of soviet-style banking and its sole function had become to print money to cover budget deficits. The existing six commercial and development banks had virtually ceased to 
function and they had lost the public's confidence. With a dysfunctional banking system, money traders (Hawala) had become the only providers of most banking services.

19. Since late 2001, the central bank has made important progress in restoring some key functions, especially in the areas of monetary policy, payments and supervision. While much remains to be done, road maps have or are being developed to bring DAB's organization, capacities, and functions fully in line with modern-day best practices. Most importantly, to underpin DAB's transformation and to enable the entry of new commercial banks, a new central bank law (providing DAB with autonomy) and banking law are to be enacted soon. The Hawala system may nonetheless continue to have a role in the financial system, notwithstanding newly emerging banks. Regarding the existing banks, diagnostic studies have been carried out and strategies for reform and restructuring have been designed. The next step will be to implement them.

\section{LOOKING AHEAD}

20. Overall, the Afghan authorities have made solid progress during the past $1 \frac{1}{2}$ years in improving economic management and achieving macroeconomic stability under very difficult circumstances. Looking ahead, to ensure fiscal sustainability, fiscal policy will need to focus on maintaining fiscal discipline; mobilizing domestic revenues (so that in a few years time the government's operating budget can be largely covered from domestic resources); moving ahead with civil service reform; and improving fiscal management in the provinces. The latter will require the continued compliance of provincial governors with their obligation to transfer revenues to the center. Monetary policy will need to continue to focus on maintaining low inflation by limiting monetary expansion within the present system of a (lightly managed) floating exchange rate regime. Once the economy has moved beyond the early structural changes inherent to the reconstruction process, the choice of exchange rate regime might be revisited. At the same time, the authorities must continue to push ahead forcefully with strong policy measures to create an environment conducive to sustainable private sector growth. This includes creating a market-oriented regulatory framework and a fair and functioning legal system, to firmly establish the rule of law and the security of property rights.

21. Of course, difficulties and risks remain in a number of areas. Restoring security throughout the country remains a key priority. To a large extent, this has been achieved for Kabul and its immediate surroundings with the help of the International Security Assistance Force (ISAF), but the government's control over many regional areas is still very limited. This situation complicates macroeconomic management and prevents reconstruction taking hold outside Kabul. An adequate level of security in the provinces needs to be established to permit the implementation of reforms and projects, as well as the resumption of private economic activity and the provision of basic public services, such as health care and education, in all rural areas. Without this, much of the country may become dominated by poppy cultivation and the production of opium, entering Afghanistan into a downward spiral of violence and corruption. 
22. Another risk is that external assistance may fall short of what is required. The experience of post-conflict countries shows that assistance typically starts to decline after a few years, just at the moment when the recipient country's capacity to absorb aid and use it effectively is increasing. Afghanistan's reconstruction effort has only just begun and will continue to require sizable assistance for several years to come. 


\section{Chapter II. ReCent MACRoeconomic Developments ${ }^{4}$}

\section{The Starting Point}

23. Afghanistan is a landlocked, mountainous, and arid country, with a wide ethnic diversity. Its population is estimated at about 22 million currently within its borders, and up to 25 million if all refugees were to return. Afghanistan's pre-war economy was mainly based on agriculture and animal husbandry, some light industry, and some natural resources (mainly gas and minerals). The country was largely self-sufficient in food and was even an exporter of agricultural products. Agriculture was largely concentrated in narrow river valleys and plains where irrigation water from snowmelt is available. Afghanistan experienced a modest degree of economic development until the late 1970s, when the country was still at peace. Modernization was largely concentrated in major cities and government services had limited reach in rural areas.

24. By the end of 2001, however, Afghanistan was a country ravaged by war and natural disasters. More than two decades of conflict, as well as droughts and earthquakes had resulted in widespread destruction and human suffering. Afghanistan's social and economic structures had been largely destroyed. Most of the country's infrastructure had been severely damaged and traditional irrigation systems had greatly suffered from destruction and lack of maintenance. Agricultural production had collapsed, livestock herds had been depleted, and industries had ceased functioning. Most skilled professionals had fled the country. Similarly dramatic was the breakdown of the state and civil society and the erosion of institutions, both modern and traditional. Government services, including health care and education, had essentially stopped functioning, resulting in a dramatic decline in social indicators, particularly affecting women (see Box II.1). In 1996, Afghanistan ranked $169^{\text {th }}$ out of 174 countries in the UN's Human Development Index and conditions deteriorated further in the following years. The health situation was grim. Infant and under-five mortality was estimated by UN agencies to be among the highest in the world in 2001 and malnutrition affected over 50 percent of children under age five. The average life expectancy was little more than 40 years.

25. A new opportunity for the peaceful development of Afghanistan emerged with the fall of the Taliban regime in late 2001 and the political agreement reached between the various Afghan factions in Bonn in December 2001. This chapter describes macroeconomic developments since then, as well as the main features of the country's external sector. The chapter starts out, with an overview of the large amounts of foreign assistance Afghanistan has received so far, and without which the country would not be where it is today. But it also puts this assistance in a broader perspective, comparing it to the levels of assistance received by other recent post-conflict cases.

\footnotetext{
${ }^{4}$ Prepared by Ron van Rooden and Louis Dicks-Mireaux.
} 


\section{Box II.1. Social Indicators}

Population (millions; 2002) 21.8

Life expectancy at birth (2001) $\quad 42.8$

Infant mortality per 1,000 live births (2001) 165

Under-five mortality per 1,000 live births (2001) 257

Children underweight (percent under age 5; 1995-2001) 48

Undernourished people (percent of population; 1998-2000) 70

Adult literacy (percent age 15 and above; 2001) 36

Male $\quad 51$

Female $\quad 21$

Primary school enrollment ratio, gross (in percent; 1995-99)

$\begin{array}{lc}\text { Male } & 53 \\ \text { Female } & 5\end{array}$

Population without sustainable access to an

improved water source (in percent; 2000) 87

Sources: Central Statistics Office of Afghanistan; UNDP, Human Development Indicators, 2003; UNICEF, The State of the World's Children, 2003; and World Bank, World Development Indicators, 2003.

\section{A COMPARISON OF DONOR ASSISTANCE}

26. Afghanistan's reconstruction would not be possible without strong support from the international community, including financial assistance. At a donor meeting in November 2001, the World Bank, the Asian Development Bank (AsDB), and the United Nations Development Program (UNDP) were asked to produce a preliminary needs assessment for Afghanistan's reconstruction. These agencies presented their findings at the International Conference on Reconstruction Assistance to Afghanistan held in Tokyo in January 2002. According to this assessment, $\$ 14.6$ billion would be needed over a period of 10 years in external assistance to support Afghanistan's economic and social recovery, excluding humanitarian assistance, with requirements for the first year estimated at $\$ 1.7$ billion and, for the first $2 \frac{1}{2}$ years, $\$ 4.9$ billion. This assessment was well received by donors and the Tokyo conference generated pledges totaling $\$ 4.5$ billion for the first 5 years, but with most of these covering the first $2 \frac{1}{2}$ years and $\$ 1.8$ billion in pledges for the first year (these amounts also include humanitarian assistance). Including some additional pledges made following the Tokyo conference, pledges for the first 15 months (covering 2002 and the first quarter of 2003 ) totaled $\$ 2.1$ billion in grants. During that period, virtually all of these pledges were committed and over $\$ 1.8$ billion in grants were actually disbursed, plus $\$ 0.1$ billion disbursed in loans. 
27. At a first glance, the size of disbursements appears to be well in line with the pledges made by donors and with the preliminary needs assessment. However, the needs assessment excluded humanitarian assistance, while the bulk of disbursements so far have been meet humanitarian needs. Aid flows geared toward reconstruction are only just beginning to gear up. To some extent, this pattern mirrors other recent post-conflict cases and fits reasonably well with the country's early needs and capacity. ${ }^{5}$ In a typical post-conflict case, donors first strive to address the immediate humanitarian emergency, providing shelter to displaced people and ensuring minimum levels of consumption to those unable to fend for themselves. This is followed by reconstruction aid, as donors aim to repair or rebuild the destroyed infrastructure and institutions, and restore the provision of basic public services that were disrupted by the conflict, such as security, health care, and education. The reconstruction aid typically takes longer to materialize, because it needs more preparation (feasibility studies, design, more complex procurement procedures, etc.) than humanitarian aid. Experience shows that early attention to critical elements of infrastructure (primary roads and telecommunication) and capacity building within the government is crucial to get the reconstruction process going. Over time, as the reconstruction process gets underway and institutions are restored, a country's capacity to absorb reconstruction aid will quickly increase. Donors and country authorities need to find the right balance between speed and capacity to effectively absorb aid. But a country will also need to beware of donor fatigue. As has been observed in other post-conflict cases, donor interest often declines sharply after a few years, just when a country's capacity to absorb reconstruction aid actually starts to increase significantly. In the case of Afghanistan, there is a risk that the decline in donor attention may happen even sooner, as other post-conflict cases compete for funds.

28. The level of foreign assistance Afghanistan has received so far appears to be on the low side compared to other recent post-conflict cases, particularly when looking at the level of aid per capita (Figure II.1). ${ }^{6}$ Using a population estimate of 22 million, the total amount of assistance Afghanistan received over the period January 2002-March 2003 translates into $\$ 67$ per capita per year. This is far less than Bosnia and Herzegovina, which received on average \$249 per capita per year in aid during 1995-97; Timor-Leste, which received \$256 per capita per year during 1999-01; and West Bank and Gaza, which received \$219 per capita per year during 1994-01. ${ }^{7}$ Rwanda, with $\$ 98$ per capita per year in aid during 1994-96, received far less than these other countries, but still more than Afghanistan did last year. One could argue that the price level in places like Bosnia and Herzegovina or West Bank and Gaza is much higher, so that $\$ 1$ in assistance "buys" less relief there than in Afghanistan. But this is only partly true, because many items, including foreign staff, are procured internationally. Moreover, the cost of transportation and providing adequate security to relief and reconstruction efforts appear to be at least equally high, if not higher, in the case of Afghanistan compared to other cases.

\footnotetext{
${ }^{5}$ See Demekas et al. (2002).

${ }^{6}$ This was first pointed out by CARE International 2002 (policy brief). See also Dobbins et al. (2003).

${ }^{7}$ Data from World Development Indicators (2003), World Bank.
} 
Figure II.1. Post-Conflict Countries: Comparison of Foreign Assistance

Aid per Capita

(In U.S. dollars; annual averages)

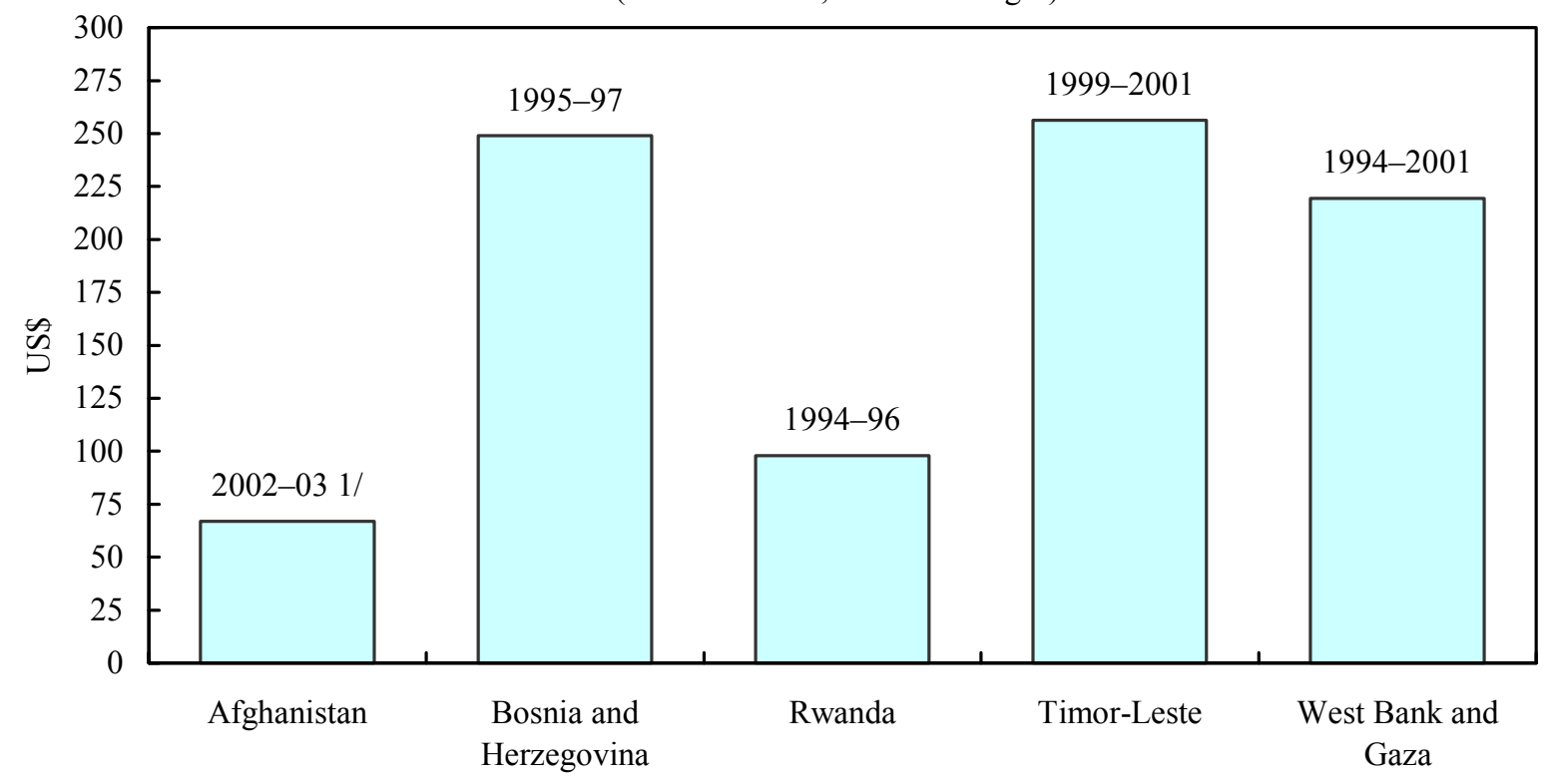

Aid in Percent of GDP

(Annual averages)

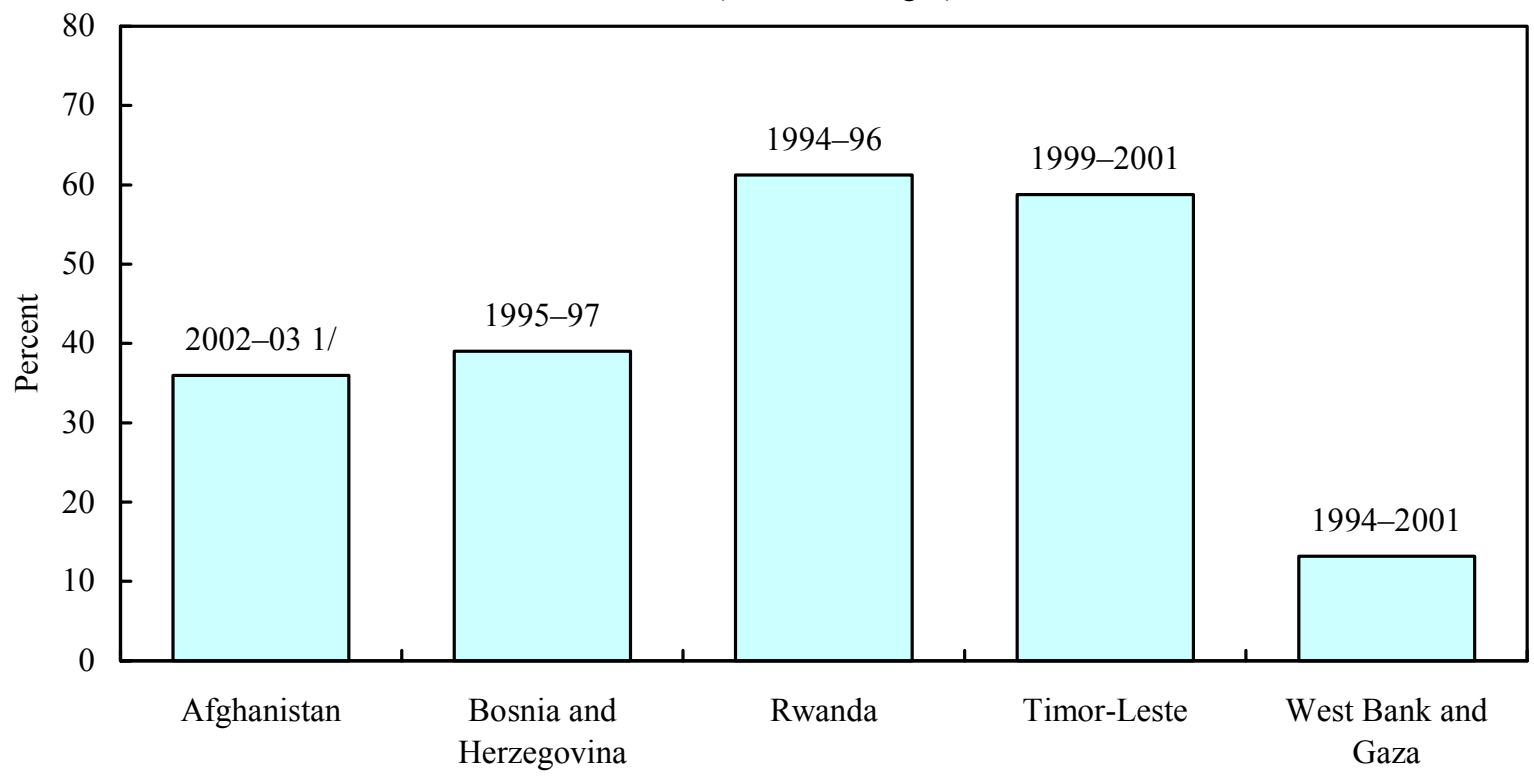

Sources: Afghan authorities; World Bank, World Development Indicators.

1/ January 2002-March 2003. 
29. An alternative approach is to compare levels of foreign assistance expressed in percent of (estimated) GDP. Of course, GDP estimates are highly uncertain, but based on available information, Afghanistan received close to 40 percent of GDP in aid in 2002/03, which is similar to Bosnia and Herzegovina during 1995-97, and much higher than the 13 percent West Bank and Gaza received during 1994-2001. On the other hand, aid to Afghanistan expressed in percent of GDP remains below the ratio for Timor-Leste and Rwanda, which both averaged about 60 percent per year during 1999-2001 and 1994-96, respectively. But one can argue that GDP may be low, and thus the ratio of aid-to-GDP high, because an economy has been largely destroyed. If so, bringing a country back to a level where it can successfully sustain itself will require high levels of assistance and most likely for a longer period of time. The latter is clearly the case in Afghanistan, where fighting has been going on for over 20 years and has destroyed much of the country's economic capital, both human and physical.

30. All in all, it does appear that, so far, aid flows to Afghanistan have been relatively low compared to other recent post-conflict cases. While disbursements have been high compared to pledged amounts, pledges may have been low compared to actual needs. Without continued and substantial foreign assistance over several years to come, Afghanistan will not be able to reach a level from which it can further develop on its own. Instead, Afghanistan could run the risk of becoming a country that remains dependent on foreign aid, with large parts of the population remaining poor. Or worse, the country could descend into a downward spiral of violence, criminal activity, and widespread corruption financed by the proceeds from opium production.

\section{OUtPut ANd Prices}

\section{On the road to recovery}

31. It should be stressed upfront that any analysis of economic developments continues to be very difficult as reliable statistics are still mostly unavailable. Most data presented here are rough estimates at best and should be interpreted as such. That said, the Afghan economy appears to have started on the road to recovery. This recovery has been driven by the international community's assistance and spending, as well as by a sharp rebound in agriculture following the end of a three-year drought. As the recovery started from extremely depressed levels of activity, a strong rebound was to be expected. Economic growth in 2002/03 is estimated by the Central Statistics Office of Afghanistan (CSO) to have reached almost 30 percent, based on indicators of agricultural production (excluding poppy production), construction (import and production of cement), and electricity production (Table II.1). According to the CSO, the start of the recovery brought 2002/03 GDP to a level of about $\$ 4$ billion, again excluding opium production. This GDP estimate was derived from the expenditure side, making crude assumptions regarding consumption, investment, and exports and imports. Using a population estimate of almost 22 million, this implies a per capita GDP of some \$180-190, still one of the lowest levels in the world. ${ }^{8}$

\footnotetext{
${ }^{8}$ For comparison, average per capita GDP in 2002 in Iran was \$1,610; Pakistan, \$446; Yemen, \$437; Sudan, \$418; Mauritania, \$355; and Ethiopia, \$89.
} 
Table II.1. Afghanistan: Gross Domestic Product, 2001/02-2002/03

(In millions of U.S. dollars, unless indicated otherwise)

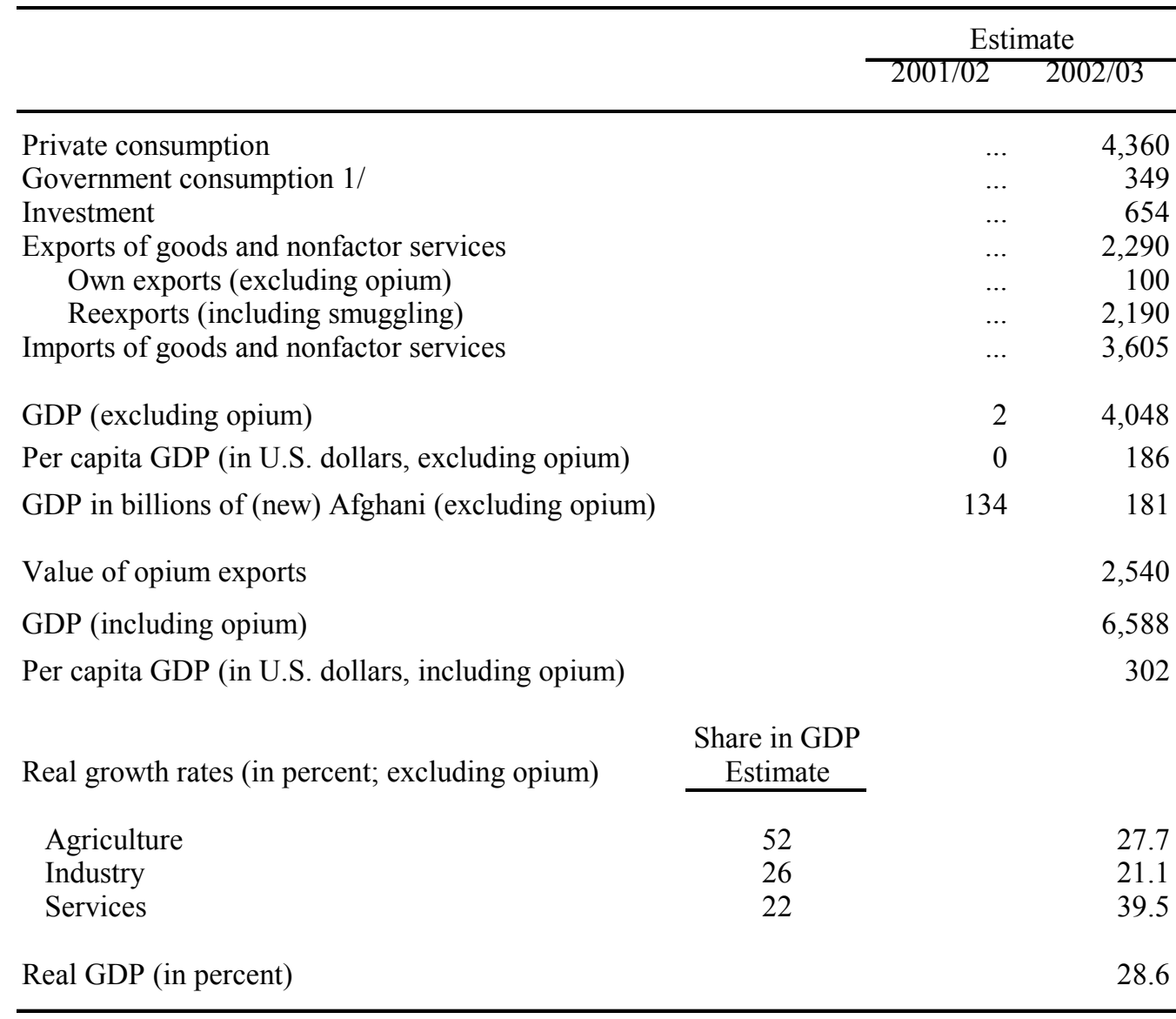

Sources: Central Statistics Office of Afghanistan; UNODC; and IMF staff estimates.

1 / Government spending from the operating budget.

32. The impact of international assistance is most visible in the services and construction sectors, which appear to be expanding rapidly, based on observations in cities, especially Kabul. The improvement in security and the large number of returning refugees also have helped promote economic growth. Many destroyed buildings have already been rebuilt or are under reconstruction. Returning refugees have tried to reclaim and rebuild their former homes. Retail trade has expanded significantly in the last 18 months, as has the number of taxicabs. Rush hour congestion in Kabul now resembles many cities in other countries. 
33. Although trade, services, and construction appear to be expanding rapidly, Afghanistan is still primarily an agricultural economy. The agricultural sector is estimated to support over three-quarters of the population and to account for over 50 percent of GDP. ${ }^{9}$ In $2002 / 03$, agriculture benefited not only from increased rainfall, but also from an increased availability and better quality of seeds, fertilizers, and other inputs. The Food and Agriculture Organization (FAO) and the World Food Program (WFP) estimated that total cereal production (mostly wheat) in 2002 was up by 80 percent, reaching 3.6 million metric tons, compared to 2 million metric tons in the preceding year (Table II.2). The production of fruits and vegetables, as well as of livestock-related products, such as dairy items, meat, wool, and hides, also increased. However, it will take longer for the production of these items to reach pre-conflict levels. The total livestock population in Afghanistan was largely depleted due to the many years of armed conflict and prolonged droughts, and the associated distress selling. Similarly, many orchards were cut down for firewood during harsh winters or destroyed during fighting.

Table II.2. Afghanistan: Selected Indicators of Economic Activity, 1999-2003

\begin{tabular}{lrrrrr}
\hline & 1999 & 2000 & 2001 & 2002 & 2003 \\
\hline Cereal production, total (metric tons) & $3,144,000$ & $1,763,000$ & $1,966,000$ & $3,589,000$ & $5,372,000$ \\
$\quad$ Percent change & -16.7 & -43.9 & 11.5 & 82.6 & 49.7 \\
Wheat & $2,500,000$ & $1,469,000$ & $1,597,000$ & $2,686,000$ & $4,361,000$ \\
Rice & 188,000 & 105,000 & 122,000 & 260,000 & 291,000 \\
Barley & 216,000 & 74,000 & 87,000 & 345,000 & 410,000 \\
Maize & 240,000 & 115,000 & 160,000 & 298,000 & 310,000 \\
Opium production (metric tons) & 4,565 & 3,276 & 185 & 3,422 & $\ldots$ \\
$\quad$ Percent change & 69.5 & -28.2 & -94.4 & $1,749.7$ & $\ldots$ \\
Electricity production (million kwh) & $\ldots$ & 503 & 490 & 557 & 13.8 \\
$\quad$ Percent change & $\ldots$ & $\ldots$ & -2.6 & $\ldots$ \\
Transport of goods by road (1,000 tons) & $\ldots$ & 1,887 & 3,688 & 5,015 & $\ldots$ \\
$\quad$ Percent change & $\ldots$ & $\ldots$ & 95.4 & 36.0 & $\ldots$ \\
Taxicabs & $\ldots$ & 16,991 & 19,209 & 33,507 & 74.4 \\
$\quad$ Percent change & $\ldots$ & $\ldots$ & 13.1 & $\ldots$ \\
\hline
\end{tabular}

Sources: FAO/WFP; UNODC; and CSO.

\footnotetext{
${ }^{9}$ This estimate is based on data for the early 1990s. The share of agriculture in Afghanistan's GDP may well be even larger, given the level of destruction of the country's infrastructure and industries.
} 
34. Agriculture is expected to expand again considerably in 2003/04. With continued snow and rainfall, cereal production increased by another 50 percent, reaching 5.4 million tons, the level Afghanistan needs to be self-sufficient. ${ }^{10}$ Contributing to this increase was the use of many land plots that were left unused during the drought. By putting virtually all of these plots back in use at the same time, cereal production has reached an upper limit within the current production capacity. Next year, many plots will need to be fallow before they can be planted again, which may result in a lower production level. With the continued strong growth in agriculture, as well as in services and construction, overall GDP is expected to grow by about 20 percent in $2003 / 04$.

35. Alleviating poverty in Afghanistan will require strong economic growth for many years to come. Donor inflows will continue to contribute to economic growth in the coming years, but sustained growth will require large amounts of investment. Further increases in agricultural production, for example, will require investment in (repairing) irrigation facilities. So far, investment in Afghanistan, apart from donor-funded projects such as road reconstruction, has been largely small-scale: rebuilding damaged stores, repairs on farms, or importing taxicabs. Large-scale private investment has been limited to telecommunications and, more recently, the (re)construction of hotels. A significant increase in large-scale private investment requires first and foremost adequate security, but also a market-oriented regulatory framework, a functioning and fair legal system, and a functioning banking system. In this context, a new investment law has been adopted and the authorities recently established an investment agency. The Afghan Investment Support Agency was opened in August 2003. Over the past year there has been a sharp increase in livestock licenses issued, reflecting a strong investment sentiment. Modern financial sector legislation is under preparation that will pave the way for the emergence of new commercial banks.

\section{A rebound in opium production}

36. Poppies have again become a major cash crop for Afghanistan. Although Afghanistan was not a traditional poppy growing country, the increasing lawlessness in large parts of the country during the many years of conflict, the high profitability of opium production, plus the fact that poppies flourish in the Afghan climate, had resulted in the country becoming the largest producer of illicit opium in the world by the mid-1990s. The Taliban introduced a ban on poppy cultivation in July 2000 that was brutally enforced. As a result, only very small quantities (185 tons) of opium were produced in 2001, mainly in the northern provinces, compared to over 3,000 tons in 2000. The new government that came to power in late 2001 also banned poppy cultivation, but the authorities' limited control over the provinces and favorable weather conditions, as well as rural poverty and lack of alternative livelihoods, have led to a sharp recovery in poppy production in 2002, yielding almost 3,500 tons of opium or 75 percent of the record 1999 harvest. Opium production is expected to have increased further in 2003.

\footnotetext{
${ }^{10}$ This does not automatically mean that Afghanistan would no longer require food assistance. While sufficient grains may be available, not every Afghan will have access to it. Many Afghans remain dependent on food aid.
} 
37. The impact of the poppy and opium sector on the economy is large. The value of opium exports (including derivatives like morphine and heroin) in 2002 is estimated by the United Nations Office on Drugs and Crime (UNODC) at about \$2.5 billion. This makes opium Afghanistan's largest source of export earnings. Accounting for opium exports in GDP estimates is complicated because estimates for private consumption and imports are likely to already reflect to some extent the proceeds from opium exports. Depending on these considerations, the share of opium in the economy could range from 40-60 percent. Estimates for GDP including opium could reach as high as $\$ 6.5$ billion. This high-end estimate would translate into a per capita GDP of $\$ 300$, but obviously this would not be spread evenly across the population. A more detailed description of poppy and opium production and trade can be found in the annex to this chapter.

\section{Toward low inflation}

38. Consumer prices in Afghanistan are very much influenced by exchange rate movements (Figure II.2). Price data are limited, but the CSO has maintained a consumer price index covering 50 main items, mostly food, for Kabul. Recently, this index was expanded to cover over 200 items, while the collection of price data is about to be expanded to cover major provincial cities as well. Domestic prices - and the exchange rate-fluctuated widely in late 2001 and the first few months of 2002, reflecting the rapidly changing political and economic conditions and large uncertainties (Table II.3). But as the new government started to steadily implement its economic policies and more goods became available, inflation came down quickly. Monthly inflation averaged 3.5 percent in the first 8 months of 2002. Uncertainty regarding the introduction of a new currency, however, caused the exchange rate to depreciate in the fall of 2002. ${ }^{11}$ This resulted in a sharp spike in prices. Consumer prices rose by a cumulative 60 percent during September-November 2002 and the 12 -month inflation rate reached almost 100 percent by end-2002. When the exchange rate strengthened in late 2002, prices came down as well. With the successful completion of the currency conversion process in early January 2003 and a relatively tight monetary policy, as well as an increased supply of major food staples, prices remained broadly stable in the first 8 months of 2003, with the average monthly inflation rate close to zero. As a result, the 12-month rate of inflation had fallen to 51 percent by August 2003.

\footnotetext{
${ }^{11}$ A new currency was introduced on October 7, 2002, with 1 new Afghani replacing 1,000 old ones. The conversion process ended on January 2, 2003. For more details, see Chapter V.
} 
Figure II.2. Afghanistan: Price and Exchange Rate Developments, 2001-03 1/

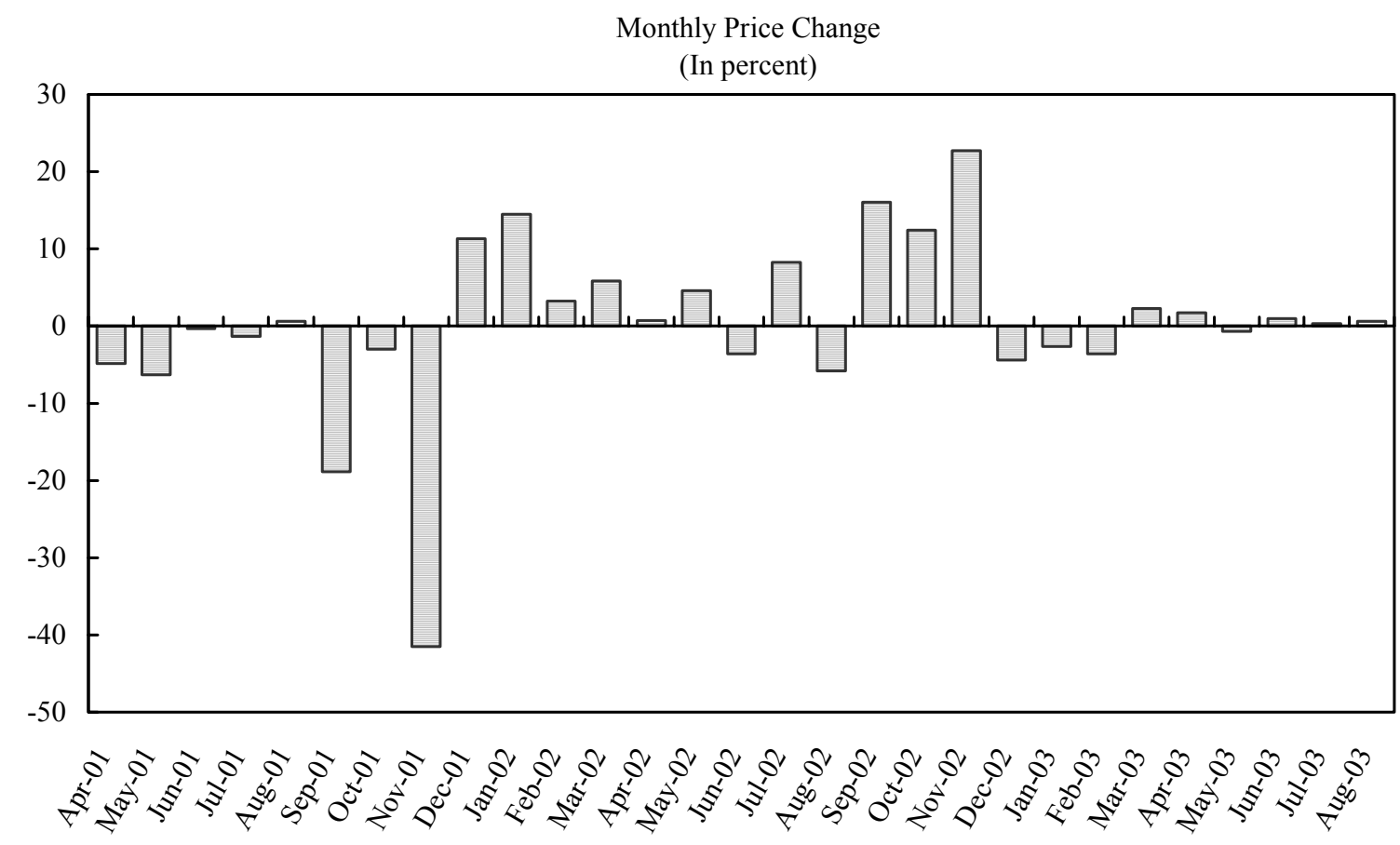

Price And Exchange Rate Indices
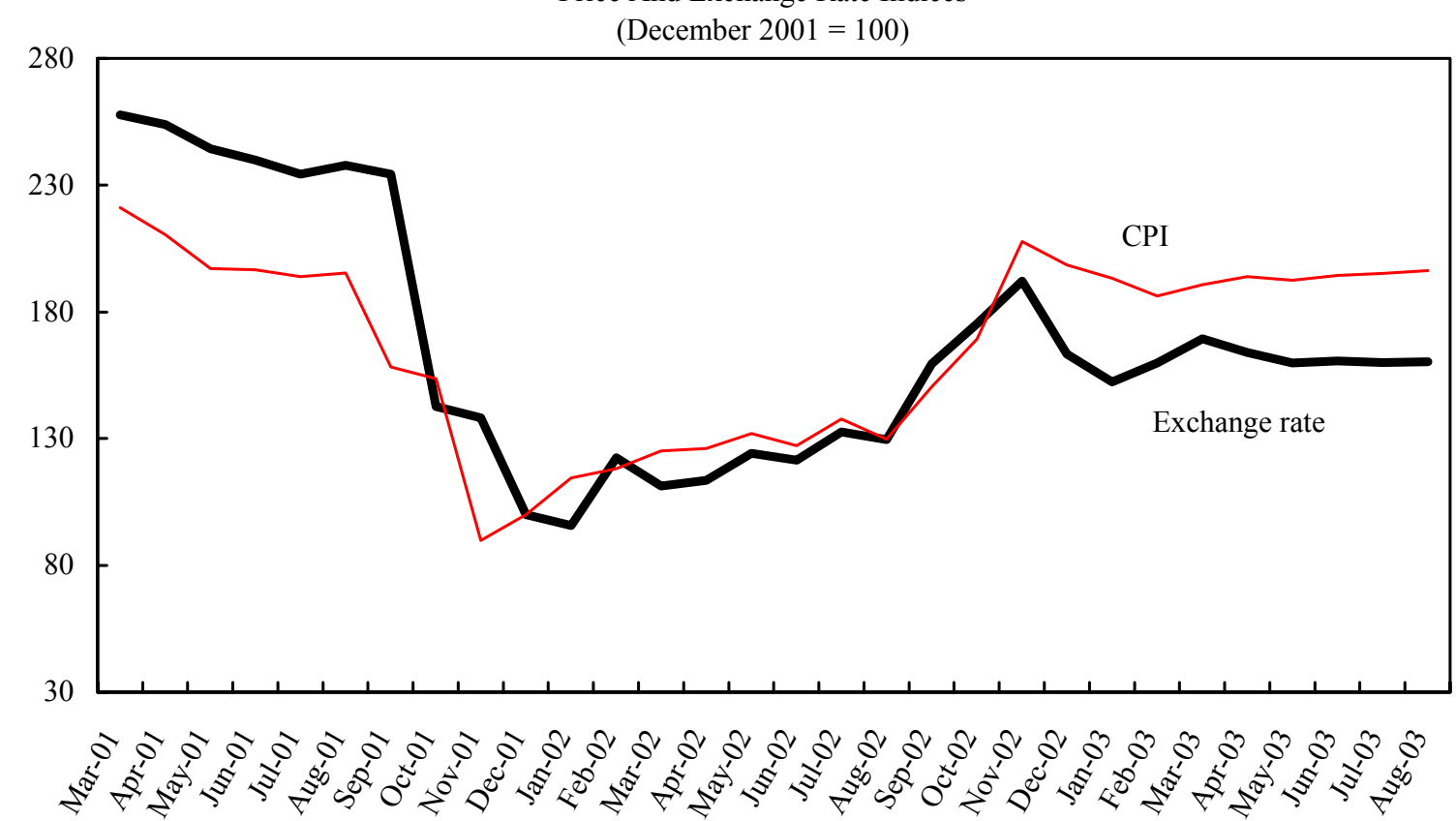

Sources: Central Statistics Office of Afghanistan; Da Afghanistan Bank.

1/ Last observation: August 2003. 
Table II.3. Afghanistan: Consumer Prices (Kabul), 2001-03

\begin{tabular}{|c|c|c|c|c|c|c|c|c|c|}
\hline & \multirow[t]{2}{*}{ Month } & \multicolumn{3}{|c|}{ Indices (Dec. $2002=100)$} & \multicolumn{3}{|c|}{ Monthly percentage changes } & \multirow{2}{*}{$\begin{array}{c}\text { Quarterly } \\
\text { percentage } \\
\text { changes }\end{array}$} & \multirow{2}{*}{$\begin{array}{l}\text { 12-month } \\
\text { percentage } \\
\text { changes }\end{array}$} \\
\hline & & General & Food & $\overline{\text { Nonfood }}$ & General & Food & $\overline{\text { Nonfood }}$ & & \\
\hline \multirow[t]{10}{*}{2001} & March & 111.4 & 118.1 & 99.5 & $\ldots$ & $\ldots$ & $\ldots$ & $\ldots$ & $\ldots$ \\
\hline & April & 106.0 & 110.3 & 98.5 & -4.8 & -6.6 & -1.1 & $\ldots$ & $\ldots$ \\
\hline & May & 99.3 & 101.4 & 95.7 & -6.3 & -8.0 & -2.8 & & $\ldots$ \\
\hline & June & 99.0 & 100.9 & 95.7 & -0.3 & -0.5 & 0.0 & -11.1 & $\ldots$ \\
\hline & July & 97.7 & 99.9 & 93.8 & -1.3 & -1.0 & -1.9 & $\ldots$ & $\ldots$ \\
\hline & August & 98.3 & 101.0 & 93.6 & 0.6 & 1.1 & -0.2 & $\ldots$ & $\ldots$ \\
\hline & September & 79.8 & 78.3 & 82.4 & -18.9 & -22.5 & -12.0 & -19.4 & $\ldots$ \\
\hline & October & 77.4 & 75.8 & 80.1 & -3.0 & -3.1 & -2.7 & $\ldots$ & $\ldots$ \\
\hline & November & 45.3 & 47.3 & 41.7 & -41.5 & -37.7 & -47.9 & $\ldots$ & $\ldots$ \\
\hline & December & 50.4 & 53.7 & 44.5 & 11.3 & 13.7 & 6.6 & -36.8 & $\ldots$ \\
\hline \multirow[t]{12}{*}{2002} & January & 57.7 & 62.6 & 49.0 & 14.5 & 16.5 & 10.2 & $\ldots$ & $\ldots$ \\
\hline & February & 59.6 & 65.4 & 49.2 & 3.3 & 4.5 & 0.5 & $\ldots$ & $\ldots$ \\
\hline & March & 63.1 & 65.4 & 58.9 & 5.9 & 0.0 & 19.7 & 25.2 & -43.4 \\
\hline & April & 63.5 & 66.1 & 59.0 & 0.7 & 1.0 & 0.3 & $\ldots$ & -40.1 \\
\hline & May & 66.4 & 69.6 & 60.9 & 4.6 & 5.3 & 3.2 & $\ldots$ & -33.1 \\
\hline & June & 64.1 & 66.5 & 59.8 & -3.6 & -4.5 & -1.8 & 1.6 & -35.3 \\
\hline & July & 69.4 & 74.0 & 61.2 & 8.3 & 11.3 & 2.3 & $\ldots$ & -29.0 \\
\hline & August & 65.3 & 67.1 & 62.3 & -5.8 & -9.3 & 1.7 & $\ldots$ & -33.6 \\
\hline & September & 75.8 & 78.5 & 71.0 & 16.0 & 17.1 & 14.0 & 18.3 & -4.9 \\
\hline & October & 85.2 & 85.9 & 84.1 & 12.4 & 9.4 & 18.4 & $\ldots$ & 10.2 \\
\hline & November & 104.6 & 108.7 & 97.4 & 22.7 & 26.5 & 15.9 & $\ldots$ & 131.1 \\
\hline & December & 100.0 & 100.0 & 100.0 & -4.4 & -8.0 & 2.7 & 31.9 & 98.5 \\
\hline \multirow[t]{8}{*}{2003} & January & 97.4 & 95.3 & 100.5 & -2.6 & -4.7 & 0.5 & $\ldots$ & 68.8 \\
\hline & February & 93.9 & 92.3 & 96.3 & -3.6 & -3.2 & -4.1 & $\ldots$ & 57.6 \\
\hline & March & 96.0 & 95.9 & 96.3 & 2.3 & 3.9 & -0.1 & -4.0 & 52.3 \\
\hline & April & 97.7 & 97.7 & 97.7 & 1.7 & 1.9 & 1.5 & $\ldots$ & 53.8 \\
\hline & May & 97.0 & 96.2 & 98.3 & -0.7 & -1.5 & 0.6 & $\ldots$ & 46.0 \\
\hline & June & 97.9 & 97.0 & 99.3 & 1.0 & 0.9 & 1.1 & 2.0 & 52.9 \\
\hline & July & 98.3 & 97.0 & 100.2 & 0.3 & 0.0 & 0.8 & $\ldots$ & 41.7 \\
\hline & August & 98.9 & 96.4 & 102.7 & 0.6 & -0.7 & 2.5 & $\ldots$ & 51.4 \\
\hline
\end{tabular}

Source: CSO. 


\section{THE EXTERNAL SECTOR}

\section{Balance of payments}

39. Estimating the balance of payments for Afghanistan is hampered by a severe lack of data. Estimates presented here are based on customs data to the extent available, partner country trade data, information supplied by international donors, and a trade survey conducted in 2000 by the UNDP and the World Bank. ${ }^{12}$ Customs data are believed to cover only two-thirds of total imports and only a fraction of exports because of smuggling. As such, while the broad structure and trends of the estimates are likely to be correct, the magnitude of the flows is subject to greater uncertainty than usual for a low-income country. Moreover, the figures do not include an estimate of opium exports which in 2002/03 were very large, in the order of $\$ 2.5$ billion (as discussed above and in the annex) equivalent to around half of GDP and roughly equal in value to estimated non-opium exports. When compared with Afghanistan's own non-opium exports (that is, excluding reexports) opium exports are the overwhelming source of export revenues generated with domestic resources. The balance of payments figures also exclude external flows related to the U.S. military operations and most of those related to the International Security Assistance Force (ISAF) activities for which there is no available information.

40. Overall, the balance of payments for 2002/03 is estimated to have shown a small surplus, after grants and donor assistance (Table II.4). The composition of the balance of payments and its evolution reflect in large part the donor-financed reconstruction effort and the revival of private sector activity. A large current account deficit (before grants) is funded mainly by official transfers; official loan disbursements were small.

41. Exports are expected to grow rapidly, although mostly in the form of re-exports. Own exports are a small fraction of Afghanistan's total exports; these include primarily agricultural products and have been boosted by the return of rains after several years of drought. Reexports comprise transit trade and "unofficial" (smuggling) exports. Transit trade is expected to increase steadily with the reopening of normal trade relations with transiting countries and the signing of new transit and trade agreements. The bulk of reexports are "unofficial" and are mainly to Pakistan; these exports are largely imported (officially and unofficially) via Iran. The demand in Pakistan for smuggled imports from Afghanistan arises because of the opportunity to avoid relatively high import tariffs and domestic sales taxes. Future growth in these unofficial reexports is expected to slow as the reform of customs administration becomes effective. The rapid growth of imports reflects both the revival of private sector activity and the more liberal environment - areas of particularly rapid growth in 2002/03 are cars, televisions, and refrigerators. Commodity food aid is expected to decline in 2003/04 with the rebound in domestic cereal production. Unrecorded imports comprise duty-exempt donor imports, transit trade, and smuggled goods.

${ }^{12}$ See World Bank (2001). 
Table II.4. Afghanistan: Balance of Payments, 2001/02-2002/03 1/

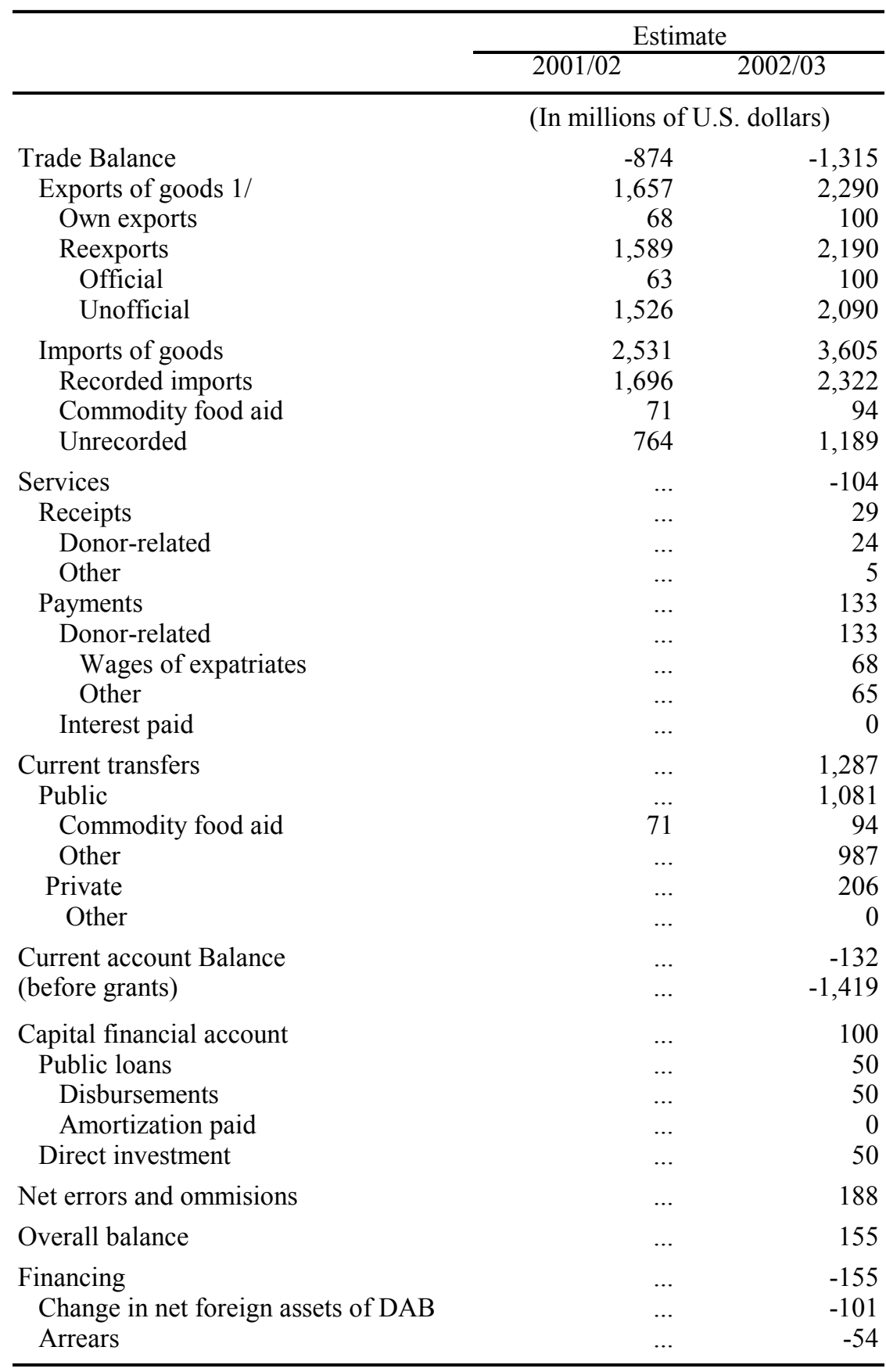

Source: Fund staff estimates.

1/ Excludes opium (and opium derivative) related exports which would imply a large trade surplus in 2002/03. These would be offset by opium related imports and other external payments, as well as the banking abroad of illicit earnings. The data also do not include flows associated with U.S. army and most ISAF activities. 
42. The bulk of service receipts and payments are a function of donor activities. Receipts comprise donor payments of local staff salaries, as well as expatriate accommodation and restaurant expenses. In addition, tourist travel and the local staff cost of ISAF and local expenditures of ISAF personnel are included. Payments comprise the payment of expatriate salaries, travel abroad, and the cost of embassies abroad. Interest payments on AsDB and the International Development Association (IDA) loans resumed in 2003/04. Current transfers are mainly official donor grants to fund the budget and national development plan. Private transfers include remittances from Afghans living abroad net of the remittance of expatriate salaries not spent domestically. Net errors and omissions are small and positive. While by its very nature the combination of flows captured in this term is unknown, it could reflect transactions related to military operations for which information is not available, and changes in the holdings of foreign currency by residents which may be significant given the cocirculation of, in particular, the U.S. dollar and Pakistani rupee in Afghanistan.

43. If opium (and opium derivative) related exports were to be included, the balance of payments would show a large surplus broadly equal in size to the additional opium exports. This surplus would be offset by an equally large additional errors and omissions outflow. The latter would be consistent with the banking abroad (and increase in foreign currency holdings within and outside Afghanistan) of illicit earnings related to opium, as well as with unrecorded imports likewise related, which have not been included in the estimates reported in Table II.4.

\section{The pattern and composition of trade}

44. Based on data from partner countries, Afghanistan's direction of export trade appears to have been relatively stable over the past five years. For imports the pattern has changed in recent years with the effects of reconstruction since 2001 emerging in 2002. Further changes in this respect are very likely. Partner country trade data and data from the CSO show similar patterns of exports but differ for imports (Tables II.5 and II.6). ${ }^{13}$ Export data cover official trade only and exclude a large amount of smuggled "unofficial" exports, primarily to Pakistan, which are imported officially and unofficially, largely across the Afghanistan-Iran border. The UNDP/World Bank survey of trade in 2000 estimated that out of total exports of about $\$ 1.2$ billion, about $\$ 1$ billion was unofficially exported. Exports to Iran and Pakistan account for about one-half of total exports, with Iran's share rising during 2001-02. Other export destinations that each account for 5 percent or more of exports are Belgium, Germany, Russia, the United Arab Emirates, and the United States. For imports, the source of one-third of imports is unclassified. In 2002, imports from Japan and the United States increased sharply reflecting the reconstruction and rejuvenation of the economy. Much of the increase

\footnotetext{
${ }^{13}$ The customs data, as reported by CSO data, differ from the Direction of Trade (DOT) data beginning 1999. For exports, CSO data show a slightly higher amount destined for Pakistan and India, which is reflected in a slightly higher value of total exports. For imports, the CSO data show much larger imports from Japan (with the discrepancy rising) and under unclassified.
} 
Table II.5. Afghanistan: Direction of Trade 1, 1997/98-2002/03

\begin{tabular}{|c|c|c|c|c|c|c|c|c|c|c|c|c|}
\hline & \multicolumn{6}{|c|}{ (In millions of U.S. dollars) } & \multicolumn{6}{|c|}{ (In percent of total value) } \\
\hline & $19 \overline{199 / 98}$ & $1998 / 99$ & $1999 / 2000$ & $2000 / 01$ & $2001 / 02$ & $\begin{array}{r}2002 / 03 \\
\text { Est. }\end{array}$ & $\overline{1997 / 98}$ & 1998/99 & $1999 / 2000$ & $2000 / 01$ & $2001 / 02$ & $\begin{array}{r}2002 / 03 \\
\text { Est. }\end{array}$ \\
\hline \multicolumn{13}{|l|}{ Exports } \\
\hline Total (official recorded only) & 144.4 & 150.3 & 166.0 & 137.0 & 68.0 & 100.0 & 100.0 & 100.0 & 100.0 & 100.0 & 100.0 & 100.0 \\
\hline 1. Pakistan & 29.8 & 25.4 & 71.0 & 52.0 & 26.0 & 26.0 & 20.6 & 16.9 & 42.8 & 38.0 & 38.2 & 26.0 \\
\hline 2. India & 3.2 & 21.6 & 13.0 & 8.0 & 10.0 & 27.4 & 2.2 & 14.4 & 7.8 & 5.8 & 14.7 & 27.4 \\
\hline 3. Belgium & 13.3 & 7.6 & 7.7 & 16.9 & 4.4 & 3.3 & 9.2 & 5.1 & 4.6 & 12.3 & 6.5 & 3.3 \\
\hline 4. United States & 10.2 & 16.0 & 8.4 & 2.6 & 0.6 & 4.3 & 7.0 & 10.6 & 5.0 & 1.9 & 0.9 & 4.3 \\
\hline 5. France & 10.5 & 24.7 & 1.3 & 0.3 & 0.4 & 0.2 & 7.3 & 16.5 & 0.8 & 0.2 & 0.6 & 0.2 \\
\hline 6. Germany & 9.4 & 6.8 & 5.7 & 5.1 & 6.6 & 5.5 & 6.5 & 4.5 & 3.4 & 3.7 & 9.6 & 5.5 \\
\hline 7. Finland & 4.4 & 5.4 & 24.0 & 1.0 & 6.3 & 9.0 & 3.0 & 3.6 & 14.5 & 0.7 & 9.3 & 9.0 \\
\hline 8. Russia & 7.5 & 6.5 & 5.8 & 4.9 & 2.5 & 3.5 & 5.2 & 4.3 & 3.5 & 3.6 & 3.7 & 3.5 \\
\hline 9. United Kingdom & 4.4 & 3.8 & 2.6 & 11.6 & 0.8 & 0.4 & 3.1 & 2.5 & 1.6 & 8.5 & 1.1 & 0.4 \\
\hline 10. United Arab Emirates & 2.7 & 3.6 & 3.6 & 4.5 & 4.8 & 4.6 & 1.9 & 2.4 & 2.2 & 3.3 & 7.1 & 4.6 \\
\hline 11. Unclassified & 49.2 & 28.9 & 23.0 & 30.1 & 5.6 & 15.9 & 34.0 & 19.2 & 13.8 & 21.9 & 8.2 & 15.9 \\
\hline \multicolumn{13}{|l|}{ Imports } \\
\hline Total (official recorded only; includes reexports) & s) 604.3 & 462.5 & $1,012.0$ & $1,176.0$ & $1,696.0$ & $2,322.0$ & 100.0 & 100.0 & 100.0 & 100.0 & 100.0 & 100.0 \\
\hline 1. Pakistan & 20.8 & 41.5 & 89.8 & 135.4 & 157.0 & 206.7 & 3.4 & 9.0 & 8.9 & 11.5 & 9.3 & 8.9 \\
\hline 2. Japan & 96.7 & 67.1 & 292.0 & 491.0 & 594.0 & 999.0 & 16.0 & 14.5 & 28.9 & 41.8 & 35.0 & 43.0 \\
\hline 3. Korea, Rep. of & 46.2 & 43.6 & 33.0 & 92.5 & 104.5 & 113.4 & 7.6 & 9.4 & 3.3 & 7.9 & 6.2 & 4.9 \\
\hline 4. Kenya & 38.3 & 38.8 & 41.0 & 47.2 & 52.1 & 56.5 & 6.3 & 8.4 & 4.1 & 4.0 & 3.1 & 2.4 \\
\hline 5. Turkmenistan & 23.0 & 22.4 & 45.0 & 41.8 & 46.2 & 50.1 & 3.8 & 4.9 & 4.4 & 3.6 & 2.7 & 2.2 \\
\hline 6. Singapore & 100.9 & 13.6 & 13.8 & 6.6 & 2.8 & 1.5 & 16.7 & 2.9 & 1.4 & 0.6 & 0.2 & 0.1 \\
\hline 7. India & 25.5 & 16.4 & 30.9 & 30.5 & 25.0 & 36.5 & 4.2 & 3.5 & 3.1 & 2.6 & 1.5 & 1.6 \\
\hline 8. China, People's Rep. of & 35.7 & 26.8 & 18.4 & 21.9 & 35.0 & 20.3 & 5.9 & 5.8 & 1.8 & 1.9 & 2.1 & 0.9 \\
\hline 9. Kazakhstan & 9.5 & 8.4 & 12.5 & 64.4 & 19.9 & 21.6 & 1.6 & 1.8 & 1.2 & 5.5 & 1.2 & 0.9 \\
\hline 10. Germany & 17.2 & 15.7 & 13.6 & 16.1 & 15.9 & 48.5 & 2.8 & 3.4 & 1.3 & 1.4 & 0.9 & 2.1 \\
\hline 11. Unclassified & 190.6 & 168.3 & 422.0 & 228.7 & 643.6 & 767.8 & 31.5 & 36.4 & 41.7 & 19.4 & 37.9 & 33.1 \\
\hline
\end{tabular}

Source: Central Statistics Office. 
Table II.6. Afghanistan: Direction of Trade 2, 1997-2002

\begin{tabular}{|c|c|c|c|c|c|c|c|c|c|c|c|c|}
\hline & \multicolumn{6}{|c|}{ (In millions of U.S dollars) } & \multicolumn{6}{|c|}{ (In percent of total value) } \\
\hline & 1997 & 1998 & 1999 & 2999 & 2001 & 2002 & 1997 & 1998 & 1999 & 2999 & 2001 & 2002 \\
\hline \multicolumn{13}{|l|}{ Imports } \\
\hline Total & 604.3 & 462.5 & 490.3 & 635.5 & 599.8 & 880.1 & 100.0 & 100.0 & 100.0 & 100.0 & 100.0 & 100.0 \\
\hline Japan & 96.7 & 67.1 & 72.7 & 56.9 & 49.4 & 84.9 & 16.0 & 14.5 & 14.8 & 8.9 & 8.2 & 9.7 \\
\hline Germany & 17.2 & 15.7 & 13.6 & 16.1 & 15.9 & 48.5 & 2.8 & 3.4 & 2.8 & 2.5 & 2.7 & 5.5 \\
\hline Kenya & 38.3 & 38.8 & 41.0 & 47.2 & 52.1 & 56.5 & 6.3 & 8.4 & 8.4 & 7.4 & 8.7 & 6.4 \\
\hline China, P.R. Mainland & 35.7 & 26.8 & 18.3 & 21.9 & 19.0 & 20.3 & 5.9 & 5.8 & 3.7 & 3.4 & 3.2 & 2.3 \\
\hline India & 25.4 & 16.4 & 30.9 & 30.5 & 33.7 & 36.5 & 4.2 & 3.5 & 6.3 & 4.8 & 5.6 & 4.2 \\
\hline $\operatorname{Iran} / 1$ & 14.5 & 3.8 & 11.8 & 39.7 & 36.5 & $\ldots$ & 2.4 & 0.8 & 2.4 & 6.3 & 6.1 & $\ldots$ \\
\hline Korea & 46.2 & 43.6 & 33.0 & 92.5 & 104.5 & 113.4 & 7.6 & 9.4 & 6.7 & 14.6 & 17.4 & 12.9 \\
\hline Pakistan & 20.7 & 41.5 & 89.8 & 135.4 & 157.0 & 206.7 & 3.4 & 9.0 & 18.3 & 21.3 & 26.2 & 23.5 \\
\hline Kazakhstan & 9.5 & 8.4 & 12.5 & 64.4 & 19.9 & 21.6 & 1.6 & 1.8 & 2.6 & 10.1 & 3.3 & 2.5 \\
\hline Russia & 20.6 & 14.9 & 14.6 & 12.3 & 8.5 & 26.0 & 3.4 & 3.2 & 3.0 & 1.9 & 1.4 & 3.0 \\
\hline Turkmenistan & 23.0 & 22.4 & 45.0 & 41.8 & 46.1 & 50.1 & 3.8 & 4.9 & 9.2 & 6.6 & 7.7 & 5.7 \\
\hline United States & 12.5 & 7.6 & 19.8 & 12.2 & 6.6 & 87.9 & 2.1 & 1.6 & 4.0 & 1.9 & 1.1 & 10.0 \\
\hline France & 20.0 & 14.0 & 7.0 & 6.2 & 5.2 & 10.2 & 3.3 & 3.0 & 1.4 & 1.0 & 0.9 & 1.2 \\
\hline Netherlands & 4.5 & 2.9 & 4.3 & 4.2 & 3.9 & 19.8 & 0.7 & 0.6 & 0.9 & 0.7 & 0.6 & 2.2 \\
\hline Rest of world & 12.4 & 16.8 & 14.1 & -12.2 & -8.5 & 44.5 & 2.0 & 3.6 & 2.9 & -1.9 & -1.4 & 5.1 \\
\hline \multicolumn{13}{|l|}{ Exports } \\
\hline Total & 144.4 & 150.3 & 122.0 & 145.8 & 94.3 & 96.9 & 100.0 & 100.0 & 100.0 & 100.0 & 100.0 & 100.0 \\
\hline United States & 10.2 & 16.0 & 8.4 & 2.6 & 0.6 & 4.3 & 7.1 & 10.6 & 6.9 & 1.8 & 0.7 & 4.4 \\
\hline Finland & 4.4 & 5.3 & 5.4 & 8.8 & 6.3 & 6.3 & 3.0 & 3.6 & 4.4 & 6.0 & 6.7 & 6.5 \\
\hline Germany & 9.4 & 6.8 & 5.7 & 5.1 & 6.6 & 5.5 & 6.5 & 4.5 & 4.7 & 3.5 & 7.0 & 5.7 \\
\hline India & 3.1 & 21.6 & 20.8 & 22.9 & 25.2 & 27.4 & 2.2 & 14.4 & 17.0 & 15.7 & 26.8 & 28.3 \\
\hline Iran 1/ & 3.3 & 0.1 & 0.4 & 1.1 & 0.7 & $\ldots$ & 2.3 & 0.1 & 0.4 & 0.7 & 0.8 & $\ldots$ \\
\hline Pakistan & 29.8 & 25.4 & 36.0 & 36.0 & 23.7 & 22.7 & 20.6 & 16.9 & 29.5 & 24.7 & 25.1 & 23.4 \\
\hline Russia & 7.5 & 6.5 & 5.8 & 4.9 & 2.5 & 3.5 & 5.2 & 4.3 & 4.8 & 3.4 & 2.7 & 3.6 \\
\hline United Arab Emirates & 2.7 & 3.6 & 3.6 & 4.5 & 4.8 & 4.6 & 1.9 & 2.4 & 3.0 & 3.1 & 5.1 & 4.7 \\
\hline Rest of world & 4.9 & 6.8 & 4.7 & 4.0 & 5.4 & 5.2 & 3.4 & 4.5 & 3.9 & 2.8 & 5.7 & 5.4 \\
\hline
\end{tabular}

Sources: Direction of Trade Statistics, IMF; and U.N. Statistics Division.

1/ Data for Iran is from U.N. 
is accounted for by cars, televisions, refrigerators, and other electrical appliances. The main origins of imports are Japan, Korea, and Pakistan, together accounting for about 40 percent of imports, of which most (in 2002) came from Japan. Other significant sources of imports, which in total account for about 15 percent of imports, are Germany, India, Iran, Kenya, Turkmenistan, and the United States. Most of Afghanistan's own exports are agricultural goods and carpets (Table II.7). On the import side, the major categories of goods are machinery and equipment, household items, fabrics and footwear, and food.

\section{Transit trade-A corridor for growth}

45. Afghanistan is dependent on other countries for access to the sea and to other markets. It is also a potentially important transit country for trade and higher volumes of transit trade could generate considerable revenues. Afghanistan provides access to the Indian Ocean and Pakistan for Central Asian countries, and also is a transit country for west-east trade. At present, most of Afghanistan's transit trade is with Iran and Pakistan, while transit trade with its northern neighbors was very limited during the Taliban period and continues to be small. Important obstacles to realizing Afghanistan's potential as a transit route, especially for its northern neighbors, are the poor quality of its transport infrastructure, poor security, and cumbersome border administration. For example, imports destined for Kabul and other eastern provinces from Iran are often routed through Uzbekistan rather than directly across the Iran-Afghanistan border, in order to by-pass a long stretch of travel in Afghanistan. This is motivated by the poor road conditions and frequent unofficial "tolls" charged by various factions in Afghanistan. To help overcome these obstacles to trade, several infrastructure improvements are underway, such as for the Kandahar-Kabul road, and more are in the pipeline. To improve conditions for transit trade, the Afghan authorities are renewing and improving existing transit trade agreements and establishing new ones with neighboring countries (see Box II.2). These would also be consistent with a number of regional initiatives, including improving regional trade amongst members of the Economic Cooperation Organization (ECO) under the existing ECO transit trade agreement. ${ }^{14}$

\section{Exchange and trade system}

46. During the late 1980s and early 1990s, Afghanistan had many official controls in the exchange system. Da Afghanistan Bank (DAB) maintained an official exchange rate (largely for government debt-service payments) and a commercial rate that was linked to the free rate in the money changers market on which the authorities did not impose any controls. This implied a multiple currency practice. Reflecting the orientation of trade, Afghanistan had bilateral payments agreements with Bulgaria, China, and the former Soviet Union, with settlement made in bilateral accounting U.S. dollars at rates set under the agreements. Outside of the payments agreements, foreign exchange proceeds from the main agricultural exports had to be surrendered immediately at the commercial rate. The bilateral payments

${ }^{14}$ ECO members comprise Afghanistan, Azerbaijan, Iran, Kazakhstan, Pakistan, Tajikistan, Turkey, Turkmenistan, and Uzbekistan. 
Table II.7. Afghanistan: Commodity Composition of Trade, 1997/98-2002/03

Exports

\begin{tabular}{|c|c|c|c|c|c|c|c|c|c|c|}
\hline & \multicolumn{5}{|c|}{ (In thousands of U.S. dollars) } & \multicolumn{5}{|c|}{ (In percent of total exports) } \\
\hline & $1997 / 98$ & $1998 / 99$ & $1999 / 2000$ & $2000 / 01$ & $2002 / 03$ & $1997 / 98$ & $1998 / 99$ & $1999 / 2000$ & $2000 / 01$ & $2002 / 03$ \\
\hline Total exports & 159,235 & 166,241 & 137,312 & 68,541 & 100,143 & 100.0 & 100.0 & 100.0 & 100.0 & 100.0 \\
\hline I. Fresh fruits & 9 & 5,797 & 8,403 & 4,269 & 5,587 & 0.0 & 3.5 & 6.1 & 6.2 & 5.6 \\
\hline II. Dried fruit & 2,919 & 9,282 & 16,381 & 23,328 & 40,582 & 1.8 & 5.6 & 11.9 & 34.0 & 40.5 \\
\hline III. Medicinal plants & 57 & 195 & 669 & 1,935 & 2,620 & 0.0 & 0.1 & 0.5 & 2.8 & 2.6 \\
\hline IV. Spices & 176 & 64 & 170 & 518 & 1,050 & 0.1 & 0.0 & 0.1 & 0.8 & 1.0 \\
\hline V. Seeds & 0 & 385 & 88 & 198 & 1,006 & 0.0 & 0.2 & 0.1 & 0.3 & 1.0 \\
\hline VI. Animal skins & 539 & 2,116 & 10,841 & 13,678 & 1,172 & 0.3 & 1.3 & 7.9 & 20.0 & 1.2 \\
\hline VII. Wool & 700 & 1,266 & 904 & 2,967 & 651 & 0.4 & 0.8 & 0.7 & 4.3 & 0.7 \\
\hline VIII. Sausages & 53 & 100 & 285 & 144 & 1 & 0.0 & 0.1 & 0.2 & 0.2 & 0.0 \\
\hline IX. Carpets, etc. & 154,782 & 147,036 & 99,571 & 21,503 & 47,474 & 97.2 & 88.4 & 72.5 & 31.4 & 47.4 \\
\hline
\end{tabular}


Table II.7. Afghanistan: Commodity Composition of Trade, 1997/98-2002/03 (concluded)

Imports

\begin{tabular}{|c|c|c|c|c|c|c|c|c|c|c|}
\hline & \multicolumn{5}{|c|}{ (In thousands of U.S. dollars) } & \multicolumn{5}{|c|}{ (In percent of total imports) } \\
\hline & $1997 / 98$ & $1998 / 99$ & $1999 / 2000$ & $2000 / 01$ & $2002 / 03$ & $1997 / 98$ & $1998 / 99$ & $1999 / 2000$ & $2000 / 01$ & $2002 / 03$ \\
\hline Total & 462,077 & $1,012,262$ & $1,175,896$ & $1,696,525$ & $2,322,609$ & 100.0 & 100.0 & 100.0 & 100.0 & 100.0 \\
\hline I. Machinary and equipment & 6,029 & 993,307 & 71,870 & 512,382 & 854,842 & 1.3 & 98.1 & 6.1 & 30.2 & 36.8 \\
\hline II. Petroleum, oil, etc. & 805 & 2,875 & 3,112 & 12,328 & 14,444 & 0.2 & 0.3 & 0.3 & 0.7 & 0.6 \\
\hline III. Metals & 446 & 648 & 5,077 & 3,557 & 6,751 & 0.1 & 0.1 & 0.4 & 0.2 & 0.3 \\
\hline IV. Chemical materials & 12 & 396 & 3,865 & 39,728 & 172,679 & 0.0 & 0.0 & 0.3 & 2.3 & 7.4 \\
\hline V. Construction materials & 96 & 1,303 & 536 & 4,276 & 48,420 & 0.0 & 0.1 & 0.0 & 0.3 & 2.1 \\
\hline VI. Paper & 0 & 40 & 45 & 48 & 59 & 0.0 & 0.0 & 0.0 & 0.0 & 0.0 \\
\hline VII. Clothing materials & 28 & 0 & 1,358 & 21,793 & 9,024 & 0.0 & 0.0 & 0.1 & 1.3 & 0.4 \\
\hline VIII. Food & 997 & 2,293 & 250,675 & 214,433 & 201,339 & 0.2 & 0.2 & 21.3 & 12.6 & 8.7 \\
\hline IX. Cigarettes and drinks & 110 & 335 & 3,727 & 23,111 & 46,636 & 0.0 & 0.0 & 0.3 & 1.4 & 2.0 \\
\hline X. Fabrics, clothing, and footwear & 1,747 & 905 & 478,521 & 472,638 & 345,934 & 0.4 & 0.1 & 40.7 & 27.9 & 14.9 \\
\hline XI. Household needs and medicine & 451,807 & 10,160 & 357,110 & 392,231 & 622,481 & 97.8 & 1.0 & 30.4 & 23.1 & 26.8 \\
\hline
\end{tabular}

Source: CSO 


\section{Box II.2. Trade, Transit, and Transport Agreements}

1. At present, the main transit trade agreement is with Pakistan for Afghanistan's imports and exports through Pakistan, largely to and from the southern port of Karachi and Port Quasim. This agreement was established in 1965, but during 1994-96 the Pakistan authorities had unilaterally banned several items from the eligible list; since 1996, 18 items have been banned. The ban was imposed because of concerns that a large part of these imports were being smuggled back into Pakistan. Following a series of meetings since 1991 between the two countries, the issues of disagreement are expected to be resolved by end-2003. Six of the banned items have recently been restored to the list and the time taken for processing and clearing procedures of transit goods has been reduced from 20 to 5 days. At the same time, it has been agreed that some categories of imports for which Afghanistan has little need and are clearly intended to be smuggled back into Pakistan will be eliminated from the eligible list. To reinforce this measure it is expected that Afghanistan will levy punitive import tariffs on these goods. Both countries are committed at a meeting later in the year to making substantial progress on lifting the ban on the remaining 12 restricted items. In addition, agreement was reached, with the support of aid from Pakistan, that the Torkham (the railhead in Pakistan) to Jalalabad (in Afghanistan) road would be repaired and a new road parallel to the existing one would be constructed by early 2005 .

2. Longstanding (since 1973) trade, transit, and transport agreements with Iran have been revised. A new transport agreement was signed in January 2003, and final approval of the trade and transit agreement was expected in mid-2003. Under these new agreements, changes included lifting previous restrictions on the routes that could be used by Afghanistan trucks between the border and destination cities and Afghan truckers were allowed to buy Iranian fuel at the same subsidized price as Iranian truckers. ${ }^{1 /}$ Discussions on trade and transit agreements have been initiated with Kyrgyzstan, Tajikistan, and Uzbekistan. In August 2003, a Memorandum of Understanding was signed by the Uzbekistan and Afghanistan authorities, and a draft agreement with Tajikistan is under discussion in order to establish mutually beneficial trade, transit, and railway development treaties.

3. In March, 2003, Afghanistan and India signed a new preferential trade agreement, which replaced an earlier one that was little used because of the Taliban presence and strained relations between India and Pakistan. Under the new agreement India has granted 50-100 percent tariff reductions on 38 export items from Afghanistan and duty-free access has been given to India for eight tariff lines. In June, 2002, preferential access to European markets was obtained under the Everything But Arms agreement, and in January, 2003, the United States granted Afghanistan GSP access to its domestic market. On April 10, 2003 Afghanistan applied for membership to the World Trade Organization.

4. Iran, India, and Afghanistan signed a Memorandum of Understanding in January, 2003, to improve access to the Iranian port of Chabahar on the Indian Ocean, along the Chabahar-Malik-Zaranj-Delaram route into Afghanistan. Under this understanding, Iran will build a new transit route to connect Milak in the southeast of Iran to Zaranj inside Afghanistan including the Milak bridge over Helmand river. ${ }^{2 /}$ For its part, India will build a new road connecting Zaranj to Delaram, which is on the main Herat-Kandahar road. These improvements will shorten the transit distance between Chabahar and Delaram by some 600-700 kilometers. Also, India and Iran will build a railroad from Chabahar to the Iranian Central railway station on the railroad between Karachi and Tehran (and further west), and Iran will extend its railway to port of Islam Qaleh. This would provide cheaper access to Chabahar and open up markets along the railroad and to Europe. In addition, Afghanistan was granted full access to the duty-free zone at the port of Chabahar. The Iranian authorities are also providing storage facilities and have permitted Afghan inspectors and trade representatives on-site. Port fees have been cut by 90 percent and warehousing and other charges by 50 percent; smaller cuts were granted for oil tankers.

1/ Previously, Afghan truckers had to pay the unsubsidized fuel price; the subsidy element is about 20 percent.

2/ At present, a main highway connects Chabahar and Malik (in Iran, south of Zaranj) with only a secondary road connecting to Zaranj. The bridge will shorten significantly the time taken to travel between Malik and Zaranj. 
agreements have now lapsed. There were some restrictions on invisible payments, primarily limits on foreign exchange cash to be taken abroad for personal travel, and foreign employees had to convert 60 percent of their foreign currency salaries into Afghanis at the official exchange rate. Foreign direct investment required prior approval and ownership could not exceed 49 percent. Capital could be repatriated only after five years and at annual rate of 20 percent of total registered capital.

47. In recent years, the exchange and trade system has radically changed and in effect is now very liberal and open (see Box II.3). Many of the rules and regulations that applied in the past are formally still in place, but in practice a liberal exchange and trade system is now being applied by the authorities. In any event, given the disrupted financial system, the erosion of capacity in customs and trade administration, and a relatively sophisticated Hawala system, controls would be difficult to enforce. More importantly, the authorities are committed to establishing a liberal and open exchange, payments, and trade systems. In order to formally achieve this and give a legal basis for the system, DAB intends to replace the existing set of rules and regulations for exchange and payments with new ones that conform with a liberal regime. For this purpose it has sought assistance from the IMF.

\section{Box II.3. Exchange and Trade Arrangements in Afghanistan}

1. Afghanistan now has a de facto unified exchange rate system. DAB quotes on a daily basis an official Afghani-U.S. dollar exchange rate based on the early morning rate in the free market of the money changers. ${ }^{1 /}$ This rate is used for all transactions including with the government. DAB exchange rates for other currencies are based on cross-rates with the U.S. dollar. DAB uses the buy and sell rate from the free market rather than applying a fixed spread around a central rate. During the first half of the year, the spread between the two rates (for cash transactions) has rarely exceeded 0.6 percent, while during the latter half of 2002 spreads were usually larger than in 2003 and on two occasions exceeded 2 percent. $^{2 /}$ In addition a small commission is charged on travelers checks and on international transfers. For transfers, fees are 0.25 percent of the amount, with a small minimum fee, and for letters of credits, fees are $0.25-0.5$ percent of the amount.

2. In practice, virtually no controls are enforced or are in place on imports and exports, payments, invisibles, and capital transactions. Traders (who for the most part carry out other domestic commercial activities and are thus classified and licensed as commercial businesses) are required to hold a commercial license, which is also required for all businesses; under this license exporting and importing is permitted, and no further export or import license is required. However, a few imports are subject to licenses and quotas. These comprise certain pharmaceutical products, mining items, and petroleum products for which a special license is required. The import of certain drugs, liquor, arms, ammunition is prohibited on grounds of public policy or for security reasons; special permission is required for these imports. Exports of opium and museum pieces are prohibited. Imports and exports should be registered with the Ministry of Commerce for recording and statistical purposes and to establish their eligibility for export incentives.

1/ Each morning, DAB calculates a simple average of the buy rate and the sell rate of ten reputable and large licensed money changers and quotes them as the official buy and sell rates. DAB quotes rates for cash and transfer transactions.

2/ The IMF considers a spread greater than 2 percent in official transaction to be a multiple currency practice. 
48. Under the existing customs regime, there are 25 customs import tariff bands with rates ranging from 7 percent to 150 percent allocated across 888 items. ${ }^{15}$ The majority of items fall within the $0-50$ percent range and the unweighted average tariff rate is 43.3 percent. The effective tariff rate is much lower because an undervalued exchange rate (Af 4.5 per U.S. dollar) is used to obtain the taxable value of imports. In addition, there is a Red Crescent fee of 2.5 percent and a withholding incomes tax of 4 percent. These two levies use different exchange rates for valuing the base on which the taxes are assessed. For exports and imports, a 4 or 2 percent withholding tax reclaimable against the income tax is levied. Customs procedures are not applied consistently across the customs houses. The authorities are reviewing a new simplified tariff regime which is expected to be in place this year and have embarked on a reform of customs administration (see Chapter IV).

49. In principle, the Chamber of Commerce is supposed to carry out the valuation of imports (which is to be used as the basis for customs tariffs charges) and charges a fee of 2.5 percent for nonmembers and 2 percent for members. The fee is assessed on the c.i.f value calculated using the customs exchange rate, which is much more depreciated than the market exchange rate, and as a result the effective fees are currently much lower. ${ }^{16}$ But in practice, only a small part of imports are valued by the Chamber and the majority of valuations are carried out by the customs houses, for which no fee is charged.

50. In the absence of functioning commercial banks, most trade financing is done by cash or through the Hawala system. The central bank did not open letters of credit in its own name before 2003. During the first half of 2003, it opened 15 letters of credit for government agencies under the World Bank Donor Flow Management Program. ${ }^{17}$ Earlier limits on the amounts that can be taken out of the country for tourist and business travel have been eased, limits on payments for medical treatment abroad are no longer enforced, nor is the requirement that foreign employees convert 60 percent of their foreign currency salaries into Afghani.

51. Foreign investment is required to conform to the new Domestic and Foreign Private Investment Law of 2002. Foreign and domestic investment require prior approval and investments in construction of pipelines, telecommunications, infrastructure, oil and gas, mines, and minerals are regulated under separate legislation. Full foreign participation is allowed and there are no limits on the transfer of capital and profits out of Afghanistan. The law provides tax holidays of up to seven years and a four-year exemption on export tariffs and duties. However, the Law is being reviewed with consideration being given to eliminate the tax holidays.

\footnotetext{
${ }^{15}$ See Chapter IV for a detailed description of the tariff structure and its application.

${ }^{16}$ Following the customs policy reform (see Chapter IV), customs valuation will use the market exchange rate.

${ }^{17}$ The World Bank provides a special commitment letter to the correspondent bank in which the World Bank commits to guarantee payments made under the letter of credit; this obviates the need for the usual advance collateral deposit.
} 


\section{Annex II.1. The Poppy Dimension in the Afghan Economy ${ }^{18}$}

52. Afghanistan is by far the largest producer of opium in the world, accounting for more than 70 percent of world supplies on average over the last decade according to the United Nations Office on Drugs and Crime (UNODC). ${ }^{19}$ Afghanistan, however was not a traditional opium exporting country. The cultivation of the poppy on a large scale is a relatively recent phenomenon, dating back to the early 1980s when strict bans on opium production introduced in Turkey, Iran, and Pakistan pushed up the world price of opium. At the same time, governments in Afghanistan were progressively losing control over rural areas. Faced with strong international demand and virtually no legal or social impediments, poppy cultivation flourished. It did not take long for Afghanistan to displace the so-called Golden Triangle (Thailand, Lao P.D.R., and Myanmar) as the main supplier of opiates to Europe and the Middle East.

53. The almost complete collapse of any form of central government after the Soviet withdrawal, the warring parties' needs for alternative sources of financing, and the fact that opium was a crop well adapted to the prevailing circumstances, greatly added momentum to this trend. Opium became firmly entrenched in the economy. While the annual rate of growth of opium production had been, on average, 14 percent per year between 1979 and 1989, it accelerated to 19 percent per year between 1989 and 1994. Afghanistan's share in world production grew accordingly from about 20 percent in 1980 to 50 percent in 1995, just prior to the Taliban takeover, and to 79 percent in $1999 .{ }^{20}$ Opium became the country's largest cash crop and its only significant source of (illicit) export earnings. Two decades of expanding Afghan production has contributed to the dramatic decline in the street price of heroin (in real terms) in Western Europe, which fell from the equivalent of about $\$ 300$ per gram (after adjusting for inflation) in 1987 to $\$ 70$ per gram in 2000.

54. In spite of the illicit nature of the opium economy, a wealth of information is available. This is mainly thanks to the dedicated work of the UNODC, which as part of its global Illicit Crop Monitoring Program (ICMP) operates a poppy crop monitoring system in Afghanistan, now in close cooperation with the new transitional government of Afghanistan. As part of this monitoring regular opium surveys are conducted that combine satellite imagery with cross-checking on the ground to produce a detailed mapping of poppy cultivation. The surveys are complemented by in-depth interviews with farmers and traders, the collection of comprehensive price data, and studies of seizure data in neighboring countries. The results are published annually, normally a few months after the end of the April-June harvest season, and supplemented by interim reports. Most of the analysis

\footnotetext{
${ }^{18}$ Prepared by Bruno de Schaetzen.

${ }^{19}$ For a detailed discussion of world illicit opiates markets, see United Nations International Drug Control Program (UNDCP; 2002b).

${ }^{20}$ UNDCP (2002b) and UNODC (2003).
} 
presented in this annex is based on information from the 2002 survey and some preliminary data for 2003. It is expected that the 2003 survey will be available in early October 2003.

\section{Growing production}

55. From 1994 to 2000, annual opium production is estimated to have averaged around 3,000 tons per year (Table AII.1). During this period, the acreage under cultivation fluctuated between about 53,800 hectares to 91,000 hectares. On average this represented less than one percent of the country's arable land. But yields per hectare in Afghanistan in the areas cultivated with poppy are on average more than three times higher than in Myanmar, the world's second largest producer. ${ }^{21}$ With virtually no restrictions on poppy growing at the time, year-on-year fluctuations reflected the normal pattern of an annual agricultural crop affected by changes in climatic conditions and the supply response to price changes, typically lagged one year. Production has been mainly concentrated in two provinces, Helmand (40 percent of total production in 2002) and Nangarhar (27 percent), but has been rising more rapidly in the north, particularly in Badagshan. ${ }^{22}$ These provinces have some of the most productive agricultural land in the country.

Table AII.1. Afghanistan: Indicators of Opium Cultivation, 1994-2002

\begin{tabular}{|c|c|c|c|c|c|c|c|c|c|}
\hline & 1994 & 1995 & 1996 & 1997 & 1998 & 1999 & 2000 & 2001 & 2002 \\
\hline Production (in metric tons) & 3,416 & 2,335 & 2,248 & 2,804 & 2,693 & 4,565 & 3,276 & 185 & 3,422 \\
\hline Cultivated aera (in ha after eradication) & 71,470 & 53,759 & 56,824 & 58,416 & 63,674 & 90,983 & 82,171 & 7,606 & 74,045 \\
\hline Yield per ha (in $\mathrm{kg}$ ) & 47.8 & 43.4 & 39.6 & 48.0 & 42.3 & 50.2 & 39.9 & 24.3 & 46.2 \\
\hline Average farm gate price at harvest time $(\$$ per $\mathrm{kg})$ & 30.0 & 23.0 & 24.0 & 33.7 & 32.8 & 40.1 & 27.8 & 301.0 & 350.7 \\
\hline Main bazaar prices (in $\$$ per kg) & 69.0 & 65.0 & 50.0 & 71.0 & 65.0 & 55.0 & 39.0 & 301.0 & 350.7 \\
\hline Gross income per ha (in \$) & $3,297.9$ & $2,823.2$ & $1,978.0$ & $3,408.0$ & $2,749.1$ & $2,759.6$ & $1,554.9$ & $7,321.2$ & $16,207.6$ \\
\hline Direct farm employement (in person year) & 77,205 & 58,073 & 61,384 & 63,104 & 68,784 & 98,284 & 88,765 & 8,216 & 79,987 \\
\hline Persons needed at harvest time (in persons) & 794,111 & 597,322 & 631,378 & 649,067 & 707,489 & $1,010,922$ & 913,011 & 84,511 & 822,722 \\
\hline
\end{tabular}

Source: UNODC.

56. Excess rain in 1998 caused crop damage during the harvest, and production sagged. In 1999, exceptionally favorable climatic conditions together with a rise of acreage under cultivation led to a record harvest of 4,565 tons. In September of that year the Taliban, in an effort to stave off looming international sanctions, ordered poppy growers to reduce their planting by one-third. Weakly enforced, this decree had little effect, although production was, in the event, reduced to 3,276 tons in 2000 because of a drought. In July 2000, now faced with the prospect of severe international repercussions, the Taliban issued a total ban

${ }^{21}$ UNDCP (2001a and 2002b).

${ }^{22}$ UNDCP (2002a). 
on poppy cultivation that was soon resolutely enforced. Virtually no poppies were planted in the region under their control. Production fell by 95 percent and only small quantities of opium were harvested in 2001, mainly in the northern provinces. The 2001 sowing season coincided with the collapse of the Taliban regime. The resulting power vacuum incited widespread replanting, and acreage under cultivation soon returned to the record levels of the late 1990s.

57. One of the first acts of the new Afghan Interim Administration (AIA) was to issue, on January 17, 2002, a decree forbidding all poppy cultivation and trading, although this was too late to prevent the sowing of poppies which had already taken place. An ambitious eradication campaign soon followed this decree together with efforts to provide alternative livelihoods to farmers. But the government's still weak authority over the provinces, and delays in donor assistance for alternative crops and farmer support, made progress difficult. With favorable climatic conditions, the 2002 harvest produced 3,422 tons, similar to the 2000 harvest. No official UNODC estimates are yet available on the size of the 2003 harvest. Preliminary indications suggest that areas under cultivation have remained extensive despite stepped-up eradication efforts. While there was progress in reducing planted acreage in traditional poppy growing areas, an interim UNODC survey has reported that this appears to have been offset by proliferation in other areas and by the tendency of farmers to plant poppies in increasingly remote and inaccessible places. ${ }^{23}$ As a result, cultivation was seen in several new districts for the first time. Overall, it is probable that the 2003 harvest could be of a similar order of magnitude to the 2000 and 2002 harvests or maybe slightly larger.

\section{Development of prices}

58. During each year the fluctuation in opium prices tends to follow a typical annual agricultural cycle, reaching a low during the harvest period (April to June) and then gradually rising until a few weeks before the next harvest period. As opium can easily be conserved for long periods, all market participants, including farmers, traders, and processing laboratories, have relied on stock building and depletion to help limit price fluctuations and stabilize incomes. ${ }^{24}$ In the complete absence of a working financial system, opium has also played a significant role in rural areas as a store of value. In remote locations it was often considered more liquid than any other assets, including foreign currency. There were strong incentives therefore, even for individuals normally not involved in the trade, to hold opium.

59. Until recently local opium markets were fragmented, with large price disparities persisting between producing regions. These price disparities reflected a combination of regional differences in the quality of opium and difficulties in arbitraging between regions during the civil war. Regional opium centers therefore tended to be oriented toward specific export routes with the local price level reflecting a specific route's costs and risks. Opium

\footnotetext{
${ }^{23}$ UNDCP (2003a).

${ }^{24}$ UNDCP (1998b).
} 
centers in the south turned to Iran and southern Pakistan (Baluchistan), those in the east to northern Pakistan (North West Frontier Province) and those in the north to Tajikistan and Central Asia. Prices generally were the lowest in areas with the tightest controls at the border. The last two years have seen a pronounced integration of regional markets as the reduction in factional fighting has made it easier for traders to exploit the best trading routes.

60. From 1994 to 2000 average farm gate prices (as monitored by UNODC at harvest time), have fluctuated between a low of $\$ 23$ per $\mathrm{kg}$ and a high of $\$ 40$ per $\mathrm{kg}$ (Table AII.1). With international demand for opium growing relatively steadily, price fluctuations have reflected mainly domestic supply factors. Downward pressures have also occurred when trafficking networks or laboratories in the region were dismantled, creating temporary gluts on the Afghan markets. By contrast, large-scale purchases by traders occasionally caused temporary spikes. Market expectations have also played an important role in price formation.

61. The Taliban ban started a sharp increase in opium bazaar prices, which by April 2001 had risen almost tenfold to $\$ 380$ per $\mathrm{kg}$, before peaking $\$ 700$ per $\mathrm{kg}$ just prior to September 11,2001 . In the following weeks prices crashed to $\$ 90$ per $\mathrm{kg}$, as stocks were quickly liquidated in anticipation of military operations. Prices recovered over the next few months and soon exceeded $\$ 400$ per kg. in reaction to the transitional government's January 2002 prohibition decree and expectations of substantial donor assistance to help enforce it. With the start of the eradication campaign in April 2002 prices rose further to a high of nearly $\$ 600$ and after a period of erratic fluctuations settled back after the 2002 harvest to around $\$ 400$ per $\mathrm{kg}$. There are indications that, by the end of the 2003 harvest, prices had fallen further.

\section{Farming the poppy: the incentives}

62. UNODC estimates that the number of farmers involved in cultivating opium has fluctuated in recent years about 200,000 households. They tend to be representative of the general farming population in their region with average land holdings of one and a half hectares, of which one-third is usually devoted to poppy growing. Cash earnings are the main reason why farmers plant poppies. But surveys have revealed that, until the recent tenfold increase in prices, returns were not irresistibly high compared to other cash crops and often fluctuated widely. With few restrictions on cultivation during the civil war period, markets were fairly competitive. Other crops can sometimes turn out to be more attractive. A UNODC study shows that, for example, for the 1998/99 season opium was by far the most profitable crop because of a combination of high prices, a bumper harvest, and poor yields and prices for competing crops. But this situation reversed in the next season of 1999/2000, when the return per hectare on several alternative crops, including, grapes, onion, black cumin, and other fruits comfortably exceeded that of opium. ${ }^{25}$

${ }^{25}$ UNODC (2003) and UNDCP (2003b). 
63. A number of other factors have also made opium well suited to the needs of farmers during the difficult years of the civil war, and provided at times stronger incentives to produce opium than mere cash returns. First, as discussed in more detail below, opium production is extremely labor intensive. UNODC surveys reported that this was an important consideration for farmers supporting a large household in relation to the size of their land holdings. Second, a poppy crop presents a number of technical advantages. It does not require as much attention to irrigation as, say, wheat. It is relatively weather resistant with a short growing season, giving it an advantage over a crop such as black cumin, which needs three years to come to maturity. The early harvest frees resources to harvest other crops later, and makes it even possible in semitropical areas to plant a second crop. Third, opium is easy to store, transport, and sell. The destruction of the transportation infrastructure in many areas has often made it virtually impossible for farmers to grow other cash crops in remote districts. Fourth, opium is currently the only crop against which farmers in Afghanistan can easily obtain credit, albeit at usurious rates. A 1999 UNODC study reports that over 60 percent of traders interviewed made advance purchases of opium well before the harvest. $^{26}$

64. As there is no reliable information on the actual price at which farmers sell their opium crop, it is difficult to accurately estimate the gross income they derive from it, but broad estimates can be constructed. Table AII. 2 shows the value of production valued at the prices monitored by the UNODC a few weeks before each harvest. The accuracy of this measure of farmers' income is compromised by two problems, however, each pulling in the opposite direction. On the one hand, many farmers sell their crop forward at a discount usually exceeding 50 percent of the harvest price. On the other hand, prices tend to be the lowest just before harvest time. Better-off farmers generally hold on to their production with the intention to gradually sell it in subsequent months in the expectation of higher prices.

Table AII.2. Afghanistan: Estimate of Farmers' Net Income from Opium, 1994-2002

\begin{tabular}{|c|c|c|c|c|c|c|c|c|c|}
\hline & 1994 & 1995 & 1996 & 1997 & 1998 & 1999 & 2000 & 2001 & 2002 \\
\hline & \multicolumn{9}{|c|}{ (In millions of U.S. dollars) } \\
\hline Gross revenue to farmers from opium production & 235.7 & 151.8 & 112.4 & 199.1 & 175.0 & 251.1 & 127.8 & 55.7 & $1,200.1$ \\
\hline Seed, fertilizers, tools, and other inputs & 2.9 & 2.2 & 2.3 & 2.3 & 2.5 & 3.6 & 3.3 & 0.3 & 3.0 \\
\hline Wage bill (itinerant laborers) & 47.1 & 30.4 & 22.5 & 39.8 & 35.0 & 50.2 & 25.6 & 11.1 & 240.0 \\
\hline Taxes and other payments ( 30 percnet of gross revenue) & 70.7 & 45.5 & 33.7 & 59.7 & 52.5 & 75.3 & 38.3 & 16.7 & 360.0 \\
\hline Bazaar traders margins ( 8 percent) & 18.9 & 12.1 & 9.0 & 15.9 & 14.0 & 20.1 & 10.2 & 4.5 & 96.0 \\
\hline Net income & 96.1 & 61.6 & 44.9 & 81.3 & 71.0 & 101.8 & 50.4 & 23.1 & 501.1 \\
\hline
\end{tabular}

Source: UNODC.

${ }^{26}$ UNDCP (1999a). 


\section{Farming the poppy: employment and know-how}

65. Opium is by far the most labor-intensive cash crop in Afghanistan. To cultivate and harvest one hectare of poppy requires, on average, about 350-person days. This compares with 41 person-days for wheat and 135 person-days for black cumin, the second most labor-intensive crop in the country. Even more significant, most of this labor is needed at harvest, which requires about 250 person-days per hectare. The majority of growers therefore have to rely on hired help, usually six to seven itinerant harvesters per hectare. They are normally paid in-kind, a share of the harvest that has varied between one-fifth and one-sixth. Because of this high labor requirement UNODC estimates that about one million persons are involved in the opium harvest every year. Since production is concentrated in two provinces, this has a very pronounced effect on local labor markets. Acute labor shortages have been reported at harvest time in poppy growing areas, with schools and colleges emptying and public works programs coming to a standstill due to lack of manpower.

66. Two further considerations are important to understand the role of labor in the development of the opium industry-skilled labor and itinerant workers. In the earlier years availability of qualified labor was a limiting factor in poppy cultivation. Lancing of poppies is a delicate task that requires experience and knowledge as it can greatly affect the final yield. As experience was acquired this constraint was progressively lifted and a vast pool of competent workers emerged. This human capital stock now undoubtedly gives Afghanistan a large comparative advantage relative to other potential producers. But it only makes eradication efforts more difficult. The need for an itinerant workforce has contributed, in turn, to the rapid propagation of poppy growing. Having acquired know-how to cultivate poppies and having established the necessary contacts to sell the opium that they usually receive as a payment, itinerant laborers, once back in their home village, started to experiment with opium production. As a result from the mid-1990s cultivation gradually expanded from the core areas of Helmand, Nangarhar, and Badakshan to neighboring districts and provinces. Consequently, according to UNODC, the number of poppy growing villages in Afghanistan rose from 2,008 to 6,645 villages over the 1994-2000 period. ${ }^{27}$

\section{Trading and commodity markets}

67. Traders are the essential link between opium produced in remote, nearly inaccessible Afghan villages and heroin sold on the streets of Europe. UNODC estimates that approximately 15,000 persons participate in the concentric trafficking circles that funnel opiates out of Afghanistan. It is much more difficult and dangerous to obtain information on this segment of the opium economy. But studies suggest the following: ${ }^{28}$

\footnotetext{
${ }^{27} \operatorname{UNDCP}(1999 \mathrm{~b}, 1999 \mathrm{c}, 2000 \mathrm{a}$, and 2000b ).

${ }^{28}$ UNDCP (1998b) and UNODC (2003).
} 
- $\quad$ On the outer rim are the itinerant farm gate buyers. They buy from farmers and push them to produce by providing advice and incentives such as credit. They are the most numerous traffickers and have a relatively small average turnover. Surveys have found that they generally received a longer formal education than the population average and it is not uncommon to find teachers and government workers among them. Indeed, respondents often cited the lack of alternative employment opportunities, for those who had received an intermediate level of formal education, as an important consideration for going into opium trafficking. They especially bemoaned the absence of government jobs paying living wages. Until recently profits from small-scale trading were not substantial in absolute terms, but were attractive in relation to alternative sources of income. This suggests that trading was competitive and that there was no significant risk premium.

- $\quad$ Further toward the center of trafficking circles are the shop owners in the regional opium bazaars. They either buy directly from farmers, from itinerant traders, or from other shopkeepers. They sell to local consumers, clandestine laboratories, wholesale traders, other shop owners, foreign traders, or anyone interested in taking a position in opium. They may pool resources and put together large shipments when the demand so requires. Opium bazaars, therefore, which in some areas had as many as 200 shops, effectively operated as thriving regional commodity exchanges where opium was openly and actively traded. Recent intervention by the authorities has greatly curbed these activities.

- $\quad$ Finally at the center of the opium trade are the bulk buyers or large-scale specialist traders who buy opium throughout the year and organize shipping to border areas or directly abroad, sometimes amounting to several tons. This is the backbone of the narcotics industry. It consists of a relatively small number of traders, often linked by family ties, and willing to commit substantial capital. They can reap phenomenally large rewards, but also face substantially higher risks. Until recently, these included shipments being stolen, ransomed, lost to interdiction, or deception, and the sometimes rapidly fluctuating price of opium. Not surprisingly, one way to reduce these risks was to collude with or pay protection money to those in power.

68. The biggest risk and therefore rewards are for moving opium across the borders. Large-scale trafficking by Afghan nationals has usually been limited to trade within Afghanistan and the country's immediate neighbors. Afghans do not generally participate in lucrative international trafficking. Specialized traders that are members of tribes living on both sides of the border often undertake the actual border crossings. The deeper those traders are able to get into the neighboring country, the higher the profit. Prices are highest in Iran, but the penalty associated with being intercepted with drugs in Iran is also far higher than in other countries neighboring Afghanistan. 


\section{Clandestine laboratories}

69. Data from border seizures in neighboring countries suggest that in recent years only about 30 percent of Afghan opium is exported raw, and that the remainder is transformed into either morphine base or heroin. UNODC estimates that out of a total production of 3,276 tons in 2000, 1,081 tons were exported as raw opium, 1,146 tons were transformed into base morphine, and 1,048 tons into heroin ${ }^{29}$. This is a relatively new development indicative of the maturing of the opium industry in Afghanistan.

70. Processing within Afghanistan began in the mid-1990s when laboratories moved from Pakistan into eastern Afghanistan and progressively multiplied in other border locations. This development appears to have been prompted by a more supportive environment for trafficking in Afghanistan, and the desire to lessen cost and risk by transporting less bulky and more easily concealed heroin, as well as the higher profit margins associated with heroin trade. It is difficult to obtain precise information on these activities but refining seems to take place typically in small to medium-scale laboratories producing about $10 \mathrm{~kg}$ a day of brown heroin. There are reports of a relatively small number of large-scale laboratories located in heavily defended strongholds becoming dominant in the industry and producing top quality heroin. This suggests a move toward vertical integration and growing capacity. One indication of rising processing capacity is that the domestic spread between opium prices and high quality heroin has fallen significantly from 1997 to 1999.

71. The large recent increase in the price of raw opium prices is likely to have been a strong incentive for laboratories to improve the efficiency of their processes. While it used to take $10 \mathrm{~kg}$ of raw opium to produce $1 \mathrm{~kg}$ of heroine efficiency gains have reportedly lowered the required input to as little as $6 \mathrm{~kg}$. Aside from raw opium the largest costs for producing heroin is that of the precursor chemical acetic anhydride. Since the mid-1990s a thriving market has developed in acetic anhydride, with imports reportedly coming from Europe and Russia, often via Turkmenistan. Its average cost has fallen by two-thirds in Afghanistan since then, and has fluctuated in recent years between $\$ 15$ per liter and $\$ 36$ per liter.

Approximately four liters are needed to produce one kilo of heroin. One of the first steps of the new authorities at the start of their interdiction campaign was to close several bazaars where precursor chemicals were traded.

\section{Taxes and other levies on opium}

72. The legal or de facto rulers of the areas in which opium was cultivated or through which it transited have also likely benefited from the opiate industry. These may have included, at various times and places, warlords, local commanders, provincial administrators, tribal leaders, and even the central government until the fall of the Taliban regime. Opium is believed to have played an important role in financing the war against the Soviet occupation, and thereafter the civil war, either indirectly through levies on producers and traders, or

${ }^{29}$ UNDCP (2001b) and UNODC (2003). 
directly through the active and personal involvement of those in power. Taxes levied on opium by local authorities have also helped to strengthen the power of the regions over the center, and thereby reinforced the process that was at the origin of the opium economy. Surveys report that most farmers continued to dutifully pay the traditional agricultural taxes. Acceptance of this payment by the local authorities was often interpreted by the farmers and itinerant workers as implicit support for the cultivation of opium. Small-scale and bazaar traders have also indicated that they regularly paid taxes on their income.

\section{Exports of opium and its derivatives}

73. UNODC estimates for export volume and prices of raw opium, morphine, and heroin are only available for 2000 and there is no breakdown between heroin and morphine for 2002. In Table AII.3, it is assumed heroin and morphine were exported in 2002 in the same proportions as in 2000. No figures are available at all for 2001 as the Taliban ban, the disarray resulting from the collapse of their regime, and the unsettled security situation made it impossible to obtain meaningful estimates for that year. It is likely, however that exports were substantially higher than the small quantities produced because stocks accumulated in earlier years were likely to have been liquidated.

Table AII.3. Afghanistan: Revenues from Opiates, 2000-02

(In millions of U.S. dollars, unless otherwise indicated)

\begin{tabular}{lrrr}
\hline & 2000 & 2001 & 2002 \\
& & & \\
\hline I. Farmers & & & \\
Gross revenue to farmers from opium production & 127.8 & 55.7 & $1,200.0$ \\
Volume (in tons) & 3,276 & 185 & 3,422 \\
Price (\$ per kg, bazaar price) & 39.0 & 301.0 & 350.7 \\
a. Seed, fertilizers, tools, and other inputs & 3.3 & 0.3 & 3.0 \\
b. Wage bill (itinerant laborers) & 25.6 & 11.1 & 240.0 \\
c. Taxes and other payments (30 percent of gross revenue) & 38.3 & 16.7 & 360.0 \\
d. Bazaar and small traders margin (8 percent of gross revenues) & 10.2 & 4.5 & 96.0 \\
e. Surplus to farmers & 50.4 & 23.1 & 501.0 \\
& & & \\
II. Traders & & $\ldots$ & $1,359.0$ \\
1. Gross revenue from exporting raw opium & 425.0 & $\ldots 90$ \\
Volume (in tons) & $1,081.0$ & $\ldots$ & 890 \\
Price (\$ per kg) & 393.2 & $\ldots$ & $1,527.0$ \\
2. Gross revenue from exporting morphine & 175.0 & $\ldots$ & 651.2 \\
Volume (in tons) & 115.0 & $\ldots$ & 164.0 \\
Price (\$ per kg) & $1,521.7$ & $\ldots$ & $3,969.9$ \\
3. Gross revenue from exporting heroin & 245.0 & $\ldots$ & 529.8 \\
Volume (in tons) & 105.0 & $\ldots$ & 89.0 \\
Price (\$ per kg) & $2,333.3$ & $\ldots$ & $5,954.9$ \\
4. Total exports & 845.0 & $\ldots$ & $2,540.0$ \\
Volume (in tons) & $1,301.0$ & $\ldots$ & $1,143.0$ \\
Price (\$ per kg) & 649.5 & $\ldots$ & $2,222.2$ \\
\hline
\end{tabular}


74. These estimates suggest that the value of opium exports and opium derivatives increased substantially in 2002, in comparison to 2000 to a total of $\$ 2.5$ billion, mainly on account of higher prices. Of this, half relates to exports of raw opium and the remainder relates to exports of morphine and heroin, in roughly equal amounts. These estimates suggest that opium production would represent somewhere between 40-60 percent of Afghanistan's GDP, depending on the measure of non-opium GDP (itself subject to uncertainty) and is roughly equal in value to Afghanistan's legitimate (mostly transit) trade (see Chapter II).

75. The estimates also suggest that about half the income from opium exports probably accrues to farmers. This income is also likely to be mostly either spent or saved domestically. The other half of the gross export earnings of opiates would then accrue to refiners and traders after payment to farmers. These agents are probably better connected and bank their profits abroad. While these estimates provide an indication of the probable magnitude of revenue accruing to Afghanistan, they do not represent the value that exports of Afghan opiates fetch on the world market. The latter is probably substantially more than 10 times the value that Afghan exports of opiates fetch at the border. ${ }^{30}$ Most of the money made from trading Afghan opiates is therefore earned by international dealers and traffickers.

\section{Conclusion}

76. As the foregoing analysis makes clear, the rise of the opium economy is a relatively recent phenomenon that has occurred only over the last twenty years. The long-term failure of the Afghan state and its institutions, the breakdown of law and order, the degradation of agriculture, the absence of commerce or any alternative economic opportunity, and the destruction of infrastructure, made poppy cultivation one of the few viable economic activities in many areas of Afghanistan. This foundation was progressively built upon by raising productivity, by developing a qualified labor force, by expanding trade routes, and by investing in laboratories. A large number of stakeholders now have vested interests in the survival of this industry.

77. Reversing this process will require a substantial and prolonged commitment by the authorities and by the international community. This commitment will have to go beyond efforts at eradication and law enforcement. It will also demand a comprehensive strategy for building a stable and unified Afghan state, and for the development of a growing economy that provides alternative livelihoods throughout the country. Absent early and visible progress in these areas, a dangerous potential exists for Afghanistan to progressively slide into a narco-state where all legitimate institutions become penetrated by the power and wealth of traffickers.

\footnotetext{
${ }^{30}$ UNODC estimate that in Europe alone more than \$20 billion was spent on Afghan opiates.
} 


\section{References}

CARE International, 2002, Rebuilding Afghanistan: A Little Less talk, a Lot More Action, (policy brief, October; London).

Demekas, Dimitri G., Kosma, Theodora, and Jimmy McHugh, 2002, "The Economics of Post Conflict Aid," IMF Working Paper 02/198 (Washington: International Monetary Fund).

Dobbins, James, et al., 2003, America's Role in Nation-Building: from Germany to Iraq (Rand Corporation).

World Bank, 2001, Afghanistan's International Trade Relations with Neighboring Countries (Washington).

United Nations International Drug Control Program (UNDCP), 1998a, Afghanistan Strategic Studies \#1, An Analysis of the Process of Expansionof Opium Poppy Cultivation to new Districts in Afghanistan, (June).

, 1998b, Afghanistan Strategic Studies \# 2, The Dynamics of the Farmgate Opium Trade and the Coping Strategies of Opium Traders, (October).

, 1999a, Afghanistan Strategic Studies \# 3, The role of Opium as a Source of Informal Credit, (January).

, 1999b, Afghanistan Strategic Studies \#4, Access to Labor: The role of Opium in the Livelihood Strategies of itinerant Harvesters working in Helmand Provinces, (June).

, 1999c, Afghanistan, Strategic Study \#5, An Analysis of the Process of Expansion of Opium Poppy to New Districts in Afghanistan, Second Report, (November).

,2000a, Afghanistan, Opium Poppy Survey.

,2000b, Afghanistan, Strategic Study \#7, An analysis of the Process of Expansion of Opium to New Districts in Afghanistan, Final Report, (November).

, 2001a, Global Illicit Drug Trends.

, 2001b, Afghanistan, Annual Poppy Survey.

, 2002a, Afghanistan, Opium Survey 2002, (October)

, 2002b, Global Illicit Drug Trends.

, 2003a, Afghanistan, Opium Rapid Assessment Survey.

, 2003b, Afghanistan, Strategic Study \#9, Opium Poppy Cultivation in a Changing Policy Environment. Farmers' Intentions for the 2002/203 Growing Seasons.

United Nations Office on Drugs and Crime (UNODC), 2003, The Opium Economy in Afghanistan. An International Problem, (2nd ed.). 


\section{Chapter III. The Fiscal Framework ANd the Budget ${ }^{31}$}

\section{Overview of Past Fiscal Developments: A Slow Descent Into Chaos}

78. Very limited information is available on Afghanistan's fiscal situation before the Afghan Interim Administration (AIA) took office in December 2001. The last time fiscal developments in Afghanistan were analyzed was during the 1991 Article IV consultations between Afghanistan and the IMF, which covered the 1987-90 fiscal years and provided preliminary projections for the 1991 budget. There is no comprehensive source for fiscal data in the subsequent periods, including the civil war (1992-96) and the Taliban regime (19962001).

79. Partial information and empirical evidence confirm however, that after two decades of conflict, fiscal policy and public finance management had disintegrated. With continuous fighting and deteriorating economic conditions, traditional domestic revenues steadily declined together with inflows of external assistance, and were progressively replaced by illegal off-budget revenues, collected both by the central government and local warlords. Actual revenue performance continually fell short of budget requirements and the central bank provided the government with unlimited overdraft facilities to cover the resulting budget deficits. ${ }^{32}$ Monetization of the budget deficits resulted in high inflation and a rapid depreciation of the Afghani. ${ }^{33}$ For most of this period, budget spending was focused on security expenditures and payment of government salaries, with very limited amounts allocated to reconstruction and development. In sum, the national budget became a residual instrument in public policies, which were mainly conducted - and illegally financed-by warring local leaders according to their own factional interests.

80. The collapse of fiscal management and policy over the past twenty years took place in three stages. Traditionally, before the period of conflict began, government revenues were derived from three main sources: (a) extraction and exportation of mineral resources, particularly gas; (b) income transfers by state-owned enterprises (SOEs), whose production mostly focused on cement, fabric (especially wool), fertilizer, and agricultural goods; and (c) customs duties, taxes levied on agricultural land, hotels, residential dwellings, and sales tax on real estates and cars. These domestic revenues were substantially supplemented by grants and external borrowing from diverse sources.

\footnotetext{
${ }^{31}$ Prepared by Thierry Kalfon.

${ }^{32}$ At the end of 2001, the government's accumulated overdraft with Da Afghanistan Bank (DAB) was estimated by DAB to have reached almost (old) Af 15 trillion, equivalent to $\$ 300$ million at mid-2003 exchange rates.

33 The Central Statistics Office (CSO) released a report in 1996 showing that the prices of basic goods-such as flour, sugar, and cooking oil-rose on average about 162 times between 1991 and 1995 in Kabul.
} 
81. With the communist coup in April 1978, the new government sought to impose unpopular reforms, including land redistribution, and there was widespread unrest. This led to the invasion by the former Soviet Union in December 1979, and with the ten years of conflict that followed, the government's traditional revenue sources began to dry up. Fiscal management by the Soviet-supported communist government in Afghanistan relied heavily on the printing press and on Soviet financing.

82. Following the retreat of the Soviet troops, and the subsequent fragmentation of political authority and civil war between opposing military factions, provincial warlords gained control of the mineral and productive resources in their territories, diverting the associated revenues from central government to themselves, and started collecting large amounts of off-budget taxes and fees. Natural gas exports stopped, foreign assistance inflows substantially decreased, and the income of SOEs declined sharply due to large-scale armed confrontations in industrial areas, resulting in a severe loss of revenue for the central government. ${ }^{34}$ Despite this fall in revenue, expenditures increased significantly, reflecting rising defense spending, successive pay increases for government employees, and subsidies, mainly on food and utilities. The resulting deficits were covered entirely by printing money.

83. After it took power, the Taliban regime (1996-2001) is reported to have initially succeeded in collecting sizeable revenues from import duties on trade, agricultural taxes, municipality surcharges, and various fees on transportation. The tax revenue base was also broadened to include some Islamic taxes, such as zakat (wealth tax) and ushr (tax on agricultural products). In the first years of their administration, the Taliban also received foreign assistance from Pakistan (about \$10 million in 1998) and Saudi Arabia; the latter providing subsidized fuel and direct grants. ${ }^{35}$ In addition to these official revenues and grants, the regime benefited substantially from unofficial off-budget revenues from taxes on poppy cultivation and duties on opium exports, and on smuggling of consumer goods from the United Arab Emirates to Pakistan. In northeast Afghanistan, controlled by opposition movements to the Taliban, the main source of income came from the gem trade (lapis lazuli and emeralds) through collection of ushr on mine owners and zakat on traders. But by the end of the 1990s, the misrule and increased isolation of the Taliban regime, together with four years of drought and continued fighting, had seriously hampered the collection of official domestic revenues, and the government increasingly returned to monetary financing of the budget deficit.

\footnotetext{
34 In 1991, the ratio of revenues to estimated Net Material Product fell to 3 percent (IMF staff estimates).

35 Until the summer 1998 when this aid was stopped to protest against the Taliban's refusal to expel Oussama Bin Laden. Source: Rubin (2000).
} 


\section{The Starting Point: A Dismal Situation But Resilient Structures}

84. In December 2001, when the AIA took office, the Ministry of Finance (MoF) at the center and its provincial offices (Mustufiats) had, for most intents and purposes, ceased to function.

- Most of the skilled and qualified staff of the MoF has emigrated during the war. Except for a limited number of senior staff who returned to Kabul after the conflict, the vast majority of MoF personnel still in situ lacked the basic qualifications to conduct even rudimentary fiscal functions. Tasks still being performed in the MoF were mostly of a clerical nature and carried out by the different MoF divisions in complete isolation from each other.

- $\quad$ The MoF's infrastructure had been devastated by years of war and neglect. This was especially true of a number of MoF regional offices and customs houses in the provinces, whose buildings were literally falling into ruins.

- $\quad$ Basic telecommunication facilities had failed, and most of the primary road network was impassable, resulting in the breakdown of fiscal relationships between the center and provinces. There was no office automation (in early 2002, there was only one calculator available for the whole Revenue Department), and key government offices lacked regular access to electricity. ${ }^{36}$

85. Budget policy was limited to the payment of salaries, and even these were subject to considerable delays and arrears. ${ }^{37}$ Budget preparation consisted of adding a large central reserve to the previous year's appropriations, which was drawn down during the year, depending upon the political pressures exerted by line-ministries. In violation of the budget law, line-ministries and provincial Mustufiats had opened a number of bank accounts in the regional branches of the central bank and state-owned banks, which were operated outside the purview of the MoF. ${ }^{38}$ No reconciliation was performed between the government's accounts in the central bank and the treasury in the MoF. The reporting system between the center and the provincial offices (Mustufiats) had broken down completely. The last annual government accounts prepared by the MoF accounting department related to 1989/90 and no

\footnotetext{
${ }^{36}$ This was in line with the country as a whole. The December 2001 World Bank, Asian Development Bank (AsDB), and United Nations Development Program (UNDP) preliminary needs assessment estimated that only 6 percent of Afghans had access to electricity in 1993 and Afghanistan had only 2 telephones per thousand people, compared with 24 in Pakistan, 35 in Tajikistan, and 68 in Uzbekistan.

${ }^{37}$ It is estimated that in December 2001, there was about $\$ 20$ million of salary arrears corresponding to wages incurred during the Taliban period.

${ }^{38}$ It has even been reported that the real Taliban treasury and central bank consisted of a couple of tin trunks in the house of Mohammad Omar (the leader of the Taliban regime) outside Kandahar. See Ewans (2002).
} 
government accounts had been put together since then. Most files and fiscal data were missing, including all records of the government's external debt.

86. The fiscal institutional framework featured a sharp contrast between the constitutional and legislative setup - providing for a highly centralized state with very limited deconcentration - and the reality on the ground was characterized by de facto fiscal autonomy of the provinces (see Box III.1). For most of the 1990s the central government had very limited control over the provinces, especially in the fiscal area. The revenues collected by provincial governors were neither reported nor remitted to the center and were spent offbudget, on expenditure items that were decided on the basis of local and factional interests. The Taliban regime apparently had some success in bringing the provinces under the rule of the center in the territories they controlled. But at the end of 2001, the provincial governors were, at the outset, very reluctant to comply with the country's centralized institutional framework.

\section{Box III.1. The Public Sector in Afghanistan and the Relationships Between the Center and the Provinces}

1. According to the 1964 Constitution and the 1966 Organic Budget Law, the public sector in Afghanistan is composed of ministries, provinces, districts, municipalities (provincial and rural), more than 170 nonfinancial public institutions, and several public financial institutions.

2. Under the law, provincial and district governments are deconcentrated offices of the central government rather than subnational levels of government. They comprise the provincial offices of the different central ministries and are administered by a governor, who is a civil servant directly appointed by the center. These provincial offices report both to the governor and to the corresponding lineministries. ${ }^{1 /}$ Provinces do not have a distinct budget nor do they collect their own revenues. At the request of the local office of each line-ministry, provincial expenditures are made by Mustufiat against the ministry's annual budget appropriations. Similarly, the revenues collected by the provinces are receipts of the national budget and can only be used by the provinces to finance the expenditures included in the line-ministries' budget; any surplus between centrally budgeted expenditures and locally collected revenues must be transferred to the center. The only exception to these rules concerns certain provincial and rural municipalities, which have very limited expenditure and revenue assignments (such as trash collection and park services) directly financed through the proceeds of local service charges.

1/ For instance, there is a Mustufiat in each province (provincial office of the MoF), placed under the authority of both the governor and the central MoF-and reporting to both.

87. Notwithstanding the dissolution of the system, a workable national fiscal process dating from before the conflict remained nominally in place, contrary to many other postconflict situations, where pre-existing fiscal arrangements were either very weak or nonexistent (for example, Kosovo and Timor-Leste). The existing fiscal laws and regulations, although imperfect and ignored for many years, provided a starting point for the 
reconstruction effort. There was no need to discard all past arrangements and invent completely new ones; the immediate challenge was rather to reactivate and reform a basically sound system, which had not been applied for many years.

88. The 1966 Organic Budget Law, for example, provided elements of good practice, such as the requirement that all revenues and grants should be collected and spent through the government treasury, and the obligation to reflect the full cost of government projects in the national budget. The entire public expenditure management system was comprehensively documented in the Organic Budget Law, Accounting Regulations and Treasury Manual, and a number of senior officers in the MoF were familiar with the procedures. Although often complex, obsolete, and cumbersome (and in need of review), these procedures provided the legal and administrative basis for the delivery of basic financial functions, including payment and recording of fiscal transactions, reporting, control, and (rudimentary) accounting. ${ }^{39}$ The Control and Audit Law also established a supreme audit authority responsible for the external audit of the whole government.

89. In spite of major weaknesses (see Chapter IV) and an urgent need for overhaul, a comprehensive tax system had also survived, based on the 1965 Income Tax Law and 1974 Customs Law, which includes individual and corporate income taxes, a form of sales tax (business receipt tax), fixed presumptive taxes and indirect taxes on trade (Annex IV.2).

90. Finally, the underlying arrangements for government employment stemmed from basically sound legislation providing for a system of centralized recruitment, job classification and grading. 40

\section{The Reconstruction Strategy: From Donor-Led Humanitarian Assistance TO GOVERNMENT-DRIVEN RECONSTRUCTION}

91. With the support of the international community, the AIA and its successor, the Afghan Transitional Administration (ATA), progressively outlined a government-led development agenda to address the humanitarian and reconstruction challenges facing the country. This process involved a number of different steps.

92. First, donor governments and international organizations helped the Afghan authorities to assess the external and technical assistance required to support Afghanistan's economic and social recovery over the short and medium term. In this context, in late 2001, the AsDB, the UNDP, and the World Bank conducted a preliminary assessment of the

\footnotetext{
${ }^{39}$ For instance, the different stages usually found in most public expenditure management systems (appropriations, apportionment of appropriation, commitments, payment orders, and payments process) are satisfactorily defined in the accounting regulations and the treasury manual.

${ }^{40}$ See World Bank (2002).
} 
funding requirements for the Afghanistan reconstruction program, covering 1, 21/2, 5, and 10 year horizons. ${ }^{41}$ These projections, presented at the International Conference on Reconstruction Assistance to Afghanistan in Tokyo on January 21-22, 2002, concluded that $\$ 14.6$ billion would be needed over a period of 10 years to fund Afghanistan's recovery, excluding humanitarian assistance. ${ }^{42}$ This assessment led to donor countries pledging $\$ 1.8$ billion in grants for the first year and $\$ 4.5$ billion mostly over the first $2 \frac{1}{2}$ years for Afghanistan's reconstruction (see Chapter II). Also, international agencies, including the IMF and the World Bank sent a number of diagnostic missions to the country to take stock of the existing situation (administrative structures, laws and regulations, suitability of staff, availability of facilities and equipment) and develop appropriate technical assistance action plans.

93. In the meantime, donors focused on providing immediate humanitarian relief to vulnerable Afghan people and ensuring regular payment of civil service salaries. In the first few months of the AIA, the international community was closely involved in these efforts (especially the UN system) as the machinery of government had not yet recovered enough to fully lead the recovery process. During this intermediate stage, the UN's Immediate and Transitional Assistance Programs (ITAPs) — covering the period October 2001 to December 2002 - were the main instruments through which UN institutions addressed the most urgent humanitarian needs of the Afghan population. These programs mainly focused on (a) the return and reintegration of refugees and internally displaced people; (b) food assistance; (c) rehabilitation of crop production; (d) child immunization; and (e) improvement of school enrollment, with estimated spending of $\$ 1.0$ billion $^{43}$ (Box III.2). Similarly, in the first six months of the AIA (January to June 2002), the payrolls of the civil service both at the center and in the provinces were processed, controlled, recorded, and financed through a specific fund, the Afghan Interim Administration Fund (AIAF), set up and administered by the UNDP. However, the preparation of the payroll and the actual payment of salaries were performed, from the onset, by the line-ministries and the MoF's treasury.

94. The Afghan authorities progressively took the lead in the formulation of the reconstruction strategy and put forward their vision for the country's future. The adoption of the 2002/03 operating budget, and the presentation of the National Development Framework (NDF) in April 2002 were turning points in this regard. They marked the government taking full leadership of the development agenda and an increased focus on reconstruction over humanitarian assistance. In particular, the first operating budget adopted on April 6, 2002 by the AIA was an important step in the establishment of the government's macroeconomic credibility, by prioritizing operating expenditures under the constraint of limited external

${ }^{41}$ The $2 \frac{1}{2}$-year horizon corresponds to the combined expected terms of the AIA and the ATA.

42 The financing required for the first year was estimated at $\$ 1.7$ billion and for the first $2 \frac{1}{2}$ years at $\$ 4.9$ billion.

${ }^{43}$ Excluding the civil service payments made by the Afghan Interim Administration Fund (AIAF). 


\section{Box III.2. The 2001-02 United Nation's Immediate and Transitional Assistance Programs}

On the basis of the AsDB, World Bank, and UNDP January 2002 preliminary needs assessment, the United Nations developed a set of emergency programs - Immediate and Transitional Assistance Programs for the Afghan People (ITAPs) - to deal with the ongoing humanitarian crisis facing Afghanistan. These programs, covering the October 2001-December 2002, were financed by $\$ 1.1$ billion from donor countries and achieved the main following results. ${ }^{1 /}$

1. Return and reintegration of refugees and internally displaced persons (United Nations High Commission for Refugees). Nearly 1.8 million refugees and 400,000 internally displaced persons were assisted to return home, in part under the government's voluntary repatriation program. Some 48,000 million tons (MTs) of food aid, 310,000 return packages, and \$35 million in travel grants were provided to returning families. 40,000 shelters were constructed in areas of return all over the country

2. Food Assistance (World Food Program). By December 2002, 250,000 MTs of food commodities had reached over 8 million people, and school feeding programs had reached 150,000 children; 1.8 million people had benefited from food aid provided through the "Food-for-AssetCreation" and over 250,000 received assistance through "Food-for-Work."

3. Rehabilitation of Crop Production and Food Security (Food and Agriculture Organization). During the 2002 spring season, 1,500 MTs of wheat seed and an equivalent amount of fertilizer were distributed to 40,000 farmers. During the 2002 autumn season, 3,800 MTs of wheat seed and 6,500 MTs of fertilizer were distributed to 80,000 farmers.

4. Health. Six million people were vaccinated against polio, preparing for total polio eradication by 2003 . Nine million children were vaccinated against measles.

5. Public Administration. Some $\$ 50$ million worth of civil servant salary payments were made with the support of the AIAF.

6. Education. The Ministry of Education, with UN and NGO support, launched a back-to-school campaign in March 2002, providing basic educational supplies (student kits, teacher kits, and blackboards) to 1.8 million children and 70,000 teachers at 4,500 schools.

$1 /$ This list is incomplete and includes only the most salient features.

assistance and setting up clear benchmarks for domestic revenue collection. In addition, the NDF, which was prepared through extensive consultations between the MoF, line-ministries, and the government, outlined the key principles underpinning the government's strategy. It was also a significant step taken by the government to move away from the mostly donordriven strategy underpinning the UN ITAPs to a truly government-led reconstruction process. The NDF focuses on three pillars of development: (a) human capital and social protection; (b) physical infrastructure; and (c) private sector development. Under these pillars the government developed 12 National Programs, among which 6 National Priority Subprograms 
have been identified to receive priority attention from donors and implementation agencies (Figure III.1). In the NDF, the government has committed to five main principles in the formulation and implementation of the development framework:

- Government leadership in the formulation of the development strategy. The authorities have progressively succeeded in making the budget the central instrument for policy-making. Although the government acknowledged from the outset that a number of reconstruction projects would be directly implemented by donors and NGOs, without the corresponding funds being channeled through the MoF, the authorities insisted that all development projects, including those independently implemented by donors, should be approved in the budget, as determined by the Cabinet. In parallel, the authorities obtained donors agreement that all available resources, whatever their sources, be reflected in the budget. This principle sought to avoid the emergence of parallel budgets, thereby ensuring a proper prioritization of expenditures and putting the government in the driver's seat in the reconstruction process.

- $\quad$ Reliance on market mechanisms and private-sector led growth rather then state intervention. The authorities have always made it clear that the state should not be involved in the production of goods and services, or manage directly the economy. They see the private sector as the main engine of growth and consider that the role of the state should be limited to providing security, investing in human capital, offering assistance to the most vulnerable and enabling a suitable environment for the development of the private sector.

- $\quad$ Programmatic approach to policy-making and resource allocation. Underlying the $\mathrm{NDF}$, there is a strong belief (confirmed by international experience) that investment projects would not be sustainable unless anchored in coherent programs. This strategy also aims at aligning donor support with the national priorities identified by the government and avoiding duplication of donor efforts.

- Government's transparency and accountability. Recognizing that accountable and transparent public expenditure management is critical for securing donor funding, the government reiterated publicly several times its commitment to fiscal transparency. It contracted three reputable international companies through competitive bidding to provide interim management and build government capacity in the key areas of fiscal reporting and accounting, procurement and audit (see Chapter IV).

- $\quad$ Priority on investing in security and human capital. Without security, development efforts have little chance of taking hold. In this regard, the authorities' priorities included the development of a national police force and army, reintegration of ex-combatants and revival of the judicial system. The authorities also put strong emphasis on immediate enhancement of the education system and school enrollment, especially of girls, considering that quality education is the foundation for economic development. One of the major achievements of the government in this area over the past year included getting three million children back to school. 
Figure III.1. Afghanistan: National Development Framework-Relationship Between the 3 Pillars, the 12 National Development Programs, and 6 National Priority Subprograms

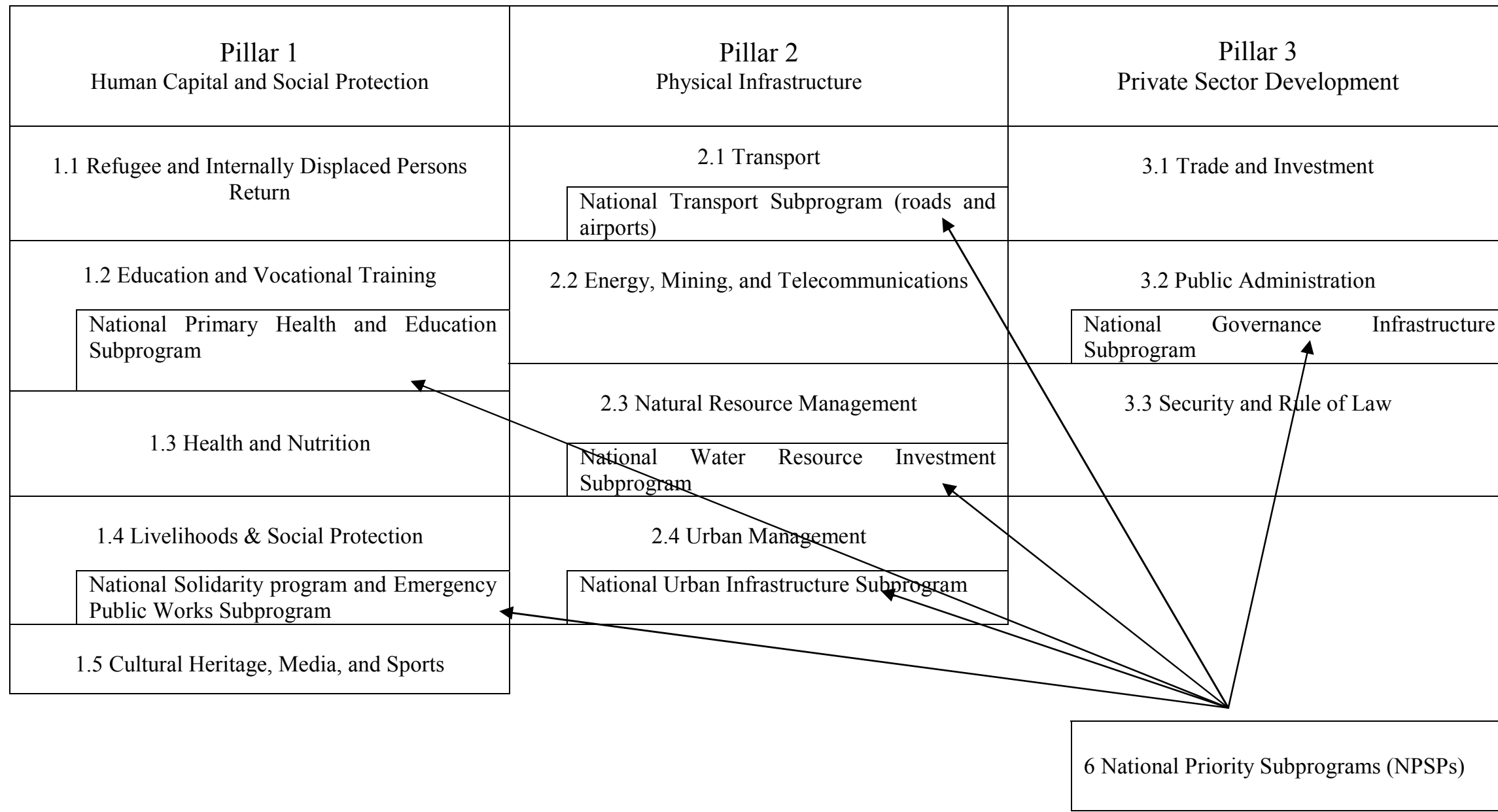

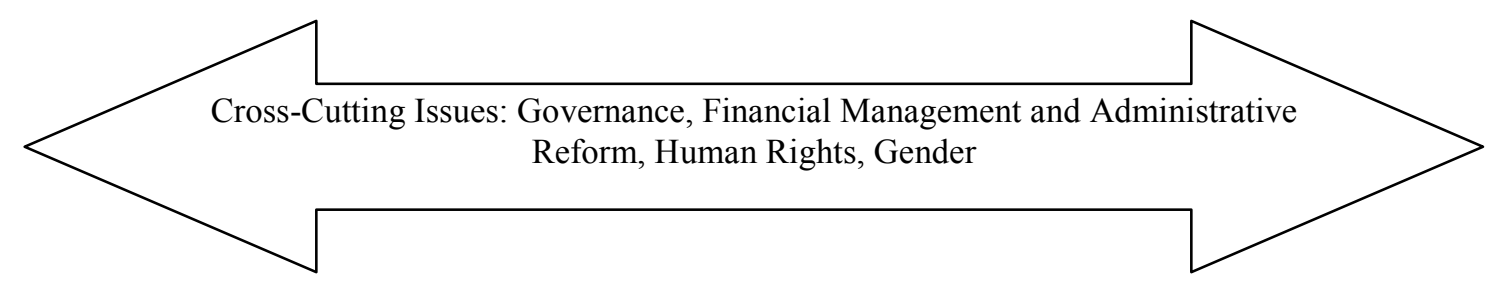


95. This process culminated with the adoption by the Cabinet, in March 2003, of the 2003/04 National Development Budget (NDB), translating the high-level architecture of the NDF into detailed development projects, with precise identification of funding sources for each project:

- $\quad$ The 2003/04 NDB marked full ownership by the government of the development agenda and made the budget the focal point for decision-making on government policy and the allocation of domestic and external resources. In particular, the NDB combined in a single document the 2003/04 operating and development budgets, the latter comprising most of the projects financed by the donor community, including the 2003/04 UN Transitional Assistance Programs (these projects, worth $\$ 815$ million, succeeded the 2002/03 ITAPs). This represented a significant improvement over 2002/03 when most of the development projects (including ITAPs) were carried out by donors outside the budget. This document was prepared by the $\mathrm{MoF}$ and approved by the Cabinet after extensive consultation and negotiation with line-ministries, including information compilation, strategy formulation, prioritization, and cut-offs to observe resource constraints.

- $\quad$ The adoption of the first NDB was accompanied by a significant reform of coordination between the government and donors, aimed at enhancing the effectiveness of government-donor interaction. Twelve Consultative Groups (CGs), covering the twelve major programs of the NDF were established and charged with the tasks of (a) preparing budget bids for MoF consideration during the preparation of the NDB; (b) monitoring the implementation of the operating budget; (c) reporting on the progress of the reconstruction strategy; and (d) offering a forum for general policy dialogue in the various sectors. Each CG is chaired by a lead line-ministry and includes all the UN agencies, donor countries, and NGOs, which are the most active in the program area. In addition to the CG structure, an Afghanistan High-Level Strategic Forum (AHSF) is convened every year in March with the participation of all the cooperation partners to discuss the budget for the next fiscal year, firm up external assistance pledges to the NDB, review priority areas and policy objectives, and assess progress made in the year before. The first AHSF took place in March 2003 and endorsed the first NDB.

\section{The Fiscal Policy Framework: Post-Conflict Budgeting}

96. During the first fiscal year of the new government $(2002 / 03)$, the authorities succeeded in maintaining fiscal discipline and providing basic services to the population despite the very difficult circumstances, including the continued lack of a satisfactory fiscal relationship between the center and the provinces, and a very low base for domestic revenues. Availability of external assistance during the year was a key factor in achieving this positive outcome. 
97. In 2003/04 (the current fiscal year), the authorities sought to increase the operating and development budgets, especially in the areas of security, education, health, and humanitarian assistance. Ensuring that this fiscal strategy remains compatible with the authorities' commitment to fiscal discipline will require that (a) the strong support pledged by the international community materializes; (b) domestic revenue collection increases to the ambitious level set out in the budget; and (c) significant progress can be made toward the fiscal unification of the country.

\section{The budget for 2002/03 (March 2002-March 2003): a positive outcome in spite of considerable difficulties}

98. The operating budget for 2002/03 (March 21, 2002-March, 20, 2003) was prepared with the assistance of the IMF and the World Bank staff, and adopted by the Cabinet on April $6,2002 .{ }^{44}$ The passage of this first budget was both a difficult challenge and a significant achievement given the total absence of reliable fiscal data from previous periods. This operating budget, covering all the state's fiscal transactions for both the center and the provinces, relied heavily on donor financing, and aimed primarily at ensuring the payment of civil service and military wages. ${ }^{45}$

99. Expenditures were budgeted at (new) Af 15.7 billion, plus an additional Af 750 million to clear wage arrears accumulated prior to the new government's tenure. This corresponded to a dollar amount of $\$ 483$ million (including clearance of wage arrears) using the exchange rate prevailing at that time of Af 34 per U.S. dollar as an accounting rate. This budget included a modest revenue target ( $\$ 83$ million or 17 percent of total spending), reflecting the narrow tax base (mostly customs duties) and the low domestic revenue collection observed in the first three months of the AIA. This left a gap of $\$ 400$ million (83 percent of the budget) to be financed by donor assistance (Table III.1), as the authorities precluded domestic financing of the budget. This budget also included a 240,000 cap on civil employees (of which 60 percent were in the provinces and 40 percent at the center), broken down by ministry. This allowed, in theory, the employment of all employees present on the payroll prior to the Taliban regime.

100. In terms of composition of expenditures (Table III.1), civil service wages (excluding the police and army but including the SOEs) were projected at \$120 million and military salaries were estimated at $\$ 99$ million, for a total estimated wage bill representing a little less

\footnotetext{
${ }^{44}$ Although preliminary development expenditure numbers were submitted to the international community in October 2002, there was no development budget as such in 2002/03 and development expenditures were directly carried out by donors. The authorities have made progress toward better integration of the operating and development budgets in the preparation of the 2003/04 NDB by presenting both budgets together.

45 In a break from past practice, under the new budget the wages of the provincial civil service were henceforth to be paid by the center.
} 
than 48 percent of total spending. ${ }^{46}$ Together with the police, security-related spending amounted to close to 45 percent of total spending, a proportion considered as justified given the need to reestablish security throughout the country. The low share of spending in health and education ( 20 percent of the total envelope) resulted from anticipated capacity constraints in the recruitment of new teachers in the first year, and the assumption that most development spending in the social sectors would be carried out by donors outside the operating budget.

Table III.1. Afghanistan: General Government Current Budget, 2002/03

(In millions of U.S. dollars)

\begin{tabular}{lr}
\hline & $2002 / 03$ \\
\hline 1. Wages and salaries (excl. defense, interior, national security, and SOEs) & 104.3 \\
Of which: allocation for wage reform & 24.1 \\
2. Goods and services (excl. defense, interior, and national security) & 60.7 \\
3. Capital expenditure (excl. defense, interior, and national security) & 14.4 \\
4. Defense, interior, and national security & 198.8 \\
$\quad$ Defense & 96.6 \\
$\quad$ Interior & 83.4 \\
$\quad$ National security & 18.9 \\
5. Subsidies to SOEs & 34.1 \\
$\quad$ Wages & 15.9 \\
$\quad$ Other & 18.3 \\
6. Social transfers & 18.8 \\
$\quad$ Of which: allocation for pension reform & 15.5 \\
7. Interest & 6.6 \\
8. Contingency & 22.5 \\
9. Total & 460.3 \\
10. Wage arrears clearance & 22.5 \\
11. Revenues & 83.0 \\
12. Financing need & 399.8 \\
13. Foreign grants & 399.8 \\
\hline
\end{tabular}

Sources: Afghanistan authorities; and IMF staff estimates.

101. Comparison between Afghanistan's 2002/03 operating budget with the operating budgets of a sample of low-income countries (Annex III.1) shows that, in 2002/03, budgeted current expenditure was, in percentage of GDP, much lower in Afghanistan than the sample average (11 percent compared with 18 percent). Similarly, the civil employment caps included in the 2002/03 budget places Afghanistan at the low end of public civil employment relative to population.

\footnotetext{
${ }^{46}$ Sum of the rows "wages and salaries" and "subsidies to SOEs wages" and half of the total appropriations for defense, interior, and national security in Table III.1. Excluding the clearance of wage arrears.
} 
102. The budget decree for the 2002/03 included a strong commitment to fiscal discipline by explicitly prohibiting the government from taking recourse to central bank financing (no-overdraft rule) and by limiting ministerial allotments to the amount of resources actually available in the government's accounts. ${ }^{47}$ Other elements of sound public expenditure management included the introduction of binding headcount ceilings for each ministry's civil service staff, provision that all state operating expenditures should be explicitly authorized in the budget, and the establishment of specific funding for wage and pension reforms. The decree also separated SOEs from the rest of the civil service, by removing the compensation due to SOE employees from the budgeted wage appropriations, making this instead part of the government's transfers and subsidies to SOEs. The authorities also publicly stated that they intended to restrict, to the extent possible, external borrowing to the financing of the development budget, that is, the operating budget would mainly rely on external grants.

103. According to preliminary estimates, actual spending in 2002/03 (including estimated nonwage provincial expenditures) reached 95 percent of budgeted amounts in Afghani terms (Table III.2). ${ }^{48}$ In U.S. dollar terms, expenditures amounted to an estimated \$349 million, much less than the $\$ 460$ million initially envisaged, due to the depreciation of the Afghani during the year (the annual average exchange rate was Af 44.5 per U.S. dollar whereas the budget accounting rate was Af 34 per U.S. dollar). ${ }^{49}$ In the first half of the year, budget spending was very low reflecting limited administrative capacity, a lack of financing, and a shortage of banknotes in the central bank before the currency conversion. Expenditures, however, picked up sharply in the second half of the year, especially in the fourth quarter, as donor disbursements accelerated and administrative capacity improved, and there was no longer a shortage of banknotes. Figures III.2 and III.3 show that budget execution (at the center during the last five months of the year) focused mostly on salary payments ( 74 percent of total spending, significantly more than the budgeted 48 percent), and on three priority sectors: security (43 percent), education (19 percent), and health ( 8 percent) ${ }^{50}$ Accordingly, the ministries that accounted for the highest shares of spending were defense, interior, education, health, and the president's office (the latter dispenses presidential discretionary funds that were reallocated to diverse expenditure items during the year).

\footnotetext{
${ }^{47}$ In the absence of a parliament, presidential decrees signed by the head of the AIA and ATA have the force of law.

${ }^{48}$ See paragraph 107 for an explanation of the estimation of nonwage provincial expenditures.

${ }^{49}$ Expenditures excluding the clearance of wage arrears.

${ }^{50}$ No comprehensive information on the composition of expenditures is available for the first seven months of the year, nor in the provinces. Sixteen percent of spending also related to "economic affairs" but this category lumps together highly different items.
} 
Table III.2. Afghanistan: Budget Execution, 2002/03

Center and Provinces

\begin{tabular}{|c|c|c|c|c|c|c|c|c|}
\hline & \multirow[t]{2}{*}{ Q1 } & \multirow[t]{2}{*}{ Q2 } & \multirow[t]{2}{*}{ Q3 } & \multirow[t]{2}{*}{ Q4 } & \multirow{2}{*}{$\begin{array}{l}\text { Comp. } \\
\text { period }\end{array}$} & \multicolumn{3}{|c|}{$2002 / 03$} \\
\hline & & & & & & $\overline{\text { Budget } 7}$ & Adjusted 8/ & Actual \\
\hline & \multicolumn{8}{|c|}{ (In million of U.S. dollars) } \\
\hline Domestic revenue & 18.0 & 26.9 & 41.0 & 46.1 & $\ldots$ & 83.0 & 63.5 & 131.9 \\
\hline Customs revenue 1 / & 9.9 & 14.3 & 21.2 & 22.3 & $\cdots$ & $\ldots$ & $\ldots$ & 67.8 \\
\hline Central ministries & 0.6 & 2.3 & 13.4 & 7.1 & $\ldots$ & $\ldots$ & $\ldots$ & 23.3 \\
\hline Noncustoms provincial $1 /$ & 7.5 & 10.3 & 6.3 & 16.7 & $\ldots$ & $\ldots$ & $\ldots$ & 40.8 \\
\hline Expenditure & 36.0 & 69.3 & 102.1 & 131.7 & 9.8 & 482.8 & 369.2 & 348.9 \\
\hline Center & 18.0 & 34.1 & 67.5 & 67.7 & 5.7 & $\ldots$ & $\ldots$ & 193.1 \\
\hline Provinces (payroll only) 2/ & 3.0 & 11.0 & 14.8 & 33.6 & 4.1 & $\ldots$ & $\ldots$ & 66.5 \\
\hline Net presumptive provincial expenditures 3 / & 15.0 & 24.2 & 19.8 & 30.3 & $\ldots$ & $\ldots$ & $\ldots$ & 89.3 \\
\hline Balance (MoF) & -18.0 & -42.4 & -61.1 & -85.6 & -9.8 & -399.8 & -305.7 & -217.0 \\
\hline Float and adjustment 4 / & 0.4 & -0.7 & -0.9 & -6.4 & -7.1 & $\ldots$ & $\ldots$ & -14.8 \\
\hline Balance (DAB) & -17.7 & -43.1 & -62.1 & -92.0 & -16.9 & -399.8 & -305.7 & -231.8 \\
\hline Donor assistance grants & 26.3 & 38.5 & 37.9 & 60.8 & 19.9 & $\ldots$ & $\ldots$ & 183.5 \\
\hline Bilaterals & 10.0 & 10.0 & 6.4 & 0.0 & 0.0 & $\ldots$ & $\ldots$ & 26.4 \\
\hline UNDP & 16.3 & 10.0 & 0.0 & 0.0 & 0.0 & $\ldots$ & $\ldots$ & 26.3 \\
\hline ARTF & 0.0 & 18.5 & 30.3 & 56.3 & 19.7 & $\ldots$ & $\ldots$ & 124.9 \\
\hline LOTFA & 0.0 & 0.0 & 1.2 & 4.5 & 0.0 & $\ldots$ & $\ldots$ & 5.7 \\
\hline Others & 0.0 & 0.0 & 0.0 & 0.0 & 0.2 & $\cdots$ & $\cdots$ & 0.2 \\
\hline Donor assistance loans & 0.0 & 0.0 & 0.0 & 25.0 & 0.0 & $\cdots$ & $\cdots$ & 25.0 \\
\hline Other financing 5 / & 0.0 & 22.8 & 4.2 & 12.0 & 0.0 & $\ldots$ & $\cdots$ & 39.0 \\
\hline Exchange rate adjustment 6 / & -6.4 & -7.4 & 4.0 & 8.4 & 1.5 & $\ldots$ & $\ldots$ & 0.1 \\
\hline Surplus/deficit net & 2.2 & 10.8 & -16.0 & 14.2 & 4.5 & $\ldots$ & $\ldots$ & 15.8 \\
\hline
\end{tabular}

Sources: Ministry of Finance; DAB; and IMF staff estimates.

Memorandum item:

- All arrears to the World Bank, AsDB, and IMF were cleared in 2002/03 through the use of grants (\$51.2 million) and Afghanistan's reserve tranche with the IMF (\$5.7 million).

1/ As reported to the MoF. However, only a small part of this money is remitted to the center (transfers received by the MoF).

2/ Provincial salaries were paid by the center except for Herat province which paid the salaries of its government staff out of the revenues it collected.

3/ Because no reliable data on nonwage provincial expenditures are available at the center at this date, these expenditures are assumed to equal the provincial revenues reported to the center plus net transfers from the center.

4/ Variation between the fiscal position recorded at MoF and DAB. This discrepancy is due to the difference ("float") between checks issued and cashed and the fact that the provinces' accounts in DAB branches were not consolidated into the government's central accounts at the end of the year.

5/ International Air Transport Association (IATA) accumulated overflight fees, sale of a telecommunications license, one-off transfer from the Ministry of Commerce, and transfer of previous year's provincial surpluses.

6/ This adjustment reflects the difference between the exchange rate used for donor grants (actual exchange rate at the time of deposit in the government's accounts) and the average exchange rate used to convert into U.S. dollar the other components of the table (Af $44.46=\$ 1$ ).

7/ Including Af 750 million for the clearance of wage arrears related to payrolls incurred before the interim administration took power in January 2002.

8/ The approved budget was expressed in Afghanis and was converted into U.S. dollar at the time of its adoption (March 2002) using an accounting exchange rate of Af $34=\$ 1$. The depreciation of this rate to an annual average exchange rate of Af $44.46=\$ 1$ results arithmetically in a downward adjustment of the U.S. dollar amount of the budget. 
Figure III.2. Afghanistan: Budget Execution-Economic Classification, 2002/03 (Last five months of the fiscal year)

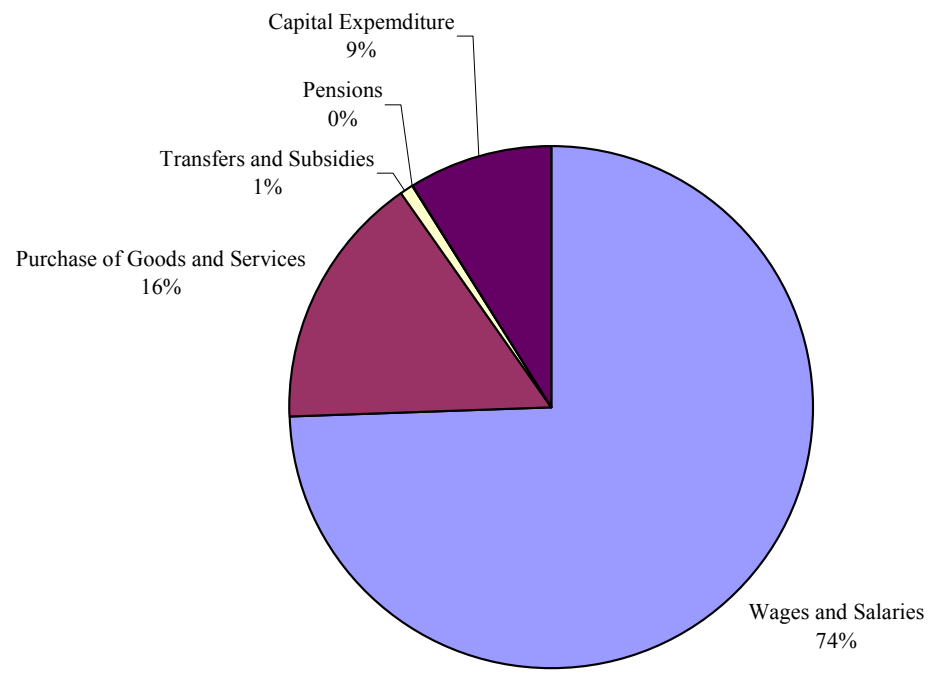

Sources: MoF; Afghanistan Financial Management Information System.

Figure III.3. Afghanistan: Budget Execution-Functional Classification, 2002/03 (Last five months of the year)

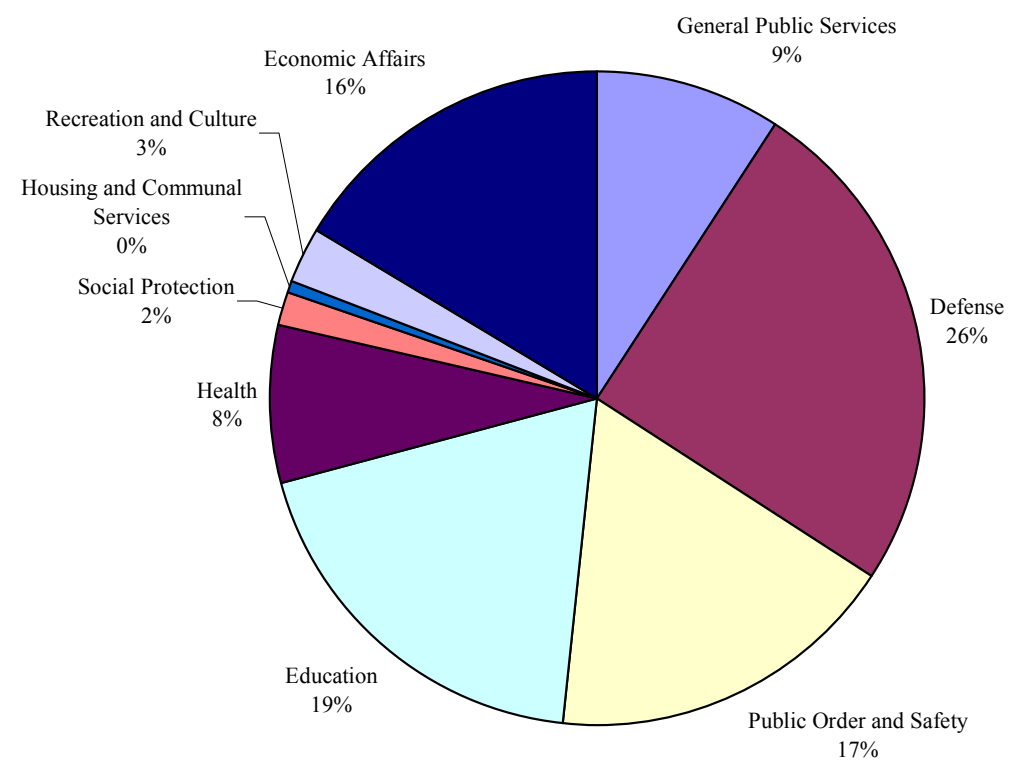

Sources: MoF; Afghanistan Financial Management Information System. 
104. Domestic revenue as reported to the center is estimated to have reached about \$132 million, significantly higher than the budgeted \$83 million. More than 80 percent of the reported revenues were collected in the provinces, with the remainder coming from the lineministries at the center. About 60 percent of the locally collected revenues were customs revenues (a breakdown of noncustoms revenues into the different categories of revenues is not available). But only a small proportion of the reported provincial revenues were actually transferred to the central government's accounts.

105. These factors combined have limited the financing requirement to an estimated \$232 million (66 percent of total spending), considerably less than the initially planned $\$ 400$ million. This gap was mainly met through (a) donor assistance grants (\$183 million), including support (\$125 million) from the Afghanistan Reconstruction Trust Fund (ARTF; see Box III.3), and through (b) one-off receipts ${ }^{51}$ (\$39 million); and (c) partial use of an external loan extended by the Asian Development Bank ( $\$ 25$ million), leaving a positive balance of $\$ 16$ million at the end of the year ${ }^{52}$ (Table III.2).

\section{Box III.3. The Afghanistan Reconstruction Trust Fund}

The main source of funding for the 2002/03 operating budget was the Afghanistan Reconstruction Trust Fund (ARTF), which covered 54 percent of the funding requirement. Established in April 2002, the ARTF is a coordinated funding mechanism administered by the World Bank, which provides financial grant support to the Afghan government in three main areas of expenditures: recurrent civil costs of the government (excluding the army and national security), priority investments, and benefits granted to returning expatriate Afghan professionals. In 2002/03, ARTF disbursements almost entirely focused on the first component; under the second component, only four investment projects were approved (on a commitment basis) in late 2002 and no disbursement has yet taken place under the third component (return of Afghan expatriates). The ARTF is governed by a Management Committee, consisting of representatives of the Asian Development Bank, Islamic Development Bank, UNDP, and World Bank, with day-to-day administration of the Fund performed by the World Bank. A Monitoring Agent has been appointed by the World Bank to ensure proper fiduciary management; a Donor Committee supervises the management and administration of ARTF and provides policy-guidance.

106. The execution of the first operating budget of the AIA/ATA included a number of positive features. First, the authorities respected their commitment to fiscal discipline. The prohibition of monetary financing of the budget (no-overdraft rule) was observed, except in the third quarter, when the government's account went temporarily into overdraft due to time lags in donor disbursements and a lack of communication between the MoF and the central

\footnotetext{
${ }^{51}$ Including: \$22 million from the International Air Transport Association in accumulated overflight rights; $\$ 5$ million from the sale of a telecommunications license; $\$ 7$ million of customs valuation fees accumulated in the past few years, $\$ 4$ million of last year's provincial surpluses.

52 This figure includes the external assistance deposited by donors in the central bank's account in U.A.E. but not yet transferred to the government's accounts.
} 
bank. Second, despite a slow start, most of the annual budget was spent and the budget was truly national in scope since more than 45 percent of the estimated spending benefited the provinces. ${ }^{53}$ Third, actual spending reflected the government's sectoral priorities for education, health and social protection, and security. Fourth, domestic revenue collection as reported to the MoF was much higher than envisaged in the budget. And fifth, expenditures were fully financed from revenues, grants, and loans, and the government ended with a significant positive balance at the end of the year.

107. These achievements were all the more significant given that the execution of the 2002/03 operating budget — and its monitoring — was undertaken in the context of a number of obstacles, which will need to be addressed in 2003/04. The main obstacle was the lack of unity of the fiscal system due to weak central control over the provinces. Although provinces collected the bulk of domestic revenues and reported these revenues to the center-albeit with considerable time lags — only very limited amounts of these revenues were actually transferred to the central government's accounts during 2002/03 (about 27 percent). ${ }^{54}$ The reluctance of most provinces to transfer local revenues also led to the collapse of the equalization system between "rich" provinces (border provinces collecting large customs revenues) and "poor" provinces (inland provinces). In the absence of revenue remittances from the rich provinces, the government found itself unable to allocate to the provinces the transfers budgeted in the budget decree. In addition, contrary to the existing fiscal regulations, most provinces did not send to the MoF reliable reports on their nonwage expenditures, for which comprehensive information was therefore unavailable for 2002/03. This missing information seriously complicated the monitoring of the execution of the budget at both the center and the provinces. To compare actual spending with the budget the authorities had to estimate the provinces' unknown nonwage expenditures by assuming that all revenues collected by each province were entirely spent by the same province. ${ }^{55}$ Furthermore, it was only during the second half of the year that it became possible to get a clear and reliable picture of spending by ministry and by economic or functional categories, and this was only for the center, following the introduction of a computerized system of expenditure recording at the $\mathrm{MoF}$.

108. There were also problems in estimating the number of permanent staff employed by the government in 2002/03 and enforcing the recruitment ceilings included in the budget decree. This was for the following reasons: (a) the preparation of a nominal roll of employees for the whole country was a long and resource-demanding process, which the authorities

\footnotetext{
${ }^{53}$ Including “presumptive nonwage provincial expenditure." See paragraph 107.

${ }^{54}$ It is also likely that revenues reported by the provinces were well below the revenues actually collected by the provinces. The 1964 Organic Budget Law requires that any positive balance between locally collected revenues and budgeted expenditure should be promptly sent to Kabul.

55 Nonwage provincial expenditures are thus estimated as equal to provincial revenues reported to the center plus net transfers received from the center.
} 
were not able to complete during 2002/03; (b) the executed provincial payroll could not be broken down by ministry in the first half of the year; (c) contrary to the provisions of the budget decree, a part of the staff working in the SOEs continued to be directly paid through the government payroll and not through transfers to the SOEs; and (d) a number of provinces apparently hired and paid a significant number of civil service staff directly out of their local revenues without informing the center.

109. Although the overall initial budget ceiling was respected, important reallocations between expenditure items were made during the fiscal year without the budget being revised accordingly: (a) government employees' food allowances were raised by 37 percent in May 2002 to increase government wages from their very low levels; (b) food in-kind distributed to civil service staff by the World Food Program was replaced in September 2002 by a new monetary allowance; (c) civil servants received in November 2002 a salary bonus corresponding to one-month salary ("Ramadan bonus") to ease the social tension stemming from the depreciation of the Afghani during the currency conversion (see Chapter V); and (d) a number of line-ministries, including the Ministry of Education, apparently hired more staff than authorized in the budget decree. These slippages in the execution of the budget were financed within the overall budget ceiling through the use of the substantial 2002/03 presidential reserve fund and the wage and pension reform reserves (no such reforms took place in 2002/03).

110. No detailed information is available on expenditures directly spent by donors on development projects in 2002/03 as the Afghanistan Aid Coordination Agency (AACA) has not yet received comprehensive information on donors' project financing. It is estimated however that total disbursements of external assistance reached about $\$ 1.4$ billion (excluding support for the operating budget). Less than 40 percent of these funds, which were channeled outside the government's budget, went to reconstruction, the remaining being allocated to humanitarian relief. ${ }^{56}$

\section{The budget for 2003/04 (March 2003-March 2004): increasing domestic revenues and securing high levels of external assistance to begin the reconstruction process}

111. The authorities presented both the 2003/04 operating and development budgets - for a total of $\$ 2.3$ billion - to the donor community during the first AHSF held in Brussels in March 2003.

112. The budget decree for 2003/04, which outlines Afghanistan's fiscal policy for the current fiscal year, reiterated the authorities strong commitment to fiscal discipline. The decree explicitly reaffirms the government's commitment to the principle of no government overdraft with the central bank. It also includes, as in the previous year, ceilings for total staff by ministry, but unlike last year the authorities supposedly have the technical capacity to

${ }^{56}$ ATA and AACA (2003). 
meaningfully monitor, and effectively enforce, these ceilings. ${ }^{57}$ The budget decree furthermore restricts external borrowing to $\$ 300$ million for the entire fiscal year and limits its use to the funding of development projects and meeting temporary cash flow requirements for the operating budget. The decree specifically mentions the passage of a customs reform package and ranks the centralization of revenues as one of the government's priority tasks for the year. A Civil Service Reform Fund (\$20 million) has been established to accommodate the much needed reforms of the civil service (see Chapter IV). The reserve funds of the operating budget have meanwhile been reduced and are subject to tighter controls. ${ }^{58}$

113. The 2003/04 operating budget envisages expenditures equivalent to $\$ 550$ million, an increase of 58 percent compared to last year's outcome, reflecting the fact that in 2002/03 government spending was constrained by limited absorptive capacity. Almost 40 percent of planned spending is allocated to defense, public order, and safety, 24 percent to education, and about 10 percent to health and social protection. (Table III.3). Wage and salary payments account for 50 percent of the budget, which represents a significant reduction in the weight of wages in the operating budget, compared to actual spending in 2002/03 (74 percent).

114. Domestic revenues are budgeted to reach $\$ 200$ million. This ambitious revenue target (52 percent more than domestic revenues collected in 2002/03) is based upon the assumptions of: (a) strong economic growth (see Chapter II); (b) an increase in revenue collection expected from the planned customs reform (see Chapter IV); and (c) the effective centralization of locally-collected revenues.

115. This revenue assumption leaves a $\$ 350$ million financing gap to be covered by foreign assistance, of which $\$ 250$ million is projected to be financed through the ARTF. Military and other security expenditures, which are not eligible for financing through the ARTF, are expected to be financed through domestic revenues and by $\$ 100$ million in donor assistance channeled through the Law and Order Trust Fund for Afghanistan (LOTFA) and the Army Trust Fund (these two trust funds, managed by the UN, were established in 2002 to channel donor assistance to support military and security recurrent expenditures). The authorized headcount ceiling for civilian employees was set at 356,000, which represents a 50 percent increase over last year's budget (whose civil employment cap was low by international standards, see Annex III.1), mainly concentrated in the Ministry of Education, growing from an authorized level of 72,000 last year to 166,000 this year. According to the authorities however, 60,000 new staff only (mainly teachers) will be hired this year; the remainder of the increase will result from the recording of staff who were already paid by the provinces in 2002/03 from local revenues, but whose payroll was not reported to the center.

\footnotetext{
57 This is due to the fact that the budget decree includes an obligation for each Ministry to break down their headcount ceilings into "sub-ceilings" for the center and each province, which was not the case in 2002/03. 58 "Unallocated items" in the economic and functional classification of expenditures in Table III.3.
} 
Table III.3. Afghanistan: Operating Budget, 2003/04

\begin{tabular}{lcc}
\hline & \multicolumn{2}{c}{$2003 / 04$} \\
\cline { 2 - 3 } & $\begin{array}{c}\text { In million of } \\
\text { U.S. dollars 1/ }\end{array}$ & $\begin{array}{c}\text { Percent of } \\
\text { total spending }\end{array}$ \\
\hline Domestic revenues & 200.0 & 36 \\
Expenditures & 550.0 & 100 \\
Economic classification & 550.0 & 100 \\
Wages and salaries & 276.6 & 50 \\
Goods and services & 178.4 & 32 \\
Capital expenditure & 39.2 & 7 \\
Transfers & 24.5 & 4 \\
Interest & 6.7 & 1 \\
Unallocated & 24.6 & 4 \\
Functional classification & 550 & 100 \\
General public services & 48.7 & 9 \\
Defense & 128.0 & 23 \\
Public order and safety & 81.7 & 15 \\
Education & 132.5 & 24 \\
Health & 27.9 & 5 \\
Social protection & 24.6 & 4 \\
Housing and communal services & 1.3 & 0 \\
Recreation and culture & 13.3 & 2 \\
Economic affairs & 40.5 & 7 \\
Unallocated & 51.5 & 9 \\
Financing requirement & 350.0 & 64 \\
ARTF & 250.0 & 45 \\
LOTFA and Army Trust Fund & 100.0 & 18 \\
Memorandum items: & & \\
Number of civil servants & 456,000 & $\ldots$ \\
Of which: military & 100,000 & $\ldots$ \\
Average monthly wage (in U.S. dollars) & 50.6 & $\ldots$ \\
\hline Sourcs: Afghastan athoties; and & &
\end{tabular}

Sources: Afghanistan authorities; and IMF staff estimates.

1/ Unless otherwise indicated.

116. The 2003/04 development budget, which is the first real development budget prepared by the ATA, amounts to $\$ 1.8$ billion (Table III.4), ${ }^{59}$ to be fully financed by external assistance. Over one-third of the development budget is expected to be spent on the rehabilitation of infrastructure, another one-third on health, social protection, and humanitarian assistance and 14 percent on education. All donor projects are supposed to be reflected in the budget, especially most of the Transitional Assistance Programs for Afghanistan (TAPA; successors to ITAPs) carried out by UN agencies ( $\$ 750$ million of the $\$ 815$ million envisaged for TAPAs 2003/04 is included in the development budget).

\footnotetext{
${ }^{59}$ Actual disbursements during the year, however, are expected to be less, depending on the disbursement pace of the various multiyear projects.
} 
However, full comprehensiveness has not been achieved yet since the budget envelopes do not include the development costs for the Afghan National Army, the Counter-Narcotics Program and the preparation of the national elections to be held in mid-2004. ${ }^{60}$

Table III.4. Afghanistan: Development Budget, 2003/04

\begin{tabular}{lrr}
\hline & \multicolumn{2}{c}{$2003 / 04$} \\
\cline { 2 - 3 } & $\begin{array}{c}\text { In millions } \\
\text { of Afghanis }\end{array}$ & \\
\hline Pillar I: Human and Social Protection & 858.3 & 48.2 \\
Refugee return & 162.6 & 9.1 \\
Education & 244.0 & 13.7 \\
Health and nutrition & 173.5 & 9.7 \\
Rural livelihoods and social protection & 248.0 & 13.9 \\
Culture/media/sports & 30.2 & 1.7 \\
Pillar II: Physical Infrastructure & 637.2 & 35.8 \\
Transport and telecommunications & 253.6 & 14.2 \\
Energy, mining & 162.4 & 9.1 \\
Natural resources & 146.1 & 8.2 \\
Urban management & 75.2 & 4.2 \\
Pillar III: Private Sector Development & 284.8 & 16.0 \\
Trade and investment & 5.5 & 0.3 \\
Public administration & 87.9 & 4.9 \\
Justice & 27.0 & 1.5 \\
Interior & 98.4 & 5.5 \\
Mine action & 66.1 & 3.7 \\
Total & $1,780.4$ & 100.0 \\
\hline
\end{tabular}

Source: Afghan authorities.

Memorandum item (items not included in the development budget):

- Mine Action Program

- Afghan National Army Development Costs

- Counter Narcotics Program

- MIGA Investement Guarantee Trust Fund

\footnotetext{
${ }^{60}$ The Afghan National Army and Counter-narcotics Program development expenditures have been kept outside the budget for confidentiality reasons and because they will be planned and executed directly by specific bilateral donors. The cost of the national elections is not included in the 2003/04 budget because it was not known at the time the budget was prepared.
} 
117. Preliminary budget execution data, covering the first five months of the fiscal year, provide positive indications that the authorities have adhered to their commitment to fiscal discipline and have effectively enhanced domestic revenue mobilization (Table III.5). Revenue performance reached $\$ 31$ million in the first quarter of 2002/03-a 72 percent increase over the same period last year ( $\$ 18$ million) — and most of these reported revenues (still mainly collected in the provinces) were transferred to the government's central accounts. In addition, the provinces transferred $\$ 12$ million of their 2002/03 surplus revenues to the center. If this trend is sustained, the total domestic resources available to finance the operating budget could well reach \$150-200 million (but attainment of the upper limit of this range will depend upon whether the customs reform package is implemented as planned). On the other hand, spending has been off to a slow start (only 24 percent of the annual budget was spent in the first five months), mainly due to large delays in payments of provincial and military salaries. ${ }^{61}$ The no-overdraft rule has been observed so far and the government's accounts show comfortable surpluses at the end of the fifth month ( $\$ 63$ million), reflecting (a) slow spending; (b) the positive balance remaining at the end of 2002/03; (c) transfers from a number of provinces of accumulated 2002/03 revenues; (d) sizeable disbursements of external assistance; and (e) a transfer to the government's accounts of $\$ 33$ million from the proceeds of a loan disbursed by the AsDB in late 2002, which initially was planned to be used for the development budget. No comprehensive information on the execution of the development budget is currently available, although partial reports indicate that project expenditures have been much lower than budgeted. The government is currently undertaking an in-depth review of the execution of the development budget in order to identify bottlenecks and capacity constraints in project implementation and to reflect new pledges that donors have made since the March 2003 AHSF. $^{62}$

118. The authorities have recently made important progress to address the serious weaknesses which hampered the execution of the 2002/03 budget. The most significant step in this regard was an agreement concluded between the central government and provincial governors to enforce effective centralization of provincial revenues. In May 2003, the National Security Council chaired by President Karzai issued an instruction co-signed by the major provincial governors, ordering that (a) all provincial tax and customs revenues be recorded and transmitted to the center on a regular and timely basis; (b) provincial authorities refrain from meeting their expenditures directly out of their local revenues; and (c) provincial expenditures be limited to budget allotments received from the center. A major challenge will be to ensure that provincial governors comply with their signed agreement. If they do, this will prove an essential milestone toward the fiscal unification of the country. The sharp increase of provincial transfers in the first five months of the fiscal year over the same period

\footnotetext{
${ }^{61}$ Including an exceptional payment of $\$ 25$ million in Herat province in the first month related to the advance payments of public works contractors.

${ }^{62}$ The U.S. administration has publicly announced its intention to allocate an additional $\$ 1$ billion aid package to Afghanistan. However, the decision remains to be confirmed and the modalities of its integration with the NDB are not yet determined.
} 
Table III.5. Afghanistan. Operating Budget, 2003/04

Execution of the first five months of the year

\begin{tabular}{|c|c|c|c|c|}
\hline & $\begin{array}{l}\text { Annual } \\
\text { budget }\end{array}$ & Q1 & $\begin{array}{c}\text { Months } \\
4-5\end{array}$ & $\begin{array}{c}\text { Year to } \\
\text { date }\end{array}$ \\
\hline & \multicolumn{4}{|c|}{ (In million of U.S. dollars) } \\
\hline Domestic revenue $1 /$ & 200.0 & 31.4 & & $\ldots$ \\
\hline Center & $\ldots$ & 3.3 & 2.8 & 6.1 \\
\hline Provinces & $\ldots$ & 28.1 & $\ldots$ & $\ldots$ \\
\hline Expenditure 2/ & 550.0 & 76.2 & 55.8 & 132.0 \\
\hline Center-provinces & $\ldots$ & 76.2 & 55.8 & 132.0 \\
\hline Central government 3 / & $\ldots$ & 35.5 & 41.6 & 77.1 \\
\hline Provinces 4/ & $\ldots$ & 40.7 & 14.2 & 54.9 \\
\hline Economic classification & 550.0 & 76.2 & 55.8 & 132.0 \\
\hline Wages and salaries & $\ldots$ & 32.4 & 37.1 & 69.5 \\
\hline Purrchase of goods and services 4/ & $\ldots$ & 36.0 & 10.5 & 46.5 \\
\hline Transfers and subsidies & $\ldots$ & 2.8 & 2.7 & 5.5 \\
\hline Pensions & $\ldots$ & 0.0 & 2.7 & 2.7 \\
\hline Capital expenditure & $\ldots$ & 4.9 & 2.9 & 7.8 \\
\hline Functional classification & 550.0 & 76.2 & 55.8 & 132.0 \\
\hline General public services & $\ldots$ & 6.8 & 7.8 & 14.6 \\
\hline Defense & $\ldots$ & 18.6 & 8.7 & 27.2 \\
\hline Public order and safety & $\ldots$ & 9.3 & 15.8 & 25.1 \\
\hline Education & $\ldots$ & 5.4 & 10.1 & 15.5 \\
\hline Health & $\ldots$ & 2.9 & 3.6 & 6.5 \\
\hline Social protection & $\ldots$ & 0.4 & 2.5 & 2.9 \\
\hline Housing and communal services $4 /$ & $\ldots$ & 26.4 & 0.1 & 26.5 \\
\hline Recreation and culture & $\ldots$ & 0.8 & 1.2 & 2.1 \\
\hline Economic afffairs & $\ldots$ & 5.7 & 5.9 & 11.6 \\
\hline Balance (MoF) & -350.0 & -44.8 & $\ldots$ & $\ldots$ \\
\hline Float and adjustment 5/ & $\ldots$ & 26.4 & $\ldots$ & $\ldots$ \\
\hline Balance (DAB) & -350.0 & -18.4 & -43.6 & -62.0 \\
\hline Donor assistance grants & 350.0 & 46.6 & 19.6 & 66.2 \\
\hline ARTF & 250.0 & 46.6 & 10.8 & 57.4 \\
\hline LOTFA and Army Trust Fund & 100.0 & 0.0 & 8.8 & 8.8 \\
\hline Loans & $\ldots$ & 33.2 & 0.0 & 33.2 \\
\hline Balance end-2002/03 & $\ldots$ & 12.4 & 0.0 & 12.4 \\
\hline Transfer of 2002/03 provincial surpluses & $\ldots$ & 12.5 & 1.0 & 13.6 \\
\hline Exchange rate adjustment $6 /$ & $\ldots$ & -0.1 & 0.0 & -0.1 \\
\hline Surplus net (including \$ not yet converted into Afs) & $\ldots$ & 86.3 & -22.9 & 63.4 \\
\hline
\end{tabular}

Sources: Ministry of Finance; DAB; and IMF staff estimates.

$1 /$ As reported to the MoF. However a small part of this money is remitted to the center (transfers received by the MoF). 2/ Checks issued by MoF.

3/ Provincial salaries are paid by the center except for Herat province which pays the salaries of its government staff out of the revenues it collects.

4/ Including \$25.2 million paid in the first month by the Ministry of Reconstruction in Herat province for the purchase of services (advance payments to contractors).

5/ Variation between the fiscal position recorded at MoF and DAB. This discrepancy is due to the difference ("float") between checks issued and cashed, and the fact that the provinces' accounts in DAB branches are not yet consolidated into the government's central accounts. The magnitude of this adjustment reflects the fact that $\$ 25$ million paid by Herat province in the first month was not included in the government's central accounts at DAB.

6/ This adjustment reflects the difference between the exchange rate used for donor grants (actual exchange rate at the time of deposit in the government's accounts) and the average exchange rate used to convert into U.S. dollar the other components of the table $($ Af $48.61=\$ 1)$. 
last year is a positive indication in this regard. In parallel with this initiative, 40 newlytrained fiscal experts will be sent to the provinces (including 6 foreign consultants stationed in the largest provinces) to enhance financial reporting from the provinces on their revenues and expenditures, and to follow up locally on the agreement on revenue centralization (see Chapter IV).

119. Notwithstanding the agreement concluded with the provinces, maintaining fiscal discipline in 2002/03, and delivering on the ambitious policy objectives included in the budget will not be an easy task. The sharp increase in the budgeted amounts over the previous years can only be compatible with the continued observance of fiscal discipline, if (a) fiscal relationships with the provinces improve; (b) effective revenue centralization is achieved; (c) increased domestic revenues are mobilized, especially through promoting private sector development; and (d) most important of all, the large external assistance projected in the budget materializes. The latest projections show that, for the operating budget, pledges of external assistance are still short of about $\$ 100$ million compared with budget requirements. This shortfall relates mainly to army and police expenditures. For the development budget, the AACA estimate that commitments are about $\$ 700$ million short of the budgeted amount. This last point highlights the need for donors to mobilize the necessary resources. To ensure an adequate pace of implementation, it will also be important for donors to disburse their pledges in a timely and predictable fashion. 


\section{Annex III.1 The Twelve National Programs of Afghanistan's National Development Framework ${ }^{63}$}

The following provides a summary of the 12 national programs of the government's National Program for Reconstruction. Information has been taken from government documents including the National Development Framework and the National Development Budget.

Refugee Return: With an unprecedented number of refugees returning to Afghanistan and settling in urban centers, facilities and services - already severely pressed to serve current residents - are being stretched beyond capacity. This program aims to improve information, registration and documentation of refugees, and provide support to the neediest and their host communities. Specific measures are being taken to cater to the needs of the most vulnerable during the cold winter months. The program will also address policy and institutional issues and develop the capacity of government agencies charged with assisting refugees and coordinating their reintegration.

Education: Given the appalling conditions of the education system in the country, evidenced by the population's education indicators - among the worst in the world - and the destruction of much of the country's educational institutions, development of the education system is a vital need for future growth and development in Afghanistan. The education program covers a range of essential areas, including improving education infrastructure, teacher development, increased primary and secondary school enrolment with a particular focus on female enrollment, as well as vocational training and early childhood development.

Health and Nutrition: Infant, child, and maternal mortality rates in Afghanistan are very high and there is widespread prevalence of communicable diseases and poor nutrition. The health and nutrition program will therefore focus on decreasing mortality rates through the provision of basic packages of health services, and increasing the capacity of government to develop necessary systems and policies, as well as implementing a number of specific interventions, including safe motherhood and nutrition programs. The expected results are quantifiable improvements in health indicators as well as improvements in health infrastructure and institutional capacity within relevant agencies.

Livelihoods and Social Protection: Aimed to address the risk and deprivation experienced by large parts of the rural Afghan population, this program will focus on five areas: institutional strengthening, macroeconomic regeneration, community-based development, protection of lives and livelihoods, and income generation. It is hoped that communities will be empowered through being directly involved in designing and implementing reconstruction efforts in their communities. This program will also address issues of the disabled who comprise nearly 4 percent of the population.

${ }^{63}$ See World Bank (2003). 
Cultural Heritage, Media, and Sports: Recognized as a key element in consolidating a common Afghan identity, particularly during the transitional period, this program will promote a number of activities, including the preservation of Afghan cultural heritage, rehabilitation of sports infrastructure, rehabilitation of the media with participation of women encouraged in all areas.

Transport and Telecommunications: The vital role of good communication and transport networks in economic development and national integration form the basis of this program. Suffering significant destruction and neglect through years of war, large investments are planned in these networks. In addition to building physical infrastructure for both national and secondary roads, this program will also create a regulatory environment to promote private sector participation in the transport sector and address other policy and institutional issues. In the area of telecommunications, telephone, information technology, internet, and postal service improvements will be addressed, as will the regulatory environment for private sector involvement and the development of the technology for distance education in priority areas.

Urban Management: With Afghanistan's urban population estimated at about 30 percent of the population, this program aims to create cities as viable economic hubs around the country. The program will address rebuilding in cities suffering destruction during the war, the provision of services to housing areas, waste water and sanitation services, new land acquisition for housing as well as attention to policy issues such as town planning and management and standards, procedures and legislation.

Energy and Mining: As in other areas, the power and mining sectors have suffered severe neglect after years of war. The energy and mining program, which recognizes the significant role of the private sector in this area, aims to secure cost effective power supplies to urban areas and the expansion of these power supplies to rural areas where it is cost effective and practical. The role of government will focus on regulation of the sector and development of a policy environment for private sector participation, rather than a directed operational approach.

Natural Resource Management: Focusing on community management of natural resources and improvements in livelihoods, this program will rehabilitate and enhance the development of sustainable agriculture, horticulture and livestock production, including the identification of viable substitutes for poppy production. Resource protection measures will include sustainable water usage and protection of existing forests as well as new planting through agro-forestry programs. Additionally, environmental laws and policies will be developed and awareness campaigns conducted to reach out to the population.

Trade and Private Investment: Private sector development lies at the heart of the government's development plans, and the trade and investment program will lay the basis for developing an environment conducive to foreign and domestic investment. Activities will include assistance for small business development, efforts to improve governance, creation of laws in areas such as competition, direct and foreign investment, and standards and 
certification. The challenging issues of divestiture of state-owned enterprises will also be included.

Public Administration: The Public Administration program focuses on three key areas: the establishment of an effective civil service system, the rehabilitation of the physical infrastructure of government, and the development of an organizational structure that permits the government to deliver the needed goods and services to the Afghan public in an effective manner. The program will also aim to rationalize the number of ministries, ensure that donor assistance is integrated into the budget process, and reduce the number of government corporations. Within this program, an important subprogram will focus on mainstreaming gender through public administration.

Security and Rule of Law: Specific activities relating to security remain under discussion. To address the rule of law, activities will improve the domestic justice system to ensure independence of the judiciary, and will include efforts to rebuild the administration of juvenile justice, prison and law enforcement systems. Among the activities to be carried out are the establishment of new courts and the strengthening of legal aid services within the organization structure of the Supreme Court. 


\section{Annex III.2. Comparison Between Afghanistan's 2002/03 Operating Budget and the Budgets of a Sample of Low-Income Countries ${ }^{64}$}

120. This annex compares the operating budget of Afghanistan for the fiscal year 2002/03 with the budgets of 39 low-income countries supported by an IMF Poverty Reduction and Growth Facility (PRGF) arrangement (24 in Africa, 3 in Asia, 1 in the Middle East, 7 in Eastern Europe, and 4 in Latin America) (Table AIII.1). ${ }^{65}$ Budget numbers are expressed in percentage of GDP and separately show revenue, grants, current expenditure (with identification of the wage bill), and capital expenditure.

121. Table AIII.1 also shows the size of the general civilian government in Afghanistan (in percentage of the population) and compares it to those of other countries in the sample. Consistent with international standards, the general government concept used in this analysis includes both central and local governments, and extra-budgetary funds (such as pensions schemes), but excludes state-owned enterprises. For all the countries in the sample, except for Afghanistan (on which reliable data on the military is not available), civil and military employments are identified separately.

122. For Afghanistan, data on the operating budget and employment levels are drawn from the 2002/03 operating budget as approved on April 6, 2002. For the other countries, the employment data come from a 1997 World Bank Study and the budget numbers are based on an IMF 2002 working paper. ${ }^{66}$ The main findings are the following:

\section{General government employment}

- The civil government employment ratio in Afghanistan (1.1 percent of the population), excluding the army and national security, is comparable to that of lowincome African countries (1.4 percent), but lower than the average for the countries in the sample, excluding Eastern European countries (2.3 percent). ${ }^{67}$

- Data on the size of Afghanistan's National Army and National Security is not available. However, for the other low-income countries of the sample, the weight of armed forces in percentage of the population is shown as reference.

\footnotetext{
${ }^{64}$ Prepared by Thierry Kalfon.

${ }^{65}$ See Table AIII.2 for a list of these countries.

${ }^{66}$ See World Bank (1997) and Gupta et al. (2002).

${ }^{67}$ Including the police.
} 


\section{Budget expenditure and revenues}

- Current expenditure in percentage of GDP is much lower in Afghanistan than the sample's average (11.5 percent compared to 18.5 percent). However the weight of wages in GDP is larger in Afghanistan (7.2 percent).

- $\quad$ Regarding budget revenue, Afghanistan's budget is characterized by a very low level of domestic revenues which, in percent of GDP (2.1 percent), is about one tenth of the average of the selected countries (18.7 percent).

Table AIII.1. Afghanistan: Budget of Afghanistan

Compared to the Budget of Selected Low-Income Countries, 2002/03

\begin{tabular}{|c|c|c|c|c|c|c|c|c|}
\hline & \multirow{2}{*}{\multicolumn{2}{|c|}{$\frac{\text { Afghanistan }}{2002 / 03}$}} & \multicolumn{6}{|c|}{ Low-Income Countries 1/ } \\
\hline & & & \multirow{2}{*}{$\begin{array}{r}\text { Average } \\
3.8\end{array}$} & \multirow{2}{*}{$\begin{array}{r}\text { Africa } \\
1.7\end{array}$} & \multirow{2}{*}{$\begin{array}{r}\text { Asia } \\
2.9\end{array}$} & \multirow{2}{*}{$\begin{array}{r}\begin{array}{c}\text { Middle } \\
\text { East }\end{array} \\
3.8\end{array}$} & \multirow{2}{*}{$\begin{array}{r}\begin{array}{l}\text { Eastern } \\
\text { Europe }\end{array} \\
8.2\end{array}$} & \multirow{2}{*}{$\begin{array}{r}\begin{array}{c}\text { Latin } \\
\text { America }\end{array} \\
2.6\end{array}$} \\
\hline General govt. employment (in percent of pop.) 2/ & $\ldots$ & & & & & & & \\
\hline Civilian government employment 3 / & 1.1 & 4/ & 3.3 & 1.4 & 2.1 & 3.5 & 7.2 & 2.3 \\
\hline Armed forces & $\ldots$ & & 0.5 & 0.3 & 0.8 & 0.3 & 1.0 & 0.3 \\
\hline \multicolumn{9}{|l|}{ Budget (in percent of GDP) } \\
\hline Total revenues & $\ldots$ & & 21.6 & 22.6 & 17.3 & 20.5 & 18.7 & 28.8 \\
\hline Revenues, excl. grants & 2.1 & & 18.7 & 16.8 & 14.2 & 18.5 & 18.0 & 25.8 \\
\hline Tax revenues & $\ldots$ & & 16.1 & 14.5 & 11.5 & 15.0 & 15.8 & 23.6 \\
\hline Nontax revenues & $\ldots$ & & 2.6 & 2.3 & 2.8 & 3.5 & 2.2 & 2.3 \\
\hline Grants & $\ldots$ & & 2.9 & 5.8 & 3.1 & 2.0 & 0.7 & 3.0 \\
\hline Total expenditures & $\ldots$ & & 27.2 & 26.7 & 20.5 & 30.5 & 23.4 & 35.1 \\
\hline Current expenditures & 11.5 & $5 /$ & 18.5 & 16.1 & 10.9 & 22.0 & 19.6 & 23.8 \\
\hline Of which: wages & 7.2 & & 5.6 & 5.8 & 3.5 & $\ldots$ & 4.9 & 8.4 \\
\hline Capital expenditures & $\ldots$ & & 8.7 & 10.6 & 9.6 & 8.5 & 3.8 & 11.3 \\
\hline \multicolumn{9}{|l|}{ Memorandum items: } \\
\hline Population in FY 2002/03 (in millions) & 22.0 & & & & & & & \\
\hline GDP for the FY $2002 / 03$ (in millions of U.S. dollars) & $4,000.0$ & & & & & & & \\
\hline
\end{tabular}

Sources:

- Employment data: World Bank, “An International Statistical Survey of Government Employment and Wages,"

Policy Research Working Paper 1806, Salvatore Schiavo-Campo et al., August 1997.

- Budget dara: IMF, "Expenditure Composition, Fiscal Adjustment, and Growth in Low-Income Countries," IMF Working Paper 02/77, Sanjeev Gupta et al., April 2002.

1/ Based on a sample of 39 low-income countries in Africa, Asia, Middle East, Eastern Europe, and Latin America (see list in Table AIII.2).

2/ Data from a 1997 World Bank Study, mostly based on 1995 and 1996 numbers. Excludes state-owned enterprises.

$3 /$ Central and local governments excluding defense and state-owned enterprises.

4/ Including the police but excluding national security and army.

5/ Operating budget for 2002/03. excluding clearance of wage arrears. 
Table AIII.2. Low-Income Countries Used for Comparison with the Budget of Afghanistan

\begin{tabular}{|c|c|c|c|c|}
\hline Africa & Asia & Middle East & Eastern Europe & Latin America \\
\hline $\begin{array}{l}\text { Benin } \\
\text { Burkina-Faso } \\
\text { Cameroon } \\
\text { Central African Republic } \\
\text { Chad } \\
\text { Djibouti } \\
\text { Ethiopa } \\
\text { Ghana } \\
\text { Guinea } \\
\text { Guinea-Bissau } \\
\text { Kenya } \\
\text { Lesotho } \\
\text { Madagascar } \\
\text { Malawi } \\
\text { Mali } \\
\text { Mauritania } \\
\text { Mozambique } \\
\text { Niger } \\
\text { Rwanda } \\
\text { Sao-Tome and Principe } \\
\text { Senegal } \\
\text { Tanzania } \\
\text { The Gambia } \\
\text { Zimbabwe }\end{array}$ & $\begin{array}{l}\text { Cambodia } \\
\text { Lao P.D.R. } \\
\text { Vietnam }\end{array}$ & Yemen & $\begin{array}{l}\text { Albania } \\
\text { Armenia } \\
\text { Georgia } \\
\text { Kyrgiz Republic } \\
\text { Macedonia } \\
\text { Moldova } \\
\text { Tadjikistan }\end{array}$ & $\begin{array}{l}\text { Bolivia } \\
\text { Guyana } \\
\text { Honduras } \\
\text { Nicaragua }\end{array}$ \\
\hline
\end{tabular}

Sources:

- Employment data: World Bank, "An International Statistical Survey of Government Employment and Wages," Policy Research Working Paper 1806, Salvatore Schiavo-Campo et al., August 1997.

- Budget dara: IMF, "Expenditure Composition, Fiscal Adjustment, and Growth in Low-Income Countries," IMF Working Paper 02/77, Sanjeev Gupta et al., April 2002. 


\section{References}

Afghan Interim Administration, 2002, National Development Framework (March).

Afghan Transitional Administration and Afghan Aid Coordination Agency, 2003, Analysis of Aid Flows to Afghanistan (April).

Ewans, Martin, 2002, Afghanistan. A Short History of Its People and Politics, (Harper Collins).

Gupta, Sanjeev, et al., 2002, "Expenditure Composition, Fiscal Adjustment, and Growth in Low-Income Countries,” IMF Working Paper No. 02/77 (Washington: International Monetary Fund).

Rubin, Barnett R., 2000, Fragmentation of Afghanistan.

Schiavo-Campo, Salvatore, et al., 1997, “An International Statistical Survey of Government Employment and Wages," World Bank Policy Research Working Paper 1806, (August).

United Nations, 2002, Immediate and Transitional Assistance Program for the Afghan People, (February). , 2003, Transitional Assistance Program for Afghanistan, (January).

World Bank, 2002, Afghanistan Support Strategy. , 2003, Transitional Support Strategy (February 7).

World Bank, Asian Development Bank, United Nations Development Program, 2001, Preliminary Needs Assessment, (December). 


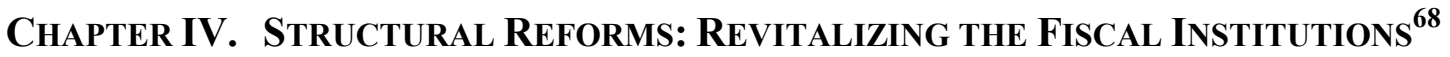

123. The implementation of the fiscal strategy described in Chapter III was underpinned by a comprehensive technical assistance program aimed at restoring essential financial capacity in the Ministry of Finance (MoF) and line-ministries through the design of detailed reform projects, hands-on implementation of these reforms, and training of MoF staff. Specific assistance has also been provided in the areas of civil service reform and private sector development, which are key to maintaining fiscal sustainability.

124. A large number of international organizations and donors are currently involved in these efforts. In particular, following early diagnostic missions in 2002, the IMF outlined specific action plans to establish financial management capacity in the MoF and improve revenue mobilization. The government endorsed these proposals, which are being gradually carried out on the ground by the World Bank, the Asian Development Bank (AsDB), the European Union, the United States, the United Kingdom, and German development agencies (respectively, USAID, DFID, and GTZ), and the U.S. Treasury. The IMF is also assisting the authorities with monitoring progress in the reforms and suggesting further improvements, while hands-on implementation is being undertaken by other international organizations and bilateral donors. In the area of civil service reform, the World Bank is playing a leading role both in the establishment of the civil service commission and the review of the civil service aspects of the overall fiscal strategy. Private sector development is probably the area where there is still considerable scope for further progress and support, especially in relation to the much needed transformation of the large public enterprise sector.

125. Structural fiscal reforms have relied as much as possible on the existing systems, whenever they were found to be sound and reasonably well operated, in order to facilitate ownership of the reforms and yield immediate results. In the areas where revamping the existing system was required, technical assistance efforts primarily focused on getting the basic elements of the financial system right, but also preparing the ground for a gradual introduction of best international practice over the medium to long term. Similarly, particular emphasis has been put on building capacity in the MoF through intensive training and close partnership between the MoF departments and implementing agencies.

\section{Improving Public Expenditure Management: Providing Assurances of TransParenCY AND ACCOUNTABILITY}

126. From the outset, Afghanistan's interim and transitional authorities have committed themselves to full transparency in managing public resources. This theme was articulated in President Karzai's speech during the Tokyo conference in January 2002 and has been reaffirmed as a pillar of the reconstruction strategy since then.

\footnotetext{
${ }^{68}$ Prepared by Thierry Kalfon.
} 
127. Public expenditure management, as performed when the Afghan Interim Administration (AIA) took office, was far from meeting these objectives. Most of the financial management procedures in place before the war and still documented in the financial regulations had broken down: (a) reporting and recording of government's expenditure was non-operational due to the absence of any office automation and communication with the provinces; (b) budget internal controls and external audit had ceased functioning; (c) past banking arrangements for government's operations had collapsed; and (d) cash management and bank reconciliation were no longer performed. As for the fiscal functions which had survived (such as budget execution, some aspects of budget formulation, management of budget appropriations and payroll), they were mostly slow, cumbersome, and subject to both errors and abuse. Apart from the disruptions caused by the conflict, these weaknesses were also the legacy of years of deficit monetization, which removed the discipline of a budget constraint and hence precluded the development of effective financial management procedures. Against this background, a comprehensive program of technical assistance was designed to restore basic financial functions in the MoF.

\section{Budget execution and financial management}

128. Immediate emphasis had to be put on urgently upgrading budget execution and financial management in the MoF in order to provide donors with the fiduciary assurances they requested for realizing their pledges.

129. At the request of the AIA, in June 2002, the World Bank provided grant support for an Emergency Public Administration Project to fund the hiring of qualified international contractors in the areas of financial management, government procurement and audit, with the tasks of (a) assisting the authorities in the performance of these functions; and (b) building local capacities in order to hand over these functions to the authorities as soon as possible.

130. The financial management contractor hired by the government under the World Bank project developed with the treasury a computerized system for expenditure recording, payment processing and financial reporting for budget spending ("Afghanistan's Financial Management Information System" or AFMIS). In order to deliver results immediately, the AFMIS did not change the procedures and functions specified in the Afghan regulations but only computerized the existing manual system using a simple software package. Starting in October 2002, the AFMIS has provided timely and reliable expenditure information on expenditures paid at the center, broken down by the source of funding (domestic revenues or grants), spending units, economic and functional classification; and it has also significantly accelerated the expenditure payments through the automation of the printing of checks. In the initial period, however, this system suffered from important limitations: (a) its coverage was limited to central government expenditures only, excluding revenues and nonwage provincial 
expenditures; ${ }^{69}$ (b) no budget management facilities were available (appropriations, allotments, transfers); (c) expenditure commitments were not recorded; and (d) the system did not perform reconciliation between treasury information and central bank statements. To address these issues, the system's functionalities were significantly expanded at the beginning of 2003/04 to include revenue information, reported provincial expenditures, and budget management functions. Although further improvements are still needed-especially with regards to recording financing sources for the operating budget, bank reconciliation and monitoring the development budget - the introduction of the AFMIS in a very short period of time critically improved expenditure management in the treasury and gave a concrete illustration of the authorities' commitment to fiscal transparency. One of this project's major achievements has been the progressive transfer of the AFMIS operations from the contractor to Afghan staff following intensive training and capacity-building.

131. In addition to the support provided to the MoF under the World Bank Emergency Public Administration project, the authorities have recently taken important steps to improve budget execution and reporting in the provinces. This task, which has received priority attention since the beginning of 2003/04, aims at moving away from the current impasse where (a) provinces do not report their nonwage expenditures to the center; and (b) the center, in the absence of provincial expenditure reports, refuses to transfer resources to the provinces. To do so, forty Afghan fiscal advisors have been trained in the MoF under USAID funding and sent to all provinces to assist them with financial reporting on both their revenues and expenditures. Six of them were assigned to the six provinces collecting the bulk of domestic revenues ${ }^{70}$ to coordinate the activity of the other provincial advisors. Similarly, satellite communication facilities will be set up on a pilot basis in the largest of these provinces to facilitate exchange of information between the MoF and its regional offices (Mustufiats). The rolling out of AFMIS to the provinces has recently started and Herat's Mustufiat is expected to be the first to use the system (by the beginning of October 2003). These initiatives have started yielding important and tangible results: in particular, whereas the Mustufiats did not report on their nonwage expenditures in 2002/03(Chapter III), they have started doing so in 2003/04. However, fiscal reporting still requires improvement, especially on revenues, as there are solid indications that major provinces report less revenues than they collect and most provinces send their reports to the center with significant delays. ${ }^{71}$ The progressive consolidation of the provinces' accounts into the accounts of the central government will help to address these issues (see next section).

\footnotetext{
${ }^{69}$ For the latter, although the system had the technical capacity to record and account for nonwage provincial expenditures, no reliable information was received at the center on this category of expenditures in 2002/03.

${ }^{70}$ Herat, Nangarhar, Kabul, Kunduz, Mazar-i-Sharif, and Kandahar.

${ }^{71}$ At the end of the sixth month of 2002/03, a large number of provinces had not reported their revenues for the fourth month (see Table III.3 in Chapter III)
} 


\section{Cash management and banking arrangements}

132. Management of government cash resources is universally regarded as one of the central responsibilities of the MoF treasury. Cash management is a critical element of public resource management, especially in environments characterized by high demands on scarce public revenues. Government banking arrangements exert a strong influence on the ability of the treasury to effectively discharge its cash management responsibilities. Learning from international experience, most governments have opted for concentrating all government cash resources in a single bank account (the "Treasury Single Account", or "TSA") to strengthen treasury control over cash flows, reduce the cost of borrowing operations, and minimize idle cash balances.

133. While in theory Afghanistan was supposed to operate with a "TSA," there has been, in practice, a proliferation of accounts in recent years that interferes with proper consolidation of cash resources, hinders prompt information on the government's fiscal situation and leads to fragmentation of the budget revenues. The IMF has submitted to the authorities a progressive plan to consolidate the government's accounts in the center and the provinces and eliminate the accounts of line-ministries which do not serve the public interest. In line with these recommendations, the authorities streamlined the number of MoF's bank accounts operated at the center for domestic revenue and expenditures. ${ }^{72}$ Most importantly, they recently undertook a complete overhaul of the government's banking arrangements in the provinces to improve revenue centralization. In August 2003, the treasury instructed the central bank to close all the provinces' accounts and transfer their balances into two new accounts, one for expenditures and one for revenues, the latter being operated on a "deposit basis" only, meaning that provinces will no longer be authorized to draw on their revenue account to spend without explicit authorization from the MoF. The next step will involve ensuring regular consolidation of these accounts into the central government's accounts and making timely transfers to the provincial accounts to allow provinces to make their expenditures according to their budget allotments.

134. The treasury does not currently undertake cash or financial planning. As a result, the MoF cannot inform the central bank of its in-year cash requirements, nor can it request donors to adjust their disbursement schedule according to government's cash projections. This results in a lack of predictability in the resources made available to line-ministries, leading to delays and inefficiencies in budget execution. To address this issue, the treasury has recently established a cash-management unit charged with the responsibility for estimating revenue inflows, forecasting future disbursements, and developing an in-year cash-plan. However, the development of a full-fledged cash planning regime can only be envisaged in the medium term since this is a highly technical task, which will first require

\footnotetext{
72 The number of these accounts was reduced from 26 to 2 excluding the specific accounts opened to track donor funded expenditures.
} 
full introduction of a TSA and will need to be supported by extensive dedicated technical assistance.

\section{Budget formulation}

135. Significant support has been offered to the MoF and line-ministries for the preparation of the 2002/03 and 2003/04 budgets. The budget preparation for 2003/04 marked a vast improvement over the procedures followed in 2002/03 reflecting major efforts by the Cabinet, MoF, and line-ministries toward information compilation, strategy formulation, prioritization, and coordination. However, further progress is needed in terms of better integration between the ordinary and development budgets, quality of budget submissions by the line-ministries, revenue projection, construction of the macrofiscal framework to underpin the initial budget estimates, introduction of hard budget constraints at the beginning of budget preparation, and development of a medium-term fiscal framework.

136. Various donors have assigned a number of resident budget preparation experts to the $\mathrm{MoF}$, whose tasks - in addition to hands-on support during the budget preparation processfocus on training, capacity building, and restructuring of the MoF Budget Department. This assistance, which has mainly dealt with the ordinary budget so far, has recently been expanded to the development budget, with the establishment of a development budget unit in the treasury supported by a budget resident advisor. Similarly, chief financial officers funded by the World Bank will be appointed to key line-ministries to enhance their budget formulation (and execution) capacities.

137. The IMF also intends to provide short-term technical assistance to assist the MoF with the establishment of a macrofiscal coordination unit, which will be responsible for coordinating macroeconomic forecasting and analysis with the central bank, Central Statistics Office (CSO), and other government agencies, making recommendations on fiscal and tax policy, and providing input into the budgetary process.

\section{Coordination of external assistance}

138. In a context where budget financing comes mainly from external sources and where a large number of multilateral and bilateral donors are involved in the reconstruction efforts, coordination of donor resources is of critical importance. The main instrument used by the authorities to avoid duplication of efforts and overlapping of donor projects, has been the preparation and adoption of the National Development Budget (NDB) through which most of the donor assistance has been channeled (Chapter III). In addition, the authorities established on April 1, 2002, the Afghan Aid Coordination Agency (AACA) as a public body within the government, to track the disbursement of foreign aid. The AACA's primary activities include: (a) coordinating development efforts from bilateral and multilateral donors; (b) reviewing and endorsing projects and programs carried out by multilateral/bilateral agencies and nongovernmental organizations; (c) developing a comprehensive information system for tracking foreign assistance and monitoring development investments and programs; and (d) serving as secretariat for the Consultative Groups set up within the NDB. 
The AACA's main achievement since its creation has been the development of a comprehensive donor information database recording the pledges, commitments, and disbursements from all donors. ${ }^{73}$

139. In addition, in December 2002, the MoF established (with the support of the World Bank) a Grant Management Unit (GMU) within the treasury which is responsible for assuring that donor contributions are utilized as specified in the grant agreements and reported accordingly. The GMU will act as the repository and custodian of all grant agreements, authorize off-shore payments when government spending will not be channeled through the budget, maintain payment records, and report to donors and the MoF. The GMU is in its infancy and it is too early to determine what the real scope of its interventions will be, as the authorities have apparently decided to merge the GMU and AACA functions into a new department to be established in the MoF.

\section{Reforming Revenue Policy and Administration: Enhancing Domestic REVENUE COLLECTION}

140. Improving revenue mobilization is key to attaining fiscal sustainability. Afghanistan's operating expenses cannot be expected to be funded by donors' grants indefinitely and the bulk of external assistance will increasingly be allocated to development expenditures. The authorities therefore aim to fully finance the ordinary budget through domestic revenues by 2006. Meeting this ambitious objective will require increasing revenue collection from about $\$ 130$ million in $2002 / 03$ to about $\$ 600$ million in $2006 / 07$. This will not be possible without a major overhaul of the tax and customs legislation and a large-scale reform of tax and customs administration. At the request of the AIA, the IMF helped the authorities in June 2002 to design a reform program in these areas, which is being progressively implemented with the assistance of international and bilateral donors.

\section{Customs policy and administration}

141. As customs duties account for more than half of total domestic revenue collection, improving customs policy and administration has been one of the authorities' top priorities. The 1974 customs law specifies the import duties, fees, and charges levied on international trade and transactions. The customs tariff includes 25 tariff bands with rates ranging from 7 percent to 150 percent allocated across 888 tariff headings (for an unweighted average tariff rate of 43 percent). ${ }^{74}$ Duty is currently calculated on the c.i.f. Afghan value of imported goods, using artificially low exchange rates of Af 2 per U.S. dollar to Af 4.5 per U.S. dollar - compared with a market rate of about Af 48 per U.S. dollar (Box IV.1). In addition to the customs duties, there are a number of fees levied on imports, especially a

\footnotetext{
${ }^{73}$ This database is publicly available and can be accessed at the following website: http://www.af/dad.

74 Due to the lack of data (no historic import data sorted according to tariff codes are currently available), it is very difficult to assess the tariff structure, the extent of exemptions, and their impact on revenues.
} 
2.5 percent fee collected by the Chamber of Commerce for the valuation of imported goods (customs valuation is not currently performed by the customs administration but by the Chamber of Commerce). Although there is no excise tax, customs tariffs achieve the same result by imposing higher tariffs on certain goods that are not produced domestically and would normally be excised (automobiles, tobacco products). Imports of petroleum, diesel, and kerosene for transportation purposes are exempt from duty. ${ }^{75}$

\section{Box IV.1. Exchange Rates Currently Used in Customs Valuation}

A variety of different exchange-rates are currently used by various public institution for customs valuation. These rates have in common to be fixed at very low levels compared to the market exchange rate (about Af 48 per U.S. dollar).

- Chamber of Commerce: Af 3.5 per U.S. dollar;

- Herat Customs: Af 2 per U.S. dollar;

- Kabul Customs: Af 4.5 per U.S. dollar;

- Kandahar Custom: Af 2.5 per U.S. dollar.

It seems that only Kabul airport applies the market exchange rate but only on certain categories of goods (including TVs and clothes imported by individuals).

142. The use of different and artificially low exchange rates for customs valuation distorts the value of international trade, has a negative impact on revenue collection and creates uncertainty for traders and confusion for customs officers. Similarly, the extremely complex tariff structure is difficult to administer and is subject to corruption and abuse. In line with the IMF's June 2002 recommendations, the MoF has prepared a draft presidential decree recommending the revision of the customs law with a view to (a) mandate the use of the market exchange rate of the Afghani in customs valuation; (b) reduce the number of tariff bands from 25 to $4 ;^{76}$ and (c) lower the tariff rates from the current range of 0 to 150 percent to rates ranging from 0 to 20 percent. The streamlining and reduction of the tariff rates will partly offset the effect of the adoption of the market exchange rate on the average level of customs duties. This draft decree has been already extensively discussed with the interested parties (merchants and traders), who apparently received it favorably. Its adoption by the Cabinet is now imminent.

\footnotetext{
${ }^{75}$ However, there appears to be a "monopoly tax" on petroleum products equal to 20 percent of the import value.

${ }^{76}$ Zero, 5, 10, and 20 percent.
} 
143. These customs policy reforms, which are key to enhancing revenue collection, will not be successful unless enforced by a capable and effective customs administration. However, customs administration is currently weakened by a lack of experienced managers, poorly trained staff, inadequate facilities and equipment, and outdated and cumbersome policies and procedures, all of which create avenues for potential corruption and abuse. In particular, customs regulations are apparently not applied consistently throughout the country and, in some cases, customs duties are "negotiated" between taxpayers and customs officers. Building on the June 2002 IMF recommendations, the authorities prepared-and adopted on July 4, 2003-a decree to immediately simplify customs procedures. The provisions of this decree include the (a) adoption of the internationally recognized "single administrative document" for customs clearance; (b) improved monitoring of exemptions; (c) progressive introduction of the harmonized tariff codification for commercial goods; (d) development of a comprehensive computerized data base for customs valuation; (e) establishment of a simplified customs regime for travelers; (f) licensing by the MoF of "customs brokers" to assist traders with the clearance of commercial goods; $(\mathrm{g})$ the assignment of a taxpayer identification number (TIN) for each tax payer; and (h) gradual phasing out of the Chamber of Commerce involvement in customs valuation. ${ }^{77}$ In addition, the Afghan Transitional Administration (ATA) has designed a comprehensive five-year plan to strengthen the administration of customs. This strategic document calls for a complete revamping of the customs department and its regional offices, training of customs officials, reform of customs procedures (including investigation, enforcement and controls), centralization of customs revenues collected by the provinces, and progressive rehabilitation of customs infrastructure, equipment, and communications. This plan covers the years 2003-3007 and has an indicative cost of around US\$100 million, of which two thirds would be allocated to technical assistance. The opening in May 2003 at Kabul airport of a model customs house, featuring a renovated warehouse and training facilities, has been a first step towards the implementation of this strategy and the authorities plan to extend this pilot to all provinces by the end of 2003/04.

\section{Tax policy and administration}

144. Around half of the domestic revenues collected in 2002/03 are noncustoms tax revenues. Therefore, improving revenue mobilization will require-in addition to reforming customs - the establishment of a fair, transparent, and easy to administer tax system.

145. The existing tax regime is defined in the 1965 income tax law which provides for a progressive personal income tax (PIT) with rates varying from 4 percent to 60 percent, a flat 20 percent corporate income tax (CIT), a 2 percent business receipts tax (a form of sales tax on corporate entities' turnover), withholding taxes on imports and exports, and various fixed (presumptive) taxes (Annex IV.1). It is currently difficult to ascertain all the details of the 1965 tax law and its application, since the law has been amended by 18 separate decrees and

\footnotetext{
${ }^{77}$ And full transfer of this function to the customs administration.
} 
not all amendments have been included in a comprehensive consolidated version. In addition, tax administrators in the MoF and its financial regional offices (Mustufiats) have different views about the applicable tax provisions, which are not applied consistently throughout the country. In particular, a Taliban decree of May 1999 seems to have reformed the personal income tax to introduce three rates of taxation $(1,8$, and 20 percent) together with a series of exemptions. It is unclear if these provisions are still currently enforced.

146. The tax law includes a number of serious deficiencies:

- The current rule imposing taxation of worldwide income on Afghan citizens wherever they live, leaves a large number of expatriate Afghans intending to return to Afghanistan with a potentially crippling legal tax liability on all the income they earned abroad. This tax provision creates disincentives for these individuals to return to Afghanistan and participate in the country's reconstruction;

- $\quad$ The top marginal rate for PIT (60 percent) is too high compared to international standards and cuts in at modest annual earnings level (less than half of the average annual salary), which hampers voluntary tax compliance and leads to massive tax fraud. In addition, the existing 32 tax rate structure is complex and difficult to administer;

- $\quad$ The coverage of the business receipts tax does not include certain services provided to expatriates and other high-income earners, resulting in revenue losses for the government;

- $\quad$ The current limitations of the loss carryover period and depreciation allowances for the payment of the CIT discourage investment. Liberalization of these regimes should be used to stimulate new investment.

147. In view of these deficiencies, the authorities are committed to amending the income tax law in order to improve the efficiency and equity of the tax system. In line with the IMF June 2002 recommendations, and with the support of resident tax advisors, the ATA is now preparing draft decrees to (a) impose the income tax on the basis of whether an individual is a resident or nonresident of Afghanistan; (b) reduce the top marginal tax rate for individuals from 60 to 25 percent and increase the personal exemption; (c) restore wage withholding on higher-income employees; (d) introduce a rent tax and an airport departure fee; (e) expand the business receipts tax to cover certain services most likely to be provided to expatriates and other high income-earners, ${ }^{78}$ (f) extend the loss carryover period; and (g) liberalize the depreciation allowances allowed for tax purposes.

\footnotetext{
${ }^{78}$ Hotels, restaurants, telecommunications, rental vehicles.
} 
148. These tax policy reforms are closely linked to a program to strengthen the capacity of the revenue department in the MoF and improve tax operations in the Mustufiats. This plan includes the establishment of a large taxpayer unit (LTU) in Kabul by the end of 2003, responsible for administering the personal income tax ${ }^{79}$, the business receipt tax and the rent tax. The Kabul LTU will then be complemented by model tax offices for medium-sized tax payers, in which new operational procedures and concepts would be piloted.

149. Although initial steps have been taken by the authorities to reform tax policy and administration, progress has been somewhat slower than in customs, due to the priority given by the authorities to the customs reform, limited technical expertise in the MoF, and the Cabinet's reluctance to adopt a tax reform with potential vast social implications without an in-depth understanding of all its elements. However, a sizeable amount of technical assistance has been recently mobilized and decisions are expected to be reached by the Cabinet in this area by the end of 2003.

150. Without underestimating the burden put on the scarce MoF capacities by the finalization of the customs reform, it is essential that tax and customs reforms be closely coordinated. In addition, the revenue policy reforms envisaged by the authorities will not ease the pressures on the financing of the ordinary budget unless provinces, which collect most of the tax and nontax revenues, transfer their revenues to the center on a timely and regular basis. In this regard, the agreement recently reached with the provincial governors on this issue, is an important step toward effective centralization of revenues and improvement of revenue collection (see Chapter III).

\section{Revitalizing The Civil Service}

151. The underlying arrangements for government employment stem from the 1970 law on the "Status and Condition of Government Employees" as amended by the 1977 decree on the civil service, which provides for a system of centralized recruitment, job classification, grading, and pay. Although this legislation includes a number of sound provisions, in reality Afghanistan's civil service is in a state of profound crisis. Its situation can be characterized as follows:

- $\quad$ Large uncertainties about the size of the public service; it has been very difficult to ascertain the number of staff employed by the government, due to the absence of a nominal roll of employees and large variations in the number of staff paid each month. These difficulties were compounded by the failure of payroll data to indicate in which ministry provincial staff worked or to distinguish between staff working in ministries and those working in government enterprises. As a result, estimates for total civilian employment range widely from 240,000 to 331,000 , excluding military personnel (about 100,000) and government enterprises (about 35,000). In addition, little is known about the status, competence and efficiency of the civil service.

\footnotetext{
${ }^{79}$ As prescribed in the May 1999 Taliban decree until the tax law is amended.
} 
- A serious lack of professional capacity; although the size of the civil service is not large relative to the population (1.4 percent of the population excluding state-owned enterprises (SOEs) and military), numbers are still out of proportion to the minimal services actually delivered. The low level of service reflects the very weak capacities in the ministries, with overrepresentation of unskilled workers in the government's workforce and the absence of qualified senior staff, most of whom emigrated during the war.

- $\quad$ Pervasive patronage; the AIA inherited a situation where a large number of civil servants had been hired on the basis of their ethnic origins and loyalty to the successive factions that ruled the country, rather than their proven professional qualifications.

- Inappropriate pay arrangements; the current pay and grading system is inadequate to attract, retain and motivate skilled civil servants:

$\circ$ The average monthly pay for civil servants is approximately Af 1,800 (about $\$ 36$ at current exchange rates). This is probably higher than market rates for unskilled staff, but is clearly well below what would be needed to retain or recruit qualified senior civil servants. Low salaries for public servants increases their vulnerability to corruption, especially among those working with the private sector (for example, customs);

- The wage structure is extremely compressed, as food allowances comprise the bulk of total pay. The vast majority of government staff are paid approximately the same monthly salary of Af 1,800 . The salary compression was recently exacerbated by the introduction of an additional flat rate food allowance on May 5, 2002.

- The government's ability to manage its workforce has been hampered by the extensive practice by some donors and NGOs to pay large "salary top-ups" to Afghan civil servants working on externally supported projects. This has distorted the public and private sector pay market and created resentment from the staff who have not benefited from these arrangements.

- $\quad$ Fragmented and duplicated government structures; a number of public institutions are remnants of the old centrally-planned economic model and their existence is no longer justified in a market-based economy. Similarly, in the past, the rationale for creating a number of government bodies was based on the need to grant official positions to powerful individuals and factions rather than providing specific public services to the population. This has resulted in the fragmentation of government structures and the unnecessary overlapping of many public functions. 
152. In view of all these problems, the reform of public administration and civil service has been deemed critical to Afghanistan's development and has therefore been made a priority in the reform agenda by both the authorities and donors. The World Bank has provided the authorities with significant technical assistance in this area.

153. An important step in the modernization of the civil service was the establishment, in June 2002, of the Administrative Reform and Civil Service Commission (ARCSC), the creation of which was an obligation of the government under the Bonn agreement. The commission's main responsibilities have been recently set out in a presidential decree (June 10, 2003). These responsibilities include: designing and implementing the civil service management policies and procedures; coordinating the public administration reform program; recruiting government senior staff on the basis of a fair, transparent, and open process; and overseeing lower level appointments in the civil service. However the specific delineation of responsibilities between the ARCSC, the MoF, the Ministry of Labor and Social Affairs, and the Office of Administrative Affairs is not yet fully clarified. In particular, it remains to be seen if the ARCSC responsibilities will cover all—or only part of - the tasks usually assigned to a civil service management agency, including the establishment of a register of government's sanctioned positions; oversight of personnel records; development and maintenance of a human resource database; workforce planning; job classification and grading; and pay policy.

154. The authorities have presented in the 2003/04 NDB a detailed short-term strategy for public administration and civil service reform, aiming at creating a lean, capable and motivated civil service dedicated to supporting the country's national interests. This strategy focuses on the following elements: (a) drafting a new civil service law and subsidiary regulations governing civil service employment; (b) revising the pay and grading arrangements on a pilot basis; (c) developing a nominal roll for civil servants; (d) introducing a comprehensive government payroll system in the treasury; (e) reviewing ministerial staff and structures; (f) starting preparatory work for future retrenchment arrangements; and (g) individualizing salary payments. ${ }^{80}$ The government is also committed to improving the timeliness of provincial salary payments and implementing effective arrangements for enforcing civil service headcount ceilings mandated in the annual budget.

155. Although fully aware of the central role of the civil service reform in the reconstruction process, the authorities have emphasized that this reform is faced with considerable difficulties. It will take time and should be carried out with caution due to its potential large economic and social implications. In particular, any across-the-board pay reform should remain compatible with medium-term fiscal sustainability. Moreover, detailed proposals for salary decompression remain contingent on a reliable classification of individual positions in the government, which is a lengthy and resource-demanding process

\footnotetext{
${ }^{80}$ Currently, salary checks are not cashed by the individuals: the managers of the spending units cash a check issued by the treasury, accounting for the salaries of his subordinates and distributes the cash to his staff.
} 
that has not started yet. The implementation of a retrenchment program is a highly sensitive political issue since civil service employment continues to serve as a social safety net for a large part of the urban population; also, this program cannot be implemented without prior development of a nominal payroll and effective establishment controls to avoid the dangers of staff leaving and then reentering the civil service.

156. Under these constraints, progress in the civil service reform was modest in $2002 / 03 .{ }^{81}$ However, important initiatives have been recently taken, including the approval by the Cabinet on July 10, 2003 of a presidential decree ("Priority Restructuring and Reform Decree") introducing an interim additional salary allowance for specific positions in ministerial departments which are considered critical for reform (e.g., customs, tax) and are undergoing a large-scale restructuring of their functions. A number of departments have already submitted applications to the ARCSC to benefit from the provisions of the new decree, including customs and treasury in the MoF. A second decree will soon be submitted to the Cabinet to regulate and limit the salary top-ups granted by donor agencies. IMF staff and other bilateral and multilateral donors have underscored that the recent pace in the civil service reform will need to be sustained to meet the ambitious objectives set up in this area in the 2003/04 NDB.

\section{Developing the Private Sector: Building a Market-Led Economy}

157. Afghanistan has a long tradition of entrepreneurship and a vibrant private sector, which has actively engaged in agricultural production, trading activities, and small-scale industrial activity for centuries. In the $1980 \mathrm{~s}$, the development of the private sector was hampered by the preference given to an economic model based on state intervention and was further undermined subsequently by war, devastation and neglect. The first condition to restoring Afghanistan's business vitality is to consolidate security and political stability throughout the country. Equally important is the establishment of a strong judicial system able to effectively enforce laws and regulations. Energizing the private sector also requires the building of a legal framework which would provide for fair, transparent, and simple rules for the operations of corporate entities, especially with regard to the banking system, tax and customs, competition protection, property registration, and foreign investment.

158. Important steps have been taken by the authorities in this direction, including the preparation of draft banking and central banking laws (Chapter VI), successful implementation of the currency conversion (Chapter V), formulation of a large-scale customs reform (above), and enactment of a new domestic and foreign investment law (below).

159. In August 2002, the ATA replaced the 1987 law on domestic and private investment with a new law dropping the provisions of the previous system, which had exerted a negative impact on foreign direct investment, including joint venture requirements, minimum Afghan

${ }^{81}$ Apart from the decrees establishing the civil service commission and its functions. 
capital requirements, and limitations on repatriation of profits. The new law also provides three to seven year tax holidays to eligible companies, according to the type of investments, as well as a four-year exemption from exports tariffs and duties. Under the law, a High Commission on Investment, chaired by the Minister of Commerce ${ }^{82}$ is responsible for all policy decisions regarding domestic and foreign investment, and an Office of Private Investment (OPI), established within the Ministry of Commerce, determines which investments qualify for tax holidays. The authorities' decision to scrap the obsolete 1987 law was a critical step toward the development of foreign private investment in Afghanistan. However, the use of tax holidays as a tool for encouraging capital inflows, is questionable. International experience has shown that such exemptions reduce the transparency of the tax system, hamper the efficiency of tax administration, and significantly erode the tax base, which may have a detrimental impact on revenue collection in the medium term. The IMF generally counsels against the use of tax holidays, and recommends instead more transparent mechanisms for encouraging investment, such as low corporate tax rates, accelerated depreciation regimes and liberal loss carry forward rules. Following these recommendations and those from other donors, the August 2002 law is now being reviewed by the authorities with consideration of elimination of tax holidays.

160. The government has taken steps in attracting investment in major areas, including the sale of a telecommunications license in October 2002, and the signing of public contracts with international developers to renovate two major hotels in Kabul.

161. In addition to stimulating foreign investment, the transformation - through partial/total privatization or closing down - of the extensive SOEs network is a critical element of Afghanistan's transition to a market economy. Such a reform would eliminate the burden placed on the ordinary budget to support these enterprises, ${ }^{83}$ restore a level playing field between these enterprises and potential private sector competitors, and reduce the scope for corruption. Preliminary data suggest that, from the 174 public enterprises which were operated under the communist regime (and accounted for more than one-third of the revenues of the ordinary budget ), only 80 have survived (or 161, including their provincial branches) accounting for a total of somewhat more than 35,000 employees. Very little information is currently available on their situation and operations. Only a small number of SOEs seem to be viable; none are self-sufficient - let alone profitable - and for most of them, their employee salaries are fully paid out of the government's ordinary budget. The main SOEs are the public utility companies (for example, electricity and gas production and distribution) some of which apparently have partial success in collecting utility fees, but only in major urban centers. ${ }^{84}$ Other important SOEs include fabric making companies and small-scale cement industries.

\footnotetext{
${ }^{82}$ And comprising the ministers of finance, justice, foreign affairs, planning and reconstruction, as well as two representatives of the private sector.

83 About $\$ 52$ million has been appropriated in the 2003/04 budget to fund SOEs.

84 Ariana Airlines, the Afghan national airline, does not have the status of a public enterprise.
} 
162. The authorities have officially indicated that that they do not intend to revitalize nonfunctioning public enterprises and they plan to close them down or divest them to the private sector whenever possible. A Commission for the Evaluation of the State-Owned Enterprises was established in June 2002 and started operating in January 2003. Its main activities include the assessment of SOE operations and assets, preparing recommendations for privatization, and drafting of transparent privatization procedures. Its activities so far have been mainly limited to a census of the existing SOEs. Notwithstanding their commitment to an ambitious overhaul of the public sector, the authorities have acted cautiously in this area for the following reasons: (a) most records of SOE assets have disappeared, making it extremely difficult to design any privatization strategy; (b) there has been reluctance on the part of the government to rush into a privatization process which, without appropriate assurances and safeguards, could create considerable opportunities for corruption; (c) line-ministries have been reluctant to delegate the transformation of the enterprises operating in their sector to the newly created Commission for the Evaluation of SOEs; and (d) this is a highly technical area in which major technical assistance is required and no such assistance has materialized yet. Significant progress in this area is unlikely without strong support from the international community. 


\section{Annex IV.1. Pay Structure for Government Staff}

There are two pay scales for government staff in Afghanistan - one for permanent staff (karmand) and one for "contract" (agir) staff. Karmand are regular, permanent public employees, whereas agir are hired on fixed term contracts. The base pay scales are very similar. The same monetary allowances apply to both, but teachers, whether karmand or agir, do not receive the second food allowance introduced on May 5, 2002. The different elements of the civil servants salaries are the following:

\begin{tabular}{|c|c|}
\hline Base pay & Payable to all staff \\
\hline Food allowance & Payable to all staff \\
\hline Second food allowance & Introduced in May 5, 2002. Not payable to teachers. \\
\hline Transport allowance & Payable only to public employees in Kabul. \\
\hline Professional allowance & $\begin{array}{l}\text { The amount of this allowance varies according to } \\
\text { the level of education: } \\
\text { - Af } 8 \text { for those who have completed high } \\
\text { school; } \\
\text { - Af } 15 \text { for a university degree; } \\
\text { - Af } 17.5 \text { for an additional year beyond } \\
\text { university; } \\
\text { - Af } 20 \text { for a master's degree; } \\
\text { - Af } 25 \text { for a doctorate. }\end{array}$ \\
\hline Additional professional allowance & $\begin{array}{l}\text { Only payable to permanent staff at the highest level } \\
\text { of the pay scale. }\end{array}$ \\
\hline Scientific allowances & $\begin{array}{l}\text { Only payable to permanent staff at the highest level } \\
\text { of the pay scale. }\end{array}$ \\
\hline Special allowances & \\
\hline
\end{tabular}


Annex IV.2. Tax Summary

(As of August 2003)

\begin{tabular}{|c|c|c|c|}
\hline Tax & Rate & Taxable base & Remarks \\
\hline $\begin{array}{l}\text { Corporate income } \\
\operatorname{tax}(\mathrm{CIT})\end{array}$ & Flat rate of 20 percent. & $\begin{array}{l}\text { Net profits of } \\
\text { corporations and limited } \\
\text { liability companies. }\end{array}$ & $\begin{array}{l}\text { - Most expenses incurred to derive gross income are deductible. } \\
\text { - Firms are allowed to deduct losses incurred in previous years. } \\
\text { - The CIT is mostly collected in the form of withholding taxes on } \\
\text { imports and exports creditable against the income tax (see below). }\end{array}$ \\
\hline $\begin{array}{l}\text { Personal income tax } \\
\text { (PIT) }\end{array}$ & $\begin{array}{l}\text { Progressive schedule comprising } \\
21 \text { brackets, with rates varying from } \\
4 \text { to } 60 \text { percent. }\end{array}$ & $\begin{array}{l}\text { Income of employees } \\
\text { (salaries and wages) and } \\
\text { profits of noncorporate } \\
\text { entities. }\end{array}$ & $\begin{array}{l}\text { - The basis for taxation is Afghan citizenship. The tax is imposed on } \\
\text { the worldwide income of Afghan citizens wherever they live. } \\
\text { - The wage PIT which used to be collected on government and } \\
\text { private sector employees (wage withholding tax) seems to have } \\
\text { disappeared at the beginning of the 1990s. Most of the PIT is now } \\
\text { collected in the form of fixed presumptive taxes levied on } \\
\text { individuals (see below). }\end{array}$ \\
\hline $\begin{array}{l}\text { Business receipts tax } \\
\text { (BRT). }\end{array}$ & $\begin{array}{l}\text { Two rates: } \\
\text { - } 2 \text { percent: gross receipts of legal } \\
\text { persons engaged in domestic } \\
\text { business. } \\
\text { - } 2 \frac{1}{2} \text { percent: receipts of legal } \\
\text { persons engaged in import and/or } \\
\text { export operations. }\end{array}$ & $\begin{array}{l}\text { Gross receipts (before } \\
\text { any deductions) of } \\
\text { corporations and limited } \\
\text { liability companies. }\end{array}$ & $\begin{array}{l}\text { - The BRT comes in addition to the CIT on taxable profits. } \\
\text { - The BRT must be paid within } 6 \text { months of the end of the fiscal } \\
\text { year, irrespective of whether the business makes a profit or a loss. } \\
\text { - Imports are not taxed under the BRT but exports are. } \\
\text { - The BRT raises greater revenue than the CIT. }\end{array}$ \\
\hline $\begin{array}{l}\text { Fixed withholding } \\
\text { taxes on imports and } \\
\text { exports (creditable } \\
\text { against the income } \\
\text { tax). }\end{array}$ & $\begin{array}{l}\text { - Imports: } 4 \text { percent for licensed } \\
\text { importers and } 3 \text { percent for } \\
\text { unlicensed importers. } \\
\text { - Exports: } 4 \text { percent for licensed } \\
\text { exporters and } 2 \text { percent for } \\
\text { unlicensed exporters. }\end{array}$ & $\begin{array}{l}\text { - Unincorporated } \\
\text { exporters or } \\
\text { importers. } \\
\text { - The tax is based on } \\
\text { the duty-paid cost of } \\
\text { imports/exports. }\end{array}$ & \\
\hline
\end{tabular}


Tax Summary (concluded)

(As of August 2003)

\begin{tabular}{|c|c|c|c|}
\hline Tax & Rate & Taxable base & Remarks \\
\hline $\begin{array}{l}\text { Presumptive taxes in } \\
\text { lieu of the income } \\
\text { tax. }\end{array}$ & $\begin{array}{l}\text { - Retailers: based on a } 170 \text { category } \\
\text { classification of businesses. Taxation } \\
\text { depends on the types of goods sold, the } \\
\text { size and location of businesses. } \\
\text { - Limited list of specific businesses (for } \\
\text { example, cinemas, theaters, mills). } \\
10 \text { percent on estimated turnover. } \\
\text { - Transportation businesses (taxis, } \\
\text { buses,...). Lump sum depending on the } \\
\text { type, size, and characteristics of the } \\
\text { vehicles used. } \\
\text { - Government contractors. From } 1 \text { to } 8 \\
\text { percent of the price of the goods and } \\
\text { services purchased by the government. }\end{array}$ & $\begin{array}{l}\text { Estimated gross } \\
\text { receipts of } \\
\text { corporations and } \\
\text { limited liability } \\
\text { companies (except } \\
\text { importers and } \\
\text { exporters). }\end{array}$ & $\begin{array}{l}\text { The major reasons for using presumptive taxation in lieu of income } \\
\text { tax are simplification, reducing compliance costs for the tax payer } \\
\text { and the tax administration, and combating tax evasion. }\end{array}$ \\
\hline Import duties & $\begin{array}{l}25 \text { tariff bands with rates ranging from } \\
7 \text { percent to } 150 \text { percent allocated across } \\
888 \text { tariff headings. }\end{array}$ & $\begin{array}{l}\text { C.i.f. in Afghani } \\
\text { value, using an } \\
\text { exchange rate of } \\
\text { Af } 4.5 \text { per } \\
\text { U.S. dollar. }\end{array}$ & $\begin{array}{l}\text { - Customs tariffs currently in use were introduced in } 2000 \text {. } \\
\text { - Imports of petroleum, diesel and kerosene for transportation } \\
\text { purposes are exempt from duty. } \\
\text { - The exchange rate used for valuation purpose is well below the } \\
\text { open market rate (approximately Af 38-40 per U.S. dollar). }\end{array}$ \\
\hline Fees and charges & $\begin{array}{l}\text { - Chamber of Commerce license and } \\
\text { valuation of imports/exports: } \\
2.5 \text { percent } \\
\text { - Red Crescent fee: } 2.5 \text { percent. } \\
\text { - Ministry of Commerce's permit fees } \\
\text { (e.g., cars } \$ 200 \text { to } \$ 400 \text {, cigarettes } \\
\$ 2.5 \text { per case). }\end{array}$ & $\begin{array}{l}\text { For the Chamber of } \\
\text { Commerce and the } \\
\text { Red Crescent: c.i.f. } \\
\text { invoice value of } \\
\text { exports or imports. }\end{array}$ & $\begin{array}{l}\text { In addition to customs duties, there are numerous fees, charges, and } \\
\text { other taxes levied on imports and exports that add significantly to } \\
\text { the cost of international trade. }\end{array}$ \\
\hline
\end{tabular}

1/ A type of partnership.

2/ For unlicensed importers, this tax is not creditable against the income tax.

3 / For unlicensed exporters, this tax is not creditable against the income tax.

4/ If they are incorporated, they only pay the CIT.

5/.In a presumptive tax, the concept of income tax base is replaced by indicators that are more easily measured. 


\section{Reference}

Afghan Transitional Administration, and Afghan Development Forum, 2003, Program Overview and Projects to be Implemented by the Administrative Reform and Civil Service Commission," (April). 


\section{Chapter V. Monetary and Exchange Rate Policy in a Post-Conflict ENVIRONMENT: SIMPLE RULES AND FLEXIBILITY ${ }^{85}$}

\section{The Starting Point}

163. At the end of 2001, Afghanistan's financial system had largely ceased to exist. The country had become almost entirely cash-based. Banks had essentially stopped functioning during the Taliban years and whatever financial infrastructure had survived the many years of conflict was in very poor condition. What remained was the informal Hawala system that people could use to change and transfer money. ${ }^{86}$ Confidence in the national currency, the Afghani, was low, as it had lost much of its value following years of high inflation. Moreover, the Afghan central bank, Da Afghanistan Bank (DAB), had little or no control over the issuance of currency. At least three versions of the national currency were circulating in the country. First, there was the official Afghani, which had been issued prior to the Taliban rule and which the Taliban had continued to issue from the remaining stocks in the vaults of the central bank. In addition, duplicates of the official banknotes had been put into circulation during the Taliban years by the then internationally recognized government in exile, which had ordered reruns of earlier issued series from the country's regular printer and had issued these in the northern parts of the country. By using the same serial numbers as used in earlier years, the government in exile ensured that the new notes could not be distinguished from those already in circulation. Furthermore, two warlords had issued their own counterfeit versions of the official currency. While these counterfeits were very similar to the official currency, they did have some distinguishing features and typically traded at a discount in the Kabul money markets. Reflecting the limited confidence in the national currency, foreign currencies were also widely used, including the U.S. dollar and the currencies of neighboring countries. Foreign currencies were used especially for larger transactions and as store of value.

164. Against this background, the new government that came to office in late 2001 faced a number of key questions in the area of monetary policy. To help facilitate recovery and economic growth, an adequate degree of financial stability would need to be established. The question was how best to achieve this as quickly as possible. One of the most important and pressing issues in this regard was whether to temporarily adopt a foreign currency as legal tender, or whether to introduce a new national currency. And under the latter option, which would take time to implement, a plan would need to be devised for the interim period prior to completion. Also, under the latter option the central bank would need to have a framework to conduct monetary policy. What would be the objectives and intermediate targets of monetary policy? Would it be better to fix the exchange rate, or to let it float? And in the absence of a

\footnotetext{
${ }^{85}$ Prepared by Ron van Rooden and Louis Dicks-Mireaux.

${ }^{86}$ See Chapter VI for a description of the state of the financial system in Afghanistan in 2001 and its development thereafter.
} 
functioning banking system, what instruments could be used to implement monetary policy? This chapter discusses these issues, the various options that were open to the authorities, and the choices they have made, as well as the actual conduct of monetary and exchange rate policy during the past $1 \frac{1}{2}$ years.

\section{The Choice OF CURRenCY}

165. It was clear that financial stability could not be achieved under the prevailing circumstances, with little or no control over the issuance of money. In addition, donors were looking for reasonable assurances that the effectiveness of their assistance would not be eroded by high inflation. Thus, one of the first critical economic issues facing the new government was the choice of currency that would serve as legal tender. From the outset, the authorities indicated their desire to introduce a new national currency as soon as possible. IMF staff, however, recommended that the introduction of a new currency be considered at a somewhat later stage, as it required time because of technical considerations (design, printing, etc.) and, more importantly, because of the need to establish sound and credible financial policies and an adequate institutional and legal framework to support the value of the new currency. Several options could be considered for the interim period leading up to the introduction of the new currency, ranging from adopting a stable foreign currency as legal tender to the continued use of the existing Afghani.

166. One possible option for the interim period was a full dollarization until the new Afghani could be successfully launched. The temporary use of a stable foreign currency would have provided immediate monetary stability, as well as time to establish credibility and to build up the necessary capacity at DAB. Full dollarization, however, would have entailed an upfront redemption of all existing Afghanis that would have required considerable organization. Moreover, this approach would have been expensive, requiring significant additional donor assistance. Also, full dollarization might have been potentially difficult to reverse.

167. An alternative option, recommended by IMF staff based on pragmatic economic and technical grounds, was to use a foreign currency to conduct government transactions until the new currency could be introduced. Meanwhile, the public would have been free to use any mutually agreed currency for any transaction and to hold any currency. Existing Afghanis would have continued to circulate until redemption by the new currency, within a floating exchange rate regime, but the central bank would not issue more Afghanis. The government would have announced its commitment to redeem existing Afghanis for the new currency at a later to be determined rate. The risk of counterfeits would have remained, but would have had less impact. This approach would have imposed a substantial degree of transparency and discipline on both fiscal and monetary policy, thus contributing to financial stability.

168. The authorities, however, decided to continue to use the existing Afghani and to introduce a new currency as soon as was technically possible. The authorities viewed the Afghani as an important symbol of sovereignty and unity, and were concerned that even a partial and temporary dollarization would be difficult to reverse. While the authorities 
recognized the risks posed by the various counterfeits to financial stability, they believed that these risks had diminished, based on information received from at least some of the printers involved regarding volumes printed, and their assurances that printing had stopped. Also, it was discovered that the Taliban, while in government, had started preparations for the introduction of a new currency and had signed a contract with a reputable banknote printer. Some work had already been done, including preliminary designs of various denominations. Because of the U.N. embargo, however, this agreement had been put on hold, but with the sanctions lifted, this allowed for a significant shortening of the technical lead-time needed to launch the new currency. As the value of the old Afghani had been eroded by inflation-the largest denomination (Af 10,000) was worth about $\$ 0.25$ and people had to carry around large bundles of cash for anything other than the smallest of transactions-one new Afghani would replace 1,000 old ones.

169. The introduction of the new currency was a crucial step in the authorities' efforts to establish financial stability and create an environment that is conducive to restoring sustainable economic growth in Afghanistan. The plan for the introduction of the new currency was made public on September 4, 2002 and the conversion process started on October 7, 2002. Replacing all banknotes in a post-conflict country such as Afghanistan within a fairly short period posed tremendous logistical challenges (details of the currency conversion are provided in Box V.1). Nevertheless, the authorities, assisted by the international community, managed to complete the changeover successfully on January 2 , 2003. Moreover, they managed to do so much earlier than many had thought possible and without any major incidents. There was no last minute rush or queues during the last days of the exchange period, nor were there any late shows after the closing of the exchange points. The exchange rate of the Afghani has remained broadly stable since the completion of the conversion process, reflecting not only sound financial policies, but also the population's confidence in the new currency.

\section{Preconditions for a Successful Monetary Policy}

170. The authorities' decision to introduce a new currency and to continue to use the existing Afghani in the interim created the need to rapidly develop capacity at the central bank to ensure that it would be able to conduct monetary policy. DAB's capacity to perform key central bank functions was extremely weak. The central bank was little more than an empty shell, with ample staff, but virtually none that had any knowledge of modern monetary policy and banking, no computers, no recent balance sheet, and little or no communication with its many branches in the provinces. The IMF and several other donors, notably USAID, assisted DAB in its efforts to quickly build adequate capacity.

171. The authorities decided that the primary objective of monetary policy should be to achieve and maintain price stability and, thus, to restore confidence in the (new) national currency. Furthermore, to ensure that monetary policy could be successful in achieving low inflation, the authorities recognized that the following three main preconditions would need to be met: 


\section{Box V.1. Introducing the New Currency}

1. The introduction of the new currency was a difficult task. Afghanistan is a rugged country slightly larger than France, with a population of about 22 million, that had been ravaged by over 20 years of armed conflict. Roads were in very poor condition, there was little or no secure ground transportation between major cities, and there was a lack of communication facilities. To reach all holders of the old currency within a limited period of time posed enormous logistical challenges. To address these vast challenges a steering committee was formed of senior officials from the central bank and the Ministry of Finance (MoF), assisted by international experts from the IMF, USAID, the Bundesbank, and the UN. Planning for the exchange started in earnest in the early summer of 2002 with the formation of a task force, composed mainly of senior officials from the central bank and several international advisors.

2. The first stages included the ordering, printing and delivery of the new bank notes. DAB contracted the printing of the new currency in denominations of Af 1, 2, 5, 10, 20, 50, 100, 500, and 1,000 to two reputable banknote printers, building upon the work that had already been done for the Taliban regime. The new notes included several advanced security features to deter future counterfeiting. It was difficult to determine how many new banknotes would be needed. The authorities only had a crude estimate of the existing amount of old notes in circulation. Including the various counterfeits, the face value of the old Afghanis in circulation was initially estimated at about Af 16 trillion. For political reasons, it was decided that two types of unofficial notes would be eligible for conversion, but at a 50 percent discount (close to the actual discount at which these counterfeits traded in the Kabul money market). Taking this discount into account, the total value of old Afghanis to be exchanged was estimated at about Af 13 trillion. The authorities realized, however, that running out of new bank notes before all old ones would be converted would fatally undermine the public's confidence in the new currency. Because of this, and to be able to accommodate an increase in money demand at least in the first year following the new currency's introduction, the authorities ordered a total value of the new notes of Af 27.9 billion (with 1 new Afghani replacing 1,000 old ones), equivalent to almost 800 million notes or about 500 tons. The first deliveries were received in August 2002 and the last shipments arrived in January 2003. The five smallest denominations make up almost 90 percent of the total volume of notes ordered, but only 15 percent of the total value (Figure 1).

3. A first problem to overcome was the extremely poor condition of DAB's regional facilities. DAB had 89 branches, but most of them did not meet even the most basic requirements in terms of secure vaults and office space. With the assistance from international donors, DAB urgently set out to refurbish or construct a minimum of one currency distribution facility in each province. The country was divided into seven regions, each the responsibility of an area manager. In addition to Kabul, the regions were Kunduz, Mazar-i-Sharif, Herat, Kandahar, Jalalabad, and Gardez. Each region had a number of exchange points, depending on estimates of population size and levels of economic activity. All in all, 47 exchange points were established where the public could exchange their old notes for new ones. An exchange point consisted of one to five units, with each unit having 7 windows: 5 windows to take in the old currency and 2 to give out the new currency. With communication still difficult, the success of the whole program depended significantly on the work of the area managers and exchange point managers, who often had to act on their own to deal with problems in their regions. Some 2,500 local staff were selected to carry out the operation. Staff was selected from the most experienced and skilled personnel in the banking sector. In order to motivate staff and to establish reliable operations, staff were paid considerably more than the $\$ 30$ to $\$ 40$ a month that a bank employee would normally earn. In addition, the UN and USAID provided international observers to oversee the process, notably the destruction of old notes.

4. Transportation was another obstacle to tackle. The 500 tons of new currency had to be delivered to exchange points throughout the country, with almost half of this to be transported to the provinces. Ground transport for the more distant locations was ruled out for security reasons. Air transport was seen as the best approach, but the facilities available were very limited. The bulk of the need for air transport was met by two helicopters and one airplane, an Antonov 32, provided by USAID. USAID also set up an air operations unit that handled the scheduling and coordination of flights (all flights required clearance from the regional military air command and a two-day advance notification). The Afghan Air Force also provided some assistance, particularly in the early stages of the conversion period, when difficulties in obtaining aircraft and crews that were willing to operate in Afghanistan led to delays in the arrival of the helicopters and the airplane. 


\section{Box V.1. Introducing the New Currency (continued)}

5. Adequate security was yet another requirement, with security needed at all stages, from the delivery of the new currency to the destruction of the old currency. The government, together with DAB, provided all the security during the currency conversion process. The governor and deputy governors of DAB visited the governors and local commanders in the provinces to ensure their cooperation. It is notable that there were no major security problems or serious violations of procedures during the entire three-month exchange period.

6. The introduction of the new currency was made public on September 4, 2002 by President Karzai. This was followed by a broad public information campaign to ensure that most if not all Afghans would be aware of the conversion. With large parts of the population illiterate and hardly anyone having a television, the campaign relied mainly on radio broadcasts and dissemination by word of mouth, through speeches, village meetings, etc. Also, a large number of posters were distributed, depicting the new notes and specifying their main security features. The conversion process started on October 7, 2002 and was initially set to last two months, ending December 4, 2002. The authorities opted for a relatively short changeover period to limit the risk of new counterfeit printing. A currency decree was issued to enable and to regulate the implementation of the currency conversion.

7. During the first two weeks of the exchange period, only the money changers would be allowed to exchange their old notes. This way DAB aimed to collect large volumes of old notes early on. In order to be able to handle the large volumes that were expected to be exchanged this way, a sampling procedure was agreed with the money changers, whereby only 10 percent of the total amount presented was verified to make sure that the count was correct, the denominations were correct, and the notes were indeed eligible for exchange. If the sample count found, for example, 2 percent to be incorrect, this proportion would be discounted from the entire amount that a money changer was presenting.

8. Demand from the general public to exchange their old bank notes was such, however, that the exchange was opened to the general public before the first two weeks were over. Thus, almost all of the exchange points in the major cities opened in the first two weeks. Many exchange points in the provinces had delays in opening, due in large part to delays in the arrival of air transport, but also because many were simply not yet operational until two to three weeks after their planned opening at October 21. In November, uncertainty grew among the general public whether everyone would be able to convert their old notes for new ones on time. As result, the exchange rate started to depreciate sharply. To ease these pressures, DAB announced in mid-November that the conversion period would be extended by one month to January 2, 2003. Following this announcement, the exchange rate quickly returned to levels close to those at the start of the exchange.

9. In the initial period, large denomination bank notes, 1,000, 500, 100, and 50 Afghanis, dominated the exchange, reflecting the early and active role of money changers. This also meant that the weight of bank notes, relative to their value, was much less than in the last month of the exchange, when primarily low denomination bank notes (1, 2, 5, and 10 Afghanis) were exchanged. Af 13.9 trillion worth of old official notes were exchanged during the conversion process for new notes, plus Af 3.3 trillion in unofficial notes at a 50 percent discount. Thus, Af 15.6 billion of new notes were issued in exchange. An additional Af 2 trillion in old official notes were absorbed through the foreign exchange auctions during the conversion period. All in all, some Af 19 trillion in old notes were collected, equivalent to some 5 billion banknotes or over 2,000 tons, almost 20 percent more than the estimated face value of banknotes based on the information received from the printing companies. This difference may reflect inaccurate or incomplete information received from the printers, "last minute" printing of counterfeits, or round-tripping of old notes during the currency conversion process. To address the problem of round-tripping, initially old bank notes were to be invalidated, using punchers and drills, and to be subsequently destroyed, using shredders. However, this approach quickly proved to be ineffective, as the arrival of equipment was delayed and, once it arrived, had a tendency to break down. The solution to the destruction problem was to use incineration as the principal method. Difficulties in transportation and security meant that the best approach was to incinerate the notes locally. The construction of ovens was relatively simple and inexpensive. Also, ovens did not require electricity, which was lacking in many exchange points. A schedule was established for the weekly or two-weekly destruction of the old bank notes, with the requirement that there be both international and national observers present to assure the integrity of the process. The exchange ended quietly on January 2, 2003. 


\section{Box V.1. Introducing the New Currency (concluded)}

Figure 1. Afghanistan: Currency Denominations, 2003 1/

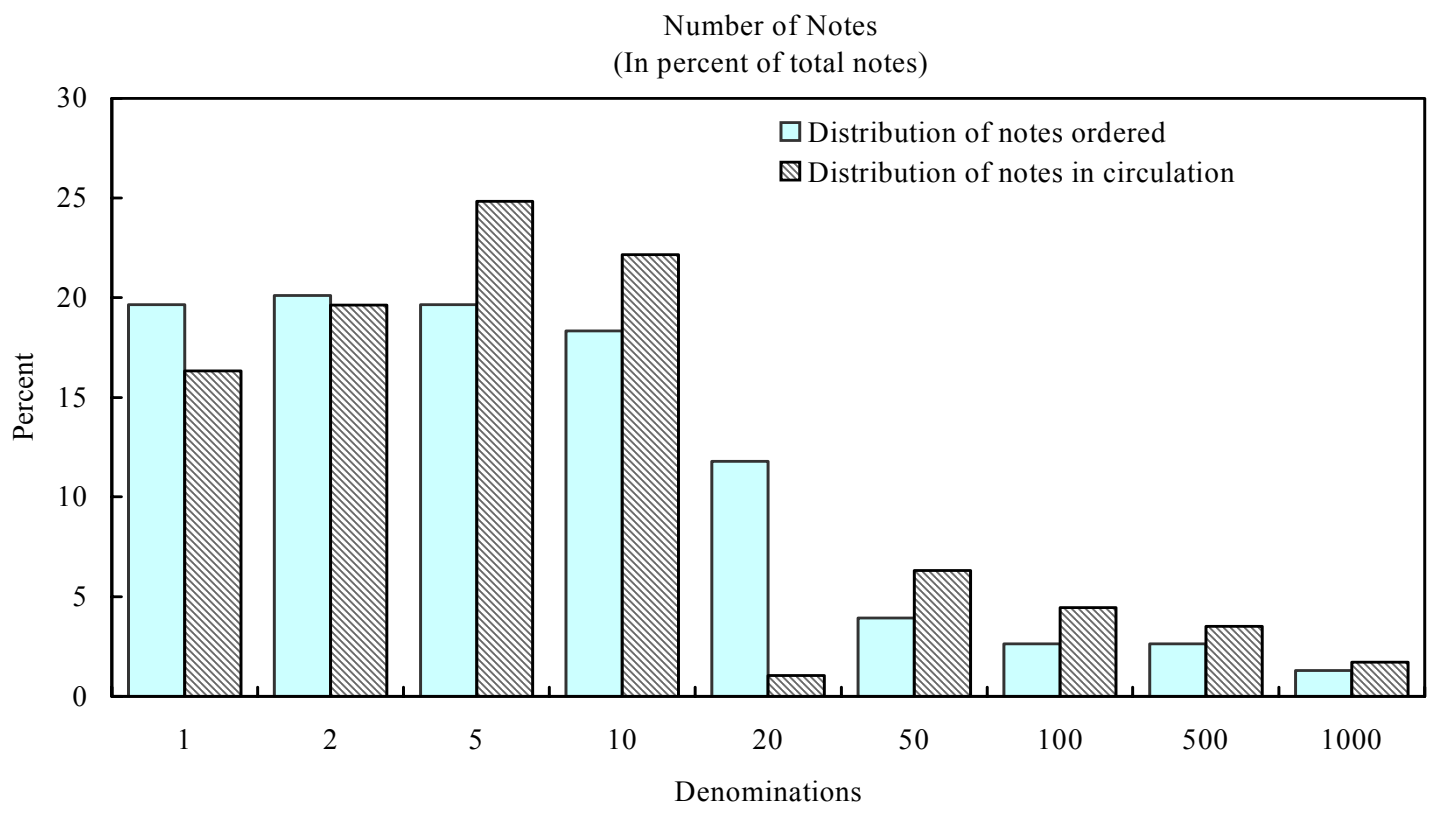

Value of Notes

(In percent of total value)

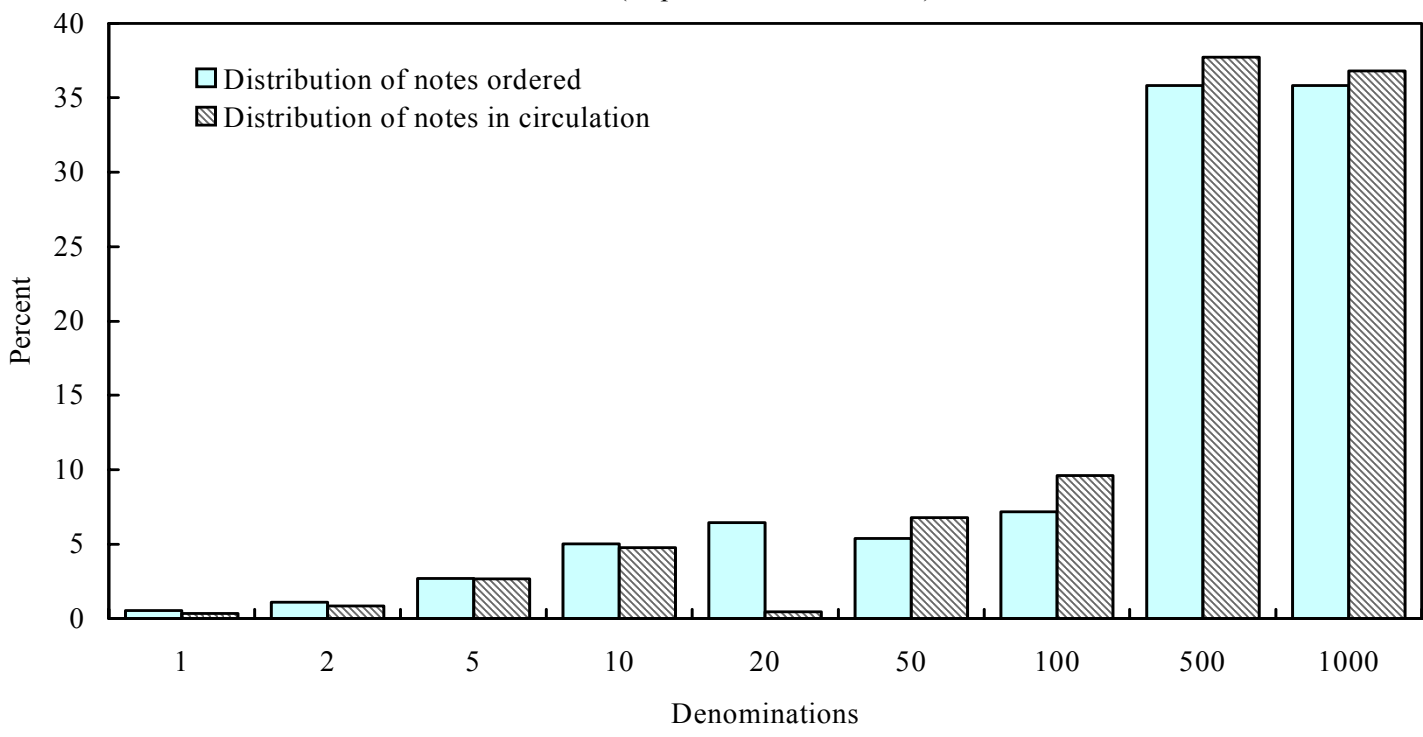

Source: Da Afghanistan Bank.

1/ Data reflect the situation per May 21, 2003. 
- $\quad$ DAB would need to have full jurisdiction and control over the printing, delivery, and issuance of the domestic currency. To achieve this, as noted, the authorities pressed ahead forcefully with the introduction of the new currency.

- $\quad$ DAB would need to be independent from any other authority in the pursuit of its objectives and the performance of its tasks. DAB should neither seek nor take instructions from any other authority. The authorities requested the IMF to assist in preparing new central bank and banking laws to this effect. Draft laws were discussed at a seminar held in Delhi in December 2002 and were submitted to the Cabinet in August 2003. A Cabinet committee is currently reviewing the laws and they are expected to be approved later this year. ${ }^{87}$

- $\quad$ The government would need to maintain strict fiscal discipline. In particular, DAB should refrain from financing the government budget, or any government agency or government-owned enterprise, to break with the previous practice of automatic and unlimited overdraft financing that had resulted in high inflation and a sizeable depreciation of the exchange rate. Adopting a simple and straightforward rule to this effect would signal an unambiguous commitment to fiscal discipline. Thus, the authorities included in the 2002/03 budget decree a provision that prohibited the government from taking recourse to central bank financing. This provision was repeated in the 2003/04 budget.

172. The next step was to define the appropriate framework for monetary policy. What would be the intermediate target for monetary policy? A first question in this regard was to determine the appropriate exchange rate regime for Afghanistan.

\section{Fixed OR FleXible: the Choice of The EXChange Rate Regime}

173. In choosing an exchange rate regime, a country has to trade off the advantages of more exchange rate stability against the advantages of more flexibility. Two big advantages of fixing the exchange rate for a country are: (a) to reduce transaction costs and exchange rate risk, which can discourage trade and investment; and (b) to provide a credible nominal anchor for monetary policy. The big advantage of a floating exchange rate regime, on the other hand, is the ability to pursue an independent monetary policy. Moreover, a floating regime enhances a country's ability to absorb (external and real) shocks. Several countries choose something in between rigid fixity and free-floating, although many argue that intermediate regimes are no longer tenable because of the increasing integration of financial markets. $^{88}$

\footnotetext{
${ }^{87}$ See Chapter VI for a discussion of these laws.

${ }^{88}$ See Frankel (1999).
} 
174. Afghanistan's economy has a number of characteristics that were relevant for choosing the appropriate exchange rate regime. The importance of each of these characteristics may change over time, however. Some of these characteristics favor a fixed regime, some favor flexibility. Characteristics suggesting that Afghanistan would benefit more from exchange rate stability than from monetary independence include:

- Afghanistan is a relatively small and open economy. Trade would obviously benefit from exchange rate stability.

- $\quad$ The openess of the economy is also reflected by the strong and rapid pass-through of exchange rate movements into consumer prices. Fixing the exchange rate could be a simple and straightforward way to stabilize prices.

- Afghanistan has a history of high and variable inflation, and the economy is highly dollarized. A fixed exchange rate would provide a clear nominal anchor for monetary policy. Acceptance and use of the new currency would be greater if its exchange rate were to remain fairly stable. If the exchange rate would continue to be highly volatile and the currency would again lose its value, dollarization could be expected to increase further.

- $\quad$ There is little or no economic data available to the public. A fixed exchange rate would provide an anchor not just for monetary policy, but for the economy in general. The exchange rate is one of the very few variables that can easily be observed by everyone.

- $\quad$ The capacity to implement economic policies, in particular at the central bank, was weak, favoring simple, fixed rules. A currency board, for example, would be simple to administer as it does not require a full-fledged central bank.

175. On the other hand, a number of other chararcteristics of the Afghan economy favored exchange rate flexibility:

- Afghanistan's economy is undergoing large structrual changes and the equilibrium exchange rate will change as a result. Thus, there would be a considerable risk of an exchange rate misalignment in a fixed regime. The reconstruction phase would likely be accompanied by large foreign exchange inflows, both from donors and repatriation of funds by Afghanis, which may cause the real exchange rate to appreciate. A more practical matter is that in present day Afghanistan, it would be very difficult to get a firm idea as to what the appropriate exchange rate level would be in a fixed regime, not in the least because of the lack of reliable data (see Box V.2).

- Afghanistan continues to be very vulnerable to shocks, both external and domestic, and both real and financial. These shocks include inter alia trade shocks, droughts, earthquakes, and political tensions. Under a fixed regime, labor and product markets would need to have a high degree of flexibility to absorb such shocks. While these markets can be expected to have considerable flexibility, the question would remain whether it would be desirable to let these markets absorb these shocks rather than to let the exchange rate adjust. 


\section{Box V.2. What is the Right Exchange Rate Level?}

1. Since the collapse of the Taliban regime there have been large changes in Afghanistan's economy, including its trading patterns. The exchange rate has meanwhile fluctuated widely. Is it possible to make a judgment about the appropriate "equilibrium" level of the exchange rate for the Afghani? The equilibrium real exchange rate (or nominal rate after adjusting for inflation differentials) would be the rate that would be consistent with a sustainable current account position, without the need for major changes in international reserves or shift in macroeconomic policies. ${ }^{1 /}$

2. Information typically used to assess the appropriateness of the exchange rate level is notably lacking for Afghanistan. There is no sensible base year against which to compare the current level of the real exchange rate. There have been huge changes in the pattern and composition of trade in the past 20 years and consequently a base year during this period would not be relevant to Afghanistan's current circumstances. Moreover, there is very little information available on indicators used to assess competitiveness such as growth rates of export and import volumes, the pattern of trade, relative price and wage costs vis-à-vis trading partners and competitor countries, and the level of foreign exchange reserves.

3. A few partial indicators of international competitiveness are available. Most of Afghanistan's own exports (that is, excluding reexports) are to India and Pakistan. These and other countries in the region are likely to be Afghanistan's competitors in its export markets (agriculture and light manufacturing). For imports, the major sources appear to be Pakistan, Korea, Japan, Iran, and, since 2002, the USA; for Iran and Pakistan available import data possibly include goods in transit from other countries. Most of the imports are likely to be goods (e.g. cars, refrigerators, and televisions) that Afghanistan does not produce. Imports from neighboring countries, however, are more likely to compete with domestic substitutes (e.g. agricultural goods and construction materials). As regards competitiveness, in Pakistan, Afghanistan's largest bilateral partner, civil servants in the lower grades are paid (including food and transport allowances) the equivalent of about \$38 a month compared with \$35 in Afghanistan. However, compared to Pakistan, data suggest that in Afghanistan wages for unskilled labor in the private sector are substantially higher; in early 2003, wages for unskilled labor paid by foreign companies and agencies typically are in the order of \$100 per month. A comparison of inflation rates and nominal exchange rate movements in 2001, 2002, and the first half of 2003, suggests that Afghanistan has become less competitive vis-à-vis most nearby countries in the region. This reflects the large appreciation of the Afghani against the U.S. dollar in late 2001 and a higher rate of inflation. In addition, productivity is probably higher in neighboring countries than in Afghanistan because the years of conflict resulted in low levels of investment and a destruction of much of its infrastructure. In the case of transit trade, the damage to roads has contributed to higher transport costs, slow traffic movement, and greater damage to goods.

4. Looking ahead, there may be a so-called "Dutch Disease" effect that could put upward pressure on the equilibrium real exchange rate. Official external financial assistance is expected to rise and remain at a high level relative to the size of Afghanistan's economy for at least the next few years, before settling to lower levels. The composition of aid is expected to shift from humanitarian aid, with a high import content, to infrastructure and project aid, with a lower import and higher domestic content, and a positive impact on the production capacity of the economy. There will also be a continued reflux of refugees which will contribute to increased domestic spending. The resulting increase in domestic spending on nontraded goods would lead to a rise in the relative price of nontraded to traded goods (the real exchange rate) and a shift of resources from the traded goods sector to the nontraded goods sector. However, there are also several factors that could offset these effects. The economy is operating at a low level and given the existing underutilization of capacity, including labor and the return of refugees, domestic production could rise rapidly in response to increased demand and reduce upward pressures on the price of nontraded goods. Also, as the reconstruction effort moves forward, supply bottlenecks could be eased, productivity could rise, and some costs decline (for example, transportation), all of which would dampen increases in domestic prices and loss of competitiveness. Moreover, given the large share of transit trade in Afghanistan's trade, a decline in transshipment costs would significantly improve the attractiveness of Afghanistan as a transit route.

$1 /$ The real exchange rate can be defined as: $\mathrm{RER}=\mathrm{ePD} / \mathrm{PF}$, where $\mathrm{PD}$ is the domestic price level, $\mathrm{PF}$ the level of foreign prices, and $\mathrm{e}$ is the nominal exchange rate (measured in units of foreign currency per unit of domestic currency). The prices used are typically those of imports and exports, or tradable and nontradable goods. 
- The authorities had yet to establish credibility. In the eyes of economic agents, the government had at best no track record in terms of economic policies or at worst a poor track record of high inflation. A firmly fixed rate, such as in a currency board arrangement, could help to establish credibility, but a currency board would not offer "credibility in a bottle." In particular, the authorities' commitment to fiscal discipline had not yet been put fully to the test.

- $\quad$ There was no obvious anchor currency. The choice of the right reference currency is an important one. In the case of Afghanistan, a question would remain to which foreign currency the domestic currency should be pegged. The U.S. dollar or the currency of one of the neighbouring countries? Only limited information is available regarding the composition and direction of trade, but it appears that a large share of Afghanistan's trade is with neighbouring countries. But at the same time, a signifcant share of trade flows seem to be denominated in U.S. dollars. Fixing the rate against the U.S. dollar could result in a real appreciation against neighbouring countries, adversely affecting Afghanistan's competitiveness. On the other hand, fixing the rate against the currencies of neighbouring countries could adversely affect stability.

176. The Afghan authorities decided that despite the advantages of a fixed type regime such as a currency board, on balance Afghanistan's existing economic conditions favored a floating exchange rate regime, at least for the near term. The risks associated with a fixed peg or currency board arrangement are currently too large. Trying to defend an unsustainable exchange rate would run the risk of quickly depleting the country's foreign exchange reserves. However, once the economy has moved beyond the early structural changes inherent to the reconstruction process, the choice of exchange rate regime could be revisited.

177. The authorities nonetheless see benefits in at least some degree of exchange rate stability. In particular, a relative degree of exchange rate stability is considered important to instill confidence in the new currency and to support price stability. Therefore, since the introduction and float of the new currency in early 2003, DAB has aimed to limit exchange rate volatility and to keep the exchange rate within a range. This range, however, is not firmly set nor announced and DAB does not intend to resist persistent exchange rate pressures should these emerge, and thereby risk losing its reserves. The exchange rate regime can therefore be described more accurately as a de facto (lightly) managed float, that is, more of an intermediate regime somewhere in between a pure float and a firmly fixed rate. The low degree of financial integration and market development allows DAB to pursue this approach, although the informal financial markets are such that people can quickly substitute one currency for another if they wish to do so.

\section{Formulating a Monetary Program}

178. Within the context of Afghanistan's floating exchange rate regime, IMF staff assisted $\mathrm{DAB}$ in developing an indicative quantified monetary program, aimed at achieving low inflation. The program aims to control the domestic money supply as an intermediate target. The ability to target inflation through the domestic currency supply is complicated, however, 
by the widespread use of foreign currencies. Inflation is likely to be influenced by changes in the stock of foreign currency holdings as well as the supply of Afghanis. The effects of changes in the stock of foreign currency holdings on inflation (and the exchange rate) depend in part on what the foreign exchange is used for (savings or daily transactions). However, there is little or no information on the size of foreign currency holdings in Afghanistan and their use.

179. In the absence of a functioning banking system, the domestic money supply is limited to the stock of domestic currency in circulation. Also, without any new central bank financing of the government, changes in the amount of currency in circulation are primarily driven by changes in DAB's (net) foreign asset position. In practice, this largely reflects the government converting the donor assistance it receives to finance the budget at DAB into Afghani, thereby increasing DAB's foreign assets. Without any action from DAB and given the size of budgetary assistance, these foreign exchange inflows would imply a doubling or more of the domestic money supply within one year, which would undoubtedly result in a renewed erosion of the value of the Afghani. To prevent this, an instrument to sterilize the monetary expansion was needed. However, without a functioning banking system or money market, the only market-based instrument that could be developed quickly was selling foreign exchange through foreign exchange auctions. IMF staff provided extensive assistance to DAB to establish and improve these auctions (see Box V.3), with the (larger) informal money traders acting as participants in these auctions.

180. The formulation of a monetary program for Afghanistan was complicated by the substantial uncertainties that surround the country's overall economic prospects and economic relationships. Inflation could be affected by factors beyond the central bank's control, including supply shocks, fluctuations in the international prices of imports, and political events. Given these large uncertainties, the monetary program needed to be based on cautious assumptions regarding the strength of the economic recovery and the demand for the domestic currency. In addition, it was clear that the target should not be pursued too rigidly, but that DAB would need to monitor developments closely and, if necessary, adjust the monetary program when needed to remain consistent with its inflation objective. In this regard, movements in the exchange rate, which is the only economic indicator that is readily available, can provide an early signal of changes in the relative demand for the domestic currency that may warrant a tightening or loosening of monetary policy.

181. A further, more practical, complication in formulating a monetary program was the lack of reliable data (at least prior to the introduction of the new currency) for the stock of Afghanis in circulation and, more generally, the absence of a balance sheet for the central bank. Estimates of the outstanding stock of Afghanis were based on information obtained from the banknote printer that had printed the official Afghani and one other printer that had printed one of the counterfeit versions. By combining the estimate of the amount of currency in circulation with estimates of DAB's foreign assets that had so far been identified, plus an estimate of the government overdrafts that had been accumulated over the years and for which some records were found, a very crude estimate of DAB's balance sheet could be put 


\section{Box V.3. Foreign Exchange Auctions}

1. With IMF staff assistance, DAB quickly established foreign exchange auctions, with auctions starting in May, 2002. Auctions are open to all licensed money changers. Initially, only the larger money changers participated, but as money changers became more familiar with the auctions, the number of participants soon increased from about 10-20 in May-June, 2002 to 30-60 after July, 2002. In the first half of 2003, the number of participants was usually in the range of 50-80, with a few money changers in the provinces also participating. DAB has progressively taken measures to improve the transparency and operation of the auctions. These measures have included public announcements of the auctions in advance in local newspapers and on radio, the announcement of successful bids at the auction in the presence of the participants, and a clear explanation of auction procedures and any changes to be introduced at the outset of auctions. The mechanics of the auctions have also become more efficient and systematically applied. For example, on several occasions, money changers who had made successful bids did not settle. To discourage this behavior, DAB began prohibiting participation in the auctions on a temporary basis for these money changers and repeated offenses would result in a permanent ban on participation ("three strikes and you are out"). Subsequently, in April, 2003, those wishing to participate in auctions were required to make in advance a (non-interest bearing) Afghani cash deposit equivalent to $\$ 10,000$ with DAB. Failure to settle a successful bid would risk forfeiture of the deposit. This requirement and forfeiture is being formalized in a cash collateral agreement between DAB and participants, and is expected to be approved later in 2003. Also, DAB is reviewing draft rules and regulations for the auctions which are expected to be issued later in 2003.

2. The modalities of the auction have been adjusted over time. Since November 2002, the sealed advance bids have been used as the starting point by the auctioneer (the governor or deputy governor of DAB) to offer a sell price for U.S. dollars to participants in an auction session to which all bidders are invited. The auction closes when the auctioneer and participants agree on a mutually acceptable single clearing exchange rate. The auctioneer, however reserves the right not to sell. The amounts of U.S. dollars requested in the sealed bids of the participants who finally agree to buy U.S. dollars at the agreed exchange rate usually exceed the amount on offer. Therefore, and also to avoid any cornering of the market, broadly equal amounts of U.S. dollars are awarded to each successful bidder, with the highest bidder receiving a larger amount.

3. The amounts auctioned are linked to the overall monetary program. Auctions have for much of the time been held on a fairly regular basis at $1-2$ week intervals. By the end of the first quarter of 2003/04, 50 auctions had been held. The amounts sold per auction were on average about $\$ 2$ million for the first six months and since then have usually been in the range of \$5-10 million. The amounts and timing of the auctions have reflected the rate of monetary expansion, driven by the pace of government spending, and the size of movements in the exchange rate. In 2002/03, a total of $\$ 135.4$ million (Af 6.2 billion) was sold through the auctions and in the first quarter of 2003/04, $\$ 34.5$ million (Af 1.7 billion) was sold.

together (Table V.1). This estimate was used as a basis for the monetary program. The program was updated regularly as new information became available, particularly following the completion of the currency conversion when the stock of currency in circulation could finally be determined accurately. 
Table V.1. Afghanistan: Monetary Developments (Da Afghanistan Bank), 2001-04

\begin{tabular}{|c|c|c|c|c|c|c|c|c|c|c|}
\hline & \multirow{2}{*}{\multicolumn{2}{|c|}{$\begin{array}{c}2001 / 02 \\
\text { Est. }\end{array}$}} & \multicolumn{5}{|c|}{$2002 / 03$} & \multicolumn{3}{|c|}{ 2003/04 } \\
\hline & & & \multicolumn{5}{|c|}{ Est. } & \multicolumn{3}{|c|}{ Est. } \\
\hline & Dec. 21 & Mar. 20 & Jun. 21 & Sep. 22 & Sep. 22 & Dec. 21 & Mar. 20 & Jun. 21 & Jul. 22 & $\overline{\text { Aug. } 22}$ \\
\hline & \multicolumn{10}{|c|}{ (In millions of new Afghani, unless indicated otherwise) } \\
\hline Net foreign assets $1 /$ & $\ldots$ & 10,727 & 12,567 & 12,436 & $\ldots$ & 17,951 & 19,602 & 24,031 & 24,684 & 25,558 \\
\hline Foreign exchange reserves $2 / 3 /$ & $\ldots$ & 11,053 & 12,893 & 12,762 & $\ldots$ & 18,392 & 19,602 & 24,031 & 24,684 & 25,558 \\
\hline Gold & $\ldots$ & 6,674 & 6,674 & 6,674 & $\ldots$ & 9,030 & 9,030 & 9,030 & 9,030 & 9,030 \\
\hline Other & $\ldots$ & 4,379 & 6,219 & 6,087 & $\ldots$ & 9,362 & 10,572 & 15,001 & 15,654 & 16,528 \\
\hline Foreign liabilities & $\ldots$ & -326 & -326 & -326 & $\ldots$ & -441 & 0 & 0 & 0 & 0 \\
\hline Net domestic assets & $\ldots$ & 3,041 & 2,038 & 2,268 & $\ldots$ & 1,196 & 1,074 & $-3,691$ & $-3,077$ & $-3,206$ \\
\hline Domestic assets & $\ldots$ & 14,525 & 14,857 & 14,376 & $\ldots$ & 15,084 & 14,450 & 10,541 & 11,370 & 12,139 \\
\hline Net claims on general government & 14,577 & 14,525 & 14,857 & 14,376 & $\ldots$ & 15,084 & 14,450 & 10,541 & 11,370 & 12,139 \\
\hline Net claims on government before 2002/03 (SY 1381) 4/ 5/ & 14,577 & 14,525 & 14,951 & 14,951 & $\ldots$ & 14,951 & 14,951 & 14,951 & 14,951 & 14,951 \\
\hline Net claims on government in 2002/04 (SY 1381/1382) 5/ 6/ & 0 & 0 & -93 & -574 & $\ldots$ & 133 & -501 & $-4,410$ & $-3,581$ & $-2,811$ \\
\hline Domestic currency deposits 5/ & 0 & 0 & 410 & -87 & $\ldots$ & 887 & -344 & -975 & -327 & -458 \\
\hline Foreign currency deposits 6/ & 0 & 0 & -503 & -487 & $\ldots$ & -754 & -157 & $-3,435$ & $-3,254$ & $-2,353$ \\
\hline Claims on nonbank public institutions & $\ldots$ & 0 & 0 & 0 & $\ldots$ & 0 & 0 & 0 & 0 & 0 \\
\hline Claims on deposit money banks & $\ldots$ & 0 & 0 & 0 & $\ldots$ & 0 & 0 & 0 & 0 & 0 \\
\hline Other items net $3 /$ & $\ldots$ & $-11,483$ & $-12,819$ & $-12,108$ & $\ldots$ & $-13,888$ & $-13,376$ & $-14,232$ & $-14,447$ & $-15,346$ \\
\hline Reserve money & 13,475 & 13,769 & 14,606 & 14,704 & 18,384 & 19,146 & 20,676 & 20,340 & 21,606 & 22,352 \\
\hline Afghanis in circulation $7 /$ & 13,475 & 13,769 & 14,606 & 14,704 & 18,384 & 19,146 & 20,676 & 20,340 & 21,606 & 22,352 \\
\hline Banknotes and coins issued & 13,509 & 13,809 & 14,718 & 14,718 & $\ldots$ & 19,831 & 21,302 & 21,302 & 22,302 & 23,302 \\
\hline less cash holdings & 34 & 40 & 112 & 14 & $\ldots$ & 684 & 626 & 962 & 696 & 950 \\
\hline Bank reserves & 0 & 0 & 0 & 0 & 0 & 0 & 0 & 0 & 0 & 0 \\
\hline Memorandum items: & \multicolumn{10}{|c|}{ (In percent, unless indicated otherwise) } \\
\hline Reserve money growth (quarterly) & $\ldots$ & 2.2 & 6.1 & 0.7 & $\ldots$ & 4.1 & 8.0 & -1.6 & $\ldots$ & \\
\hline Reserve money growth (annual) 8/ & $\ldots$ & & & $\ldots$ & $\ldots$ & & 20.1 & & & \\
\hline Gross international reserves (millions of U.S. dollars) & & 325.1 & 379.2 & 375.3 & $\ldots$ & 399.8 & 426.1 & 522.4 & 536.6 & 555.6 \\
\hline Inflation (quarterly; Kabul) & -36.8 & 25.2 & 1.6 & 18.3 & $\ldots$ & 31.9 & -4.0 & 2.0 & & \\
\hline Inflation (12-month; Kabul) & $\ldots$ & -43.4 & -35.3 & -4.9 & $\ldots$ & 98.5 & 52.3 & 52.9 & 41.7 & 51.4 \\
\hline
\end{tabular}

Sources: All figures are IMF staff estimates based on available data in Da Afghanistan Bank and the Central Statistics Office.

1/ Foreign currency amounts converted into Afghani at an exchange rate of Af $34=\$ 1$ until September 2002; thereafter at a rate of Af $46=\$ 1$; gold valued at $\$ 279$ per ounce. 2/ Increases reflect (net) flows plus recovered accounts abroad.

3/ In Q3 2002/03 (SY 1381), includes payment by DAB of \$16 million in costs for the new currency.

4/ Changes in Q1 2002/03 (SY 1381) reflect expenditures made and revenues booked for the 2001/02 (SY 1380) budget.

5/ Accounts 600100, 701101, and 731001 corrected for reallocation of 2002/03 (SY 1381) revenues to 2001/02 (SY 1380) for funding of 2001/02 (SY 1380) wage expenditures. 6/ Including disbursed AIAF, ARTF, and LOTFA funds (accounts 701102 and 731002).

7/ September 22, 2002 stock of currency in circulation calculated as January 21, 2003 stock of new Afghani in circulation minus net issuance of new Afghani during October 7, 2002-January 21, 2003 plus net withdrawal of old Afghanis (devided by 1,000) during during September 23, 2002-January 21, 2003.

8/ Annual percentage increase in 2002/03 (SY 1381) calculated by multiplying quarterly percentage changes 
182. A first indicative monetary program was formulated in April 2002 for the year 2002/03. The program targeted a 12-month inflation rate of somewhat below 20 percent by March 2003. Assuming economic growth in the order of 10 percent and a modest strengthening of money demand, the monetary program for 2002/03 aimed to limit money growth to less than 30 percent. A similar program was formulated in early 2003 for 2003/04, with only slightly different parameters. The 2003/04 program targets a 12-month inflation rate of about 15 percent by March 2004.

\section{Monetary AND EXCHANGE RATE DEVELOPMENTS IN 2002-03}

183. Monetary developments in 2002 and 2003 suggest that a fairly close relationship exists between domestic money growth, exchange rate movements, and the rate of inflation. Developments, particularly in 2002, also show that the exchange rate is very susceptible to rumors and (political) uncertainty and, furthermore, that the pass-through of exchange rate movements into prices is very strong and almost immediate.

184. Overall during 2002/03, currency in circulation grew by an estimated 20 percent, significantly less than the almost 30 percent originally targeted in the original monetary program (in the fall of 2002, the target was reduced to 24 percent). ${ }^{89}$ The rate of monetary expansion varied widely from quarter to quarter, reflecting both the volatility of money demand, as well as more practical constraints, such as the availability of sufficient volumes of the old banknotes prior to the introduction of the new currency. The increase in money demand during the year was entirely met by an accumulation of foreign reserves at the central bank; the government adhered to the no-overdraft rule and ended the fiscal year with a surplus. ${ }^{90}$ DAB's reserves increased by an estimated $\$ 100$ million in $2002 / 03$. During the year, DAB received foreign exchange inflows to help finance the government budget in the amount of $\$ 215$ million. DAB auctioned off $\$ 135$ million of this to limit monetary expansion. DAB also paid over $\$ 16$ million from its reserves to cover the cost of printing the new currency. In addition, a part of the increase in reserves reflects new information on foreign deposits that became available during the year, rather than an actual inflow of foreign exchange. At the end of 2002/03, DAB's stock of foreign exchange reserves was estimated at $\$ 426$ million. ${ }^{91}$ This level of reserves would appear to be adequate in the context of the current exchange rate regime to cushion the short-term impact of negative shocks, as well as to provide a strong backing for the national currency (see Box V.4).

\footnotetext{
${ }^{89}$ Due to the break in series because of the introduction of the new currency, the annual growth rate is calculated by multiplying estimated quarterly growth rates.

${ }^{90}$ The government occasionally ran an overdraft in the third quarter of 2002/03 and was still in overdraft by the end of the quarter. These overdrafts remained fairly limited in size, however. To some extent, the occurrence of these overdrafts reflected the procedure by which the government received foreign assistance only after expenditures have been made and their eligibility to be covered by such assistance has been established. But it also reflected a lack of adequate monitoring and communication between DAB and the MoF. An increase in available foreign financing for the budget allowed for the overdraft to be eliminated in the fourth quarter of 2002/03.

91 Including \$196 million of gold valued at \$279 per ounce.
} 


\section{Box V.4. Considerations on the Level of Foreign Exchange Reserves}

1. The level of external reserves held at the beginning of 2002 by DAB was uncertain. The only identified assets were those held (frozen) with the Federal Reserve Bank of New York and a few other banks, which amounted to about \$250 million (including \$196 million in gold). Since then the level of identified reserves has steadily increased as more assets have been located, primarily at banks in Europe, and because of inflows of donor funds to finance the budget. As of end-August 2003, DAB's foreign exchange reserves were estimated at $\$ 556$ million (\$600 million with gold valued at market prices). DAB is continuing to contact foreign banks to clarify the size and status of its foreign assets. As a more reliable estimate of DAB's reserves emerged and the authorities established a framework for macroeconomic and exchange rate policy, the question of what would be an adequate level of external reserves needed to be addressed.

2. Criteria to assess the adequacy of reserves can generally be related to the trade account or the capital account of the balance of payments. It should be recognized that, when applying any criteria, the adequacy of reserves is a dynamic concept: as the circumstances of a country change over time, so will the desirable amount of reserves. For the moment, Afghanistan has little or no access to international capital markets and thus would have to rely more on its own resources (reserves) than on international borrowing to smooth adjustments to shocks. The potential for such shocks in Afghanistan is large and is thus a key factor in determining reserve goals. Donor assistance, either in the form of lending or grants, could be available, but access to these would be at the discretion of the donor and may not be available quickly enough to offset the immediate impact of a shock.

3. When using a trade-based measure one looks at how many months of imports a country can finance with its reserves. Conversely, it shows how rapidly a country (or its exchange rate) might need to adjust to an (external) shock. Three months of imports coverage is often used as a rule of thumb to assess reserve adequacy. Reserves are generally considered low if they cover less than three months of imports. As noted in Chapter II, the availability of reliable trade data is limited for Afghanistan. But based on those data and estimates available, the stock of reserves held by DAB at end-August 2003 is estimated to cover some 3 months of imports (excluding reexports, imports exempt from duties which are largely externally financed, for example, by donors, and smuggled goods). Thus, the level of reserves could be considered to be just sufficient, although a higher level of reserves would, as noted, be warranted given the country's vulnerability to various shocks and its limited access to capital markets to provide a crucial cushion. Also, the recovery and reconstruction of the economy can be expected to generate a rapidly rising level of own imports, which is already occurring, and thus a higher level of desired reserves. The resumption of debt service payments would also have a bearing on the adequacy of reserves.

4. A capital account-based measure captures the potential for capital flight by residents. Typically, such a measure relates the level of reserves to relevant monetary aggregates (often the monetary base) and is relevant especially for countries with a (quasi) pegged exchange rate, weak banking systems, and an unstable money demand or a history of high inflation. Afghanistan has a history of high inflation that resulted in low confidence in the Afghani and the widespread use of foreign currencies. While confidence in the national currency has improved with the introduction of the new currency, the potential for large shifts between the Afghani and foreign currencies still exists and points to using a monetary aggregate-based measure in assessing the adequacy of reserves. In the absence of a functioning banking system, the relevant monetary aggregate is the stock of domestic currency in circulation; as and when the banking sector is reestablished, the relevant monetary aggregate could be expanded to include bank deposits in domestic currency. In August 2003, currency in circulation amounted to Af22.4 billion, equivalent to $\$ 456$ million at the prevailing exchange rate. This measure suggests that Afghanistan's level of foreign exchange reserves was more than adequate. Again, with economic growth resuming and confidence in the national currency strengthening, money demand can be expected to increase, requiring additional reserves. But as long as the government refrains from central bank financing of the budget, there is limited use of a central bank rediscount window by commercial banks, any increase in the demand for the domestic currency should be met by an inflow of foreign exchange reserves.

185. Monetary developments in $2002 / 03$ show that money demand in Afghanistan is indeed very difficult to predict. Very crude estimates suggest that the economy grew in real terms by almost 30 percent in 2002/03, while the overall price level, measured year-on-year, increased by 5 percent. This implies that money demand may have actually weakened in relation to nominal GDP in 2002/03, instead of strengthening as had been assumed when formulating the program. This underscores the large uncertainties surrounding even the most 
basic economic relationships in a post-conflict situation, the poor quality of data, and, more importantly, the need to make cautious assumptions, to remain pragmatic and to make adjustments as one goes along, taking into account all available information.

186. The exchange rate of the Afghani had strengthened dramatically in late 2001, during the collapse of the Taliban regime, appreciating from (old) Af 70,000-80,000 per U.S. dollar to about Af 25,000 per U.S. dollar in early 2002 (Figure V.1 and Table V.2). The exchange rate depreciated slowly in line with inflation to about Af 40,000 per U.S. dollar in August 2002. In the late summer and early fall of 2002, however, uncertainty about the introduction of the new currency and logistical problems during the first weeks of the conversion period caused the exchange rate to fall to over Af 70,000 per U.S. dollar in early November. People had become increasingly nervous about whether they would be able to convert their old notes into new ones in time; initially, the changeover period was planned to last a period of only eight weeks. DAB had also temporarily suspended its foreign exchange auctions after the start of the exchange because it lacked qualified staff to handle both operations at the same time. The sharp depreciation of the Afghani was passed through quickly to local prices, which increased by a cumulative 60 percent during September-November 2002. To ease the exchange rate pressures, DAB resumed foreign exchange auctions in mid-November and announced an extension of the banknote exchange period until January 2, 2003. The Afghani immediately strengthened and eventually stabilized at about (new) Af 46 per U.S. dollar in January. With the strengthening of the Afghani consumer prices came down as well, although somewhat less than the appreciation of the Afghani.

187. With the completion of the currency conversion in January 2003, DAB achieved full control over the printing and issuance of the national currency and it was now able to determine accurately the amount of currency in circulation. ${ }^{92}$ Since the beginning of 2003 , monetary policy has again been restrained, although the rate of monetary expansion continued to show large swings from quarter to quarter. On balance, however, currency in circulation grew by 17 percent in the first eight months of the year, slightly less than the 20 percent increase envisaged for that same period under the indicative monetary program. Money demand continued to be met by an accumulation of foreign exchange reserves in $\mathrm{DAB}$, which reached $\$ 555$ million by late-August, as the government continued to adhere to the no-overdraft rule in 2003. As a result of these sound monetary (and fiscal) policies, consumer prices have been broadly stable in 2003, with an average monthly rate of inflation of minus 0.1 percent during the first eight months. Moreover, in the absence of any major shocks, exchange rate stability was established with the exchange rate fluctuating around Af 48 per U.S. dollar. As such, DAB - and the authorities in general - have made remarkable progress in achieving financial stability.

\footnotetext{
${ }^{92}$ The amount of currency in circulation could be calculated simply as the amount of currency delivered by the printer, less the amounts remaining in DAB's vaults. But little or no information was available on a timely basis on amounts held in the vaults of DAB's branches. Until adequate communications have been established with the branches, currency that may be held there must be assumed to be in circulation.
} 
Figure V.1. Afghanistan: Exchange Rates, 1999-2003 1/
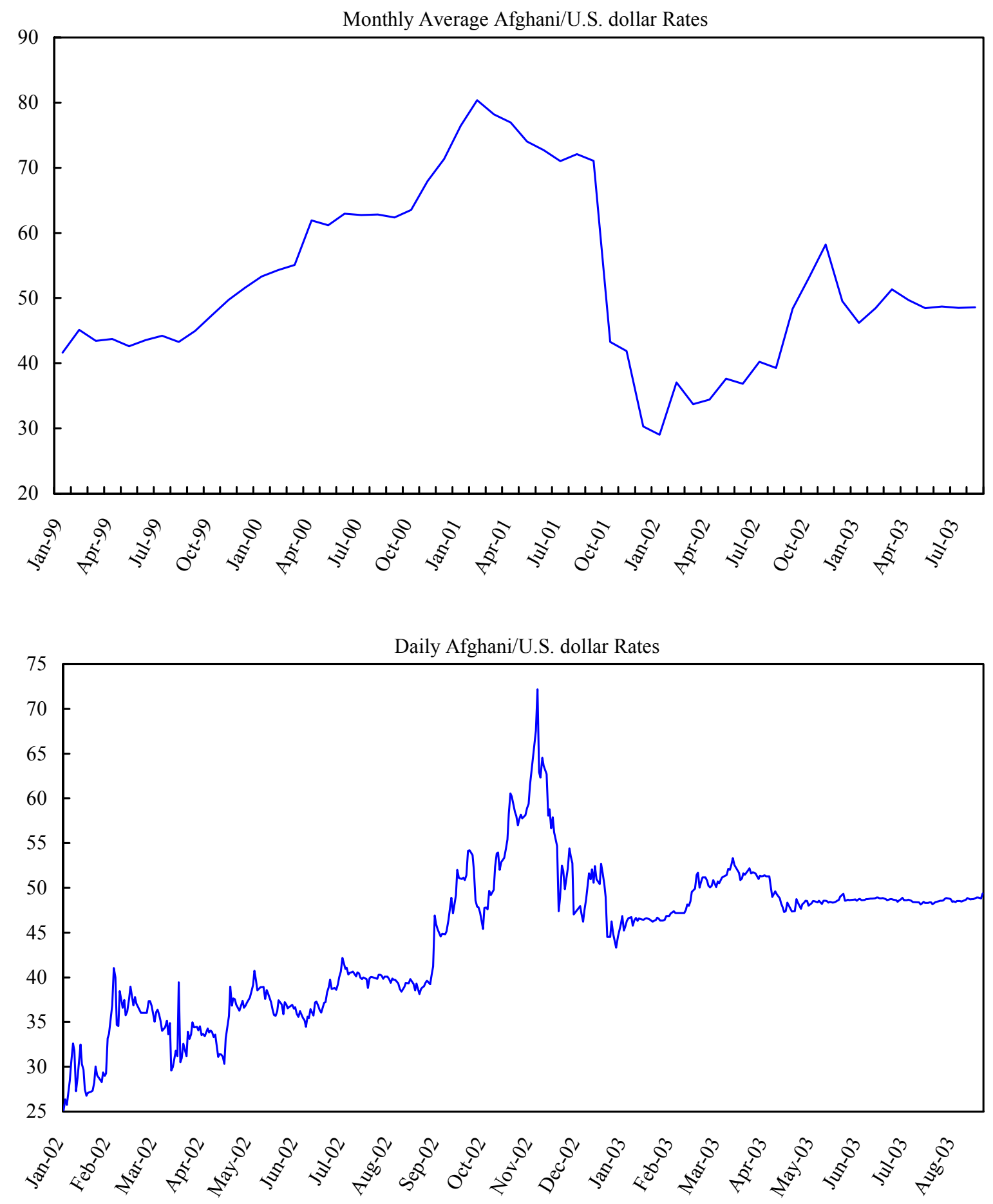

Source: Da Afghanistan Bank.

1/ In new Afghanis; last observation: August 31, 2003. 
Table V.2. Afganistan: Afghani/U.S. Dollar Exchange Rates (Cash), 1999-2003

\begin{tabular}{|c|c|c|c|c|c|c|}
\hline & & \multicolumn{3}{|c|}{ Monthly average } & \multirow{2}{*}{$\begin{array}{l}\text { Quarterly } \\
\text { average }\end{array}$} & \multirow{2}{*}{$\begin{array}{l}\text { Annual } \\
\text { average }\end{array}$} \\
\hline & & $\begin{array}{c}\text { Buying } \\
\text { rate }\end{array}$ & $\begin{array}{l}\text { Selling } \\
\text { rate }\end{array}$ & Average & & \\
\hline \multirow[t]{12}{*}{1999} & January & 41.56 & 41.68 & 41.62 & $\ldots$ & $\ldots$ \\
\hline & February & 45.09 & 45.20 & 45.14 & $\ldots$ & $\ldots$ \\
\hline & March & 43.41 & 43.50 & 43.45 & 43.41 & $\ldots$ \\
\hline & April & 43.67 & 43.78 & 43.73 & $\ldots$ & $\ldots$ \\
\hline & May & 42.57 & 42.68 & 42.62 & $\ldots$ & $\ldots$ \\
\hline & June & 43.49 & 43.60 & 43.55 & 43.30 & $\ldots$ \\
\hline & July & 44.17 & 44.28 & 44.23 & $\ldots$ & $\ldots$ \\
\hline & August & 43.23 & 43.34 & 43.28 & $\ldots$ & $\ldots$ \\
\hline & September & 44.92 & 45.03 & 44.98 & 44.16 & $\ldots$ \\
\hline & October & 47.28 & 47.39 & 47.33 & $\ldots$ & $\ldots$ \\
\hline & November & 49.70 & 49.82 & 49.76 & $\ldots$ & $\ldots$ \\
\hline & December & 51.53 & 51.64 & 51.58 & 49.56 & 45.11 \\
\hline \multirow[t]{12}{*}{2000} & January & 53.25 & 53.36 & 53.31 & $\ldots$ & $\ldots$ \\
\hline & February & 54.24 & 54.34 & 54.29 & $\ldots$ & $\ldots$ \\
\hline & March & 55.04 & 55.14 & 55.09 & 54.23 & $\ldots$ \\
\hline & April & 61.86 & 61.99 & 61.93 & $\ldots$ & $\ldots$ \\
\hline & May & 61.10 & 61.21 & 61.16 & $\ldots$ & $\ldots$ \\
\hline & June & 62.92 & 63.02 & 62.97 & 62.02 & $\ldots$ \\
\hline & July & 62.45 & 63.05 & 62.75 & $\ldots$ & $\ldots$ \\
\hline & August & 62.75 & 62.86 & 62.81 & $\ldots$ & $\ldots$ \\
\hline & September & 62.35 & 62.46 & 62.41 & 62.65 & $\ldots$ \\
\hline & October & 63.48 & 63.59 & 63.53 & $\ldots$ & $\ldots$ \\
\hline & November & 67.88 & 68.00 & 67.94 & $\ldots$ & $\ldots$ \\
\hline & December & 71.30 & 71.45 & 71.38 & 67.62 & 61.63 \\
\hline \multirow[t]{12}{*}{2001} & January & 76.38 & 76.51 & 76.44 & $\ldots$ & $\ldots$ \\
\hline & February & 80.32 & 80.45 & 80.39 & $\ldots$ & $\ldots$ \\
\hline & March & 78.05 & 78.26 & 78.15 & 78.33 & $\ldots$ \\
\hline & April & 76.89 & 77.01 & 76.95 & $\ldots$ & $\ldots$ \\
\hline & May & 73.98 & 74.10 & 74.04 & $\ldots$ & $\ldots$ \\
\hline & June & 72.64 & 72.75 & 72.70 & 74.56 & $\ldots$ \\
\hline & July & 70.96 & 71.07 & 71.02 & $\ldots$ & $\ldots$ \\
\hline & August & 72.05 & 72.15 & 72.10 & $\ldots$ & $\ldots$ \\
\hline & September & 70.98 & 71.10 & 71.04 & 71.39 & $\ldots$ \\
\hline & October & 43.18 & 43.32 & 43.25 & $\ldots$ & $\ldots$ \\
\hline & November & 41.81 & 41.94 & 41.88 & $\ldots$ & $\ldots$ \\
\hline & December & 30.25 & 30.39 & 30.32 & 38.48 & 65.69 \\
\hline \multirow[t]{12}{*}{2002} & January & 28.99 & 29.13 & 29.06 & $\ldots$ & $\ldots$ \\
\hline & February & 37.00 & 37.17 & 37.08 & $\ldots$ & $\ldots$ \\
\hline & March & 33.60 & 33.84 & 33.72 & 33.29 & $\ldots$ \\
\hline & April & 34.37 & 34.50 & 34.44 & $\ldots$ & $\ldots$ \\
\hline & May & 37.57 & 37.70 & 37.64 & $\ldots$ & $\ldots$ \\
\hline & June & 36.72 & 36.94 & 36.83 & 36.30 & $\ldots$ \\
\hline & July & 40.14 & 40.32 & 40.23 & $\ldots$ & $\ldots$ \\
\hline & August & 39.20 & 39.38 & 39.29 & $\ldots$ & $\ldots$ \\
\hline & September & 48.26 & 48.46 & 48.36 & 42.63 & $\ldots$ \\
\hline & October & 53.01 & 53.26 & 53.14 & $\ldots$ & $\ldots$ \\
\hline & November & 58.00 & 58.43 & 58.21 & $\ldots$ & $\ldots$ \\
\hline & December & 49.34 & 49.68 & 49.51 & 53.62 & 41.46 \\
\hline \multirow[t]{8}{*}{2003} & January & 46.07 & 46.30 & 46.18 & $\ldots$ & $\ldots$ \\
\hline & February & 48.34 & 48.55 & 48.45 & $\ldots$ & $\ldots$ \\
\hline & March & 51.24 & 51.43 & 51.33 & 48.65 & $\ldots$ \\
\hline & April & 49.64 & 49.81 & 49.72 & $\ldots$ & $\ldots$ \\
\hline & May & 48.36 & 48.57 & 48.46 & $\ldots$ & $\ldots$ \\
\hline & June & 48.66 & 48.81 & 48.74 & 48.97 & $\ldots$ \\
\hline & July & 48.45 & 48.57 & 48.51 & $\ldots$ & $\ldots$ \\
\hline & August & 48.62 & 48.56 & 48.59 & $\ldots$ & $\ldots$ \\
\hline
\end{tabular}

Source: Da Afghanistan Bank. 


\section{Reference}

Frankel, Jeffrey A., 1999, "No Single Currency Regime is Right for All Countries or at All Times,” NBER Working Paper No. 7338 (September), (National Bureau of Economic Research). 


\section{Chapter VI. Financial Sector Development in Afghanistan: SEEKING A RENAISSANCE ${ }^{93}$}

188. After more than two decades of war and conflict, regional tensions, and endemic security concerns, very little was left of Afghanistan's financial system when the Taliban departed at the end of 2001. Although six commercial banks still retained banking licenses, none of them was operational. Virtually no loans had been made since 1995 and banks had lost their credibility as deposit-taking institutions. The central bank had been changed into a Soviet-style dirigiste institution, interfering in the allocation of credit and the setting of interest rates, and abrogating its responsibility to undertake the traditional functions of a central bank. Its financial role was subsumed to monetizing successive governments' fiscal deficits. The banking system could no longer provide a payment system, which was instead taken over by the informal Hawala system.

189. The speed with which Afghanistan's economy can be rebuilt and sustainable economic growth achieved, and ultimately widespread poverty reduced will depend crucially on a rapid and sound redevelopment of its financial sector. ${ }^{94}$ For the government to pay the wages of its civil servants, procure goods and services, and undertake investment in infrastructure, for it to collect taxes and customs duties efficiently, and for Afghanistan to make the best use of the substantial donor funds destined for its reconstruction, a rudimentary payment system and basic financial services are essential. It is thus paramount for the Afghani authorities to quickly initiate reforms to move away from cash as the sole medium of exchange and to lay down the enabling framework for an efficient commercial banking system to flourish. And for all this to be done while safeguarding against fraud and bank failure, it will be necessary to rebuild a modern central bank, with a supervisory capacity in line with international standards to oversee the operations of the new banking system as it develops. ${ }^{95}$

\section{After the Taliban: The Financial System at the End of 2001}

190. At the end of 2001, there was no functioning banking sector in Afghanistan, notwithstanding the existence of a number of financial institutions with valid banking licenses and a roster of staff on the payroll. Most of what remained of the financial system was based in Kabul. Although not much is known about the state of the financial system in

\footnotetext{
${ }^{93}$ Prepared by Felix Fischer.

94 See Holden and Prokopenko (2001) for a literature review on the linkages between the financial sector growth, economic growth, and poverty. See also Levin et al. (2000) for an econometric analysis showing the positive link between financial intermediation and growth. The study also confirms that legal and accounting reforms that strengthen creditor rights, contract enforcement, and accounting practices can boost financial development and accelerate growth.

${ }^{95}$ Banking supervision does not necessarily have to be performed by a central bank. Some countries have chosen to set up a separate institution for this purpose.
} 
the other provinces, it is not believed to have been extensive, let alone operational. The Afghan financial system comprised, in principle, Da Afghanistan Bank (DAB), a hybrid institution with central banking and commercial banking functions, two state-owned commercial banks, and four state-owned special purpose development banks. In addition, there were about 300 registered money trading entities reportedly operating in Kabul with some 5,000 traders.

191. Assessing the conditions of the financial sector in Afghanistan that prevailed at the end of 2001 proved in itself to be a major challenge. Qualified translators were few and the difficult security situation, particularly outside of Kabul, seriously hampered a systematic and rapid assessment of the financial sector on a nationwide scale. Communication lines with most of the branches of the central bank or commercial banks with their headquarters had mostly broken down. In most cases, there had been no exchanges with correspondent banks abroad for years and accurate information on assets and liabilities, either domestic or external, were unavailable. The books kept at the banks in Kabul were completely out of date, and moreover were prepared according to Soviet accounting systems that were incompatible with internationally accepted accounting standards. At the aggregate level, meanwhile, the databases of international institutions, such as the IMF, on Afghanistan's financial sector had not been updated for more than a decade. A proper assessment of the informal financial system, the registered money traders, and the rest of the Hawala was by its nature even harder to make. As a result, information collected was often ambiguous or contradictory and it was impossible to properly assess the soundness of the banking sector, let alone to conduct any due diligence of reported data. It thus took considerable time to assess the post-Taliban conditions of the financial sector and even today the assessment remains approximate.

\section{Legal foundations}

192. The legal basis for the central bank and for the commercial banks was the Law on Money and Banking, which was enacted in 1994. This law has a number of serious flaws. First, it is designed on the now outdated socialist principle that the purpose of monetary policy is to direct credit. It is therefore unsuitable for a market economy. Second, it involves a number of important conflicts of interest between the government, central bank, and commercial banks. Third, it omits important modern prudential standards and enforcement tools. For most of its life, however, the law was irrelevant in practice, as the Taliban largely ignored it during their rule. In order for the financial sector to develop in Afghanistan within a modern legal framework, it would be impracticable to make amendments to this law. The law needed to be replaced in its entirety by a modern central bank law and modern banking law and new legislation is expected to be enacted soon. Box VI.1 summarizes some of the main issues surrounding the outdated Law on Money and Banking. 


\section{Box VI.1. The Law on Money and Banking of the Islamic State of Afghanistan ${ }^{1 /}$}

1. The old 1994 Law on Money and Banking is a compound law of a central bank law and a banking law. The law is poorly written and at times contradictory. Part I defines the legal tender, the Afghani, and its value, ambiguously both in terms of gold and SDRs. It also defines the minimum reserves $\mathrm{DAB}$ has to hold against issued banknotes at 25 percent. It further reserves the right of printing and issuing money to DAB.

2. Part II of the law relates to the DAB, its objectives, responsibilities, and powers, and its organs. It states that DAB is responsible for the implementation of the government's monetary and credit policy and that it shall maintain the value of the Afghani in order to facilitate banking and commercial transactions. It also empowers DAB to supervise operations of banks and credit institutions and to regulate and carry out foreign exchange operations. It mandates DAB to determine the commercial banks' interest rates for deposits and loans and to set minima and maxima on their commissions. DAB is also mandated to define liquidity and capital requirements and limits on large loan exposure. However, these provisions are mostly ill-defined and do not comply with international best practice. There are no loan classification or provisioning requirements. Furthermore, the law only empowers DAB to define ratios and to collect information, but no provisions exist on the enforcement of the regulations. Part II further requires DAB to manage government accounts and, if necessary, to finance the government budget deficit, as well as to grant loans to government institutions, agencies, and municipalities. With respect to loans for government projects, DAB is required to check on the projects' economic and financial efficiency.

3. The final section of Part II defines the composition and the role of DAB's organs, namely the Supreme Council, the Monetary and Credit Committee, the Executive Board, the Board of Supervisors, and the Banknote Reserves Supervision Board. The highest organ is the Supreme Council composed of nine members: the Prime Minister, the ministers of finance, commerce, planning, mines and industries, agriculture and light industries and food products, the minister without portfolio (advising the Prime Minister on economic affairs), and the governor of DAB. The Supreme Council is supposed to meet at least four times a year and decides on all important matters of DAB or on recommendations made by the other supervisory organs. It notably approves all regulations.

4. According to the law, the Monetary and Credit Committee is charged with drafting regulations and recommending the level of interest rates to the Supreme Council. This committee is also charged with determining the accounting principles to be used and advising the Supreme Council on monetary, banking, and credit matters. The Monetary and Credit Committee is composed of the following: the Governor and the First Deputy Governor of the DAB, the Treasury Director of the Ministry of Finance (MoF), the Financial and Commercial Director of the Ministry of Planning, the Foreign Trade Director of the Ministry of Trade, the President of the Chamber of Commerce and Industry, two presidents of state commercial banks, one of a private bank, and one of a specialized state bank (all four selected by the president of DAB), and a professor of economics (specialized in banking) from Kabul University. The composition of the Supreme Council and of the Monetary and Credit Committee is highly problematic as it politicizes decisions that should be made on purely technical grounds. DAB thus lacks the necessary independence that a modern central bank should have.

5. The Executive Board consists of the governor and his two deputies. Upon recommendation of the Supreme Council, the governor is to be appointed by the president for three years. The law stipulates that the members of the Executive Board are not allowed, during their tenure of office, to accept any position in any other government or private institution. Finally, a Board of Supervisors with a chairman and two members would supervise DAB's banking operations and accounting practices, and submit monthly reports to the MoF and quarterly reports to the Supreme Council. This control function has not been fulfilled for years. 


\section{Box VI.1. The Law on Money and Banking of the Islamic State of Afghanistan ${ }^{1 /}$ (concluded)}

6. Part III of the law relates to banking. A bank is defined as an establishment that accepts deposits for the purpose of granting loans or making investments. A special definition is given to "private banks" as institutions whose operations are limited in scope and whose activities consist of "monetary and credit transactions" and the purchase and sale of movable and immovable assets. It defines the conditions for establishing a bank, including its minimum capital requirement and its by-laws. The law further requires banks to use a double entry accounting method and to submit to DAB its annual balance sheet and profit and loss statement within four months following the end of each year, together with an audit report. The law empowers the Supreme Council, upon recommendations of the governor and the Money and Credit Committee, to transfer the management of a bank to DAB, or to take measures for the management of the bank or to close the bank (if, for example, the bank acts against the law or its by-laws). The law allows that liquidation of an insolvent bank would be carried out by a team that could include officials of the failed bank. The involvement of the management of the closed bank is particularly problematic if the bank failed for fraudulent reasons. If a government bank is closed, all outstanding deposits, salaries, and claims of other creditors would be paid by the government. In the case of the closure of a private bank or semipublic bank, the law states that outstanding claims would be paid with the 15 percent of capital the bank deposited with DAB at the time the bank was constituted, without indicating the order of priority.

1/ This box is based on an unofficial translation from Dari into English of the Law on Money and Banking of the Islamic State of Afghanistan. Weaknesses of the law highlighted in this box may stem from an incorrect translation of the Dari version.

193. Other aspects of the legal foundations of the financial system seem, on the face of it, to be less problematic, as they have been derived from Western, market-oriented laws and thus do not bear the communist legacy. ${ }^{96}$ Afghanistan's civil code was adopted in the $1960 \mathrm{~s}$ with assistance of the Egyptian government, and is reported to be almost identical to the civil code of Egypt, originally based on French law. ${ }^{97}$ The commercial code of Afghanistan, in turn, was received from Turkey where it had been modeled after German law. It covers general company law, transport law, insurance law, and special financial transactions. It also includes provisions on bills of exchange, promissory notes, and checks. Finally, bankruptcy law provisions can be found in both the civil code and the commercial code and apply equally to state-owned and private banks. Bankruptcies are administered by the courts. For these laws to be made operational, however, there needs to be the necessary infrastructure:

\footnotetext{
${ }^{96}$ However, a detailed assessment of the old legal framework would be necessary to determine the adequacy and mutual consistency of the laws. Given the variety of origins the legal framework has been built on it is not unlikely that at least parts of the laws could be contradictory or incompatible.

${ }^{97}$ Based on the very rudimentary information available, the property law and the law of obligations could in principle be adequate for supporting banking transactions in Afghanistan. Again, a more thorough review of the laws would be necessary to determine its adequacy for banking activities.
} 
record-keeping institutions, functioning courts and police, and an impartial and independent judicial system. Given the difficult environment in Afghanistan, many of these elements are either not yet in place or are in a state of substantial disrepair.

\section{Da Afghanistan Bank}

194. At the end of 2001, DAB was actively performing two main functions. First, it was cashier to the Ministry of Finance (MoF), and was, in principle, responsible for salary and other budget payments, and receiving government revenues for deposit, across the country. Second, it issued banknotes and managed the stock of cash monies. The bank was also structured around many commercial banking operations that a central bank in a modern twotier banking system would not normally do, while at the same time it omitted many of the typical central bank functions that a modern central bank should do. DAB was meanwhile fulfilling its tasks with a totally inadequate physical infrastructure and security features (see Box VI.2).

\section{Box VI.2. The Physical Infrastructure and Security of Da Afghanistan Bank}

1. A critical weakness of DAB was the design of the main office, which was not adequate for a central bank. Most disturbing were the security features associated with the storage of cash. DAB's main currency reserve stock was held in two major vaults in Kabul. Although there are well established procedures for accessing the vault, requiring two certified key holders and a witness, the vault area was situated near counters to which the general public had access and was not monitored by electronic surveillance or access technology. During banking hours, the security of the premises was entrusted to unarmed guards and armed military personnel. After working hours, the exterior of DAB was patrolled by military personnel. DAB's lack of suitable vehicles and the poor and insecure road conditions made cash transport to the provinces very difficult and highly risky. In early 2002, DAB had only two trucks, one bus, and one Land Rover. All these vehicles were old and unsuited for cash transport. In Kabul City, even now, branch offices must occasionally transport cash to the main office using private cars. Only exceptionally can DAB benefit from air transport provided by the army to deliver cash to the provinces. As a result, cash delivery is often delayed. This has forced some branches to rely on their local provincial authorities and private sources to transport cash from Kabul to the provinces.

195. On the commercial side, DAB offered commercial banking services, extended longterm loans to banks and enterprises, and accepted deposits from the public. Although most of these operations were discontinued in 1995, a number of DAB accounts (debit and credit) are still current. ${ }^{98}$ The governor of DAB remains legally the chairman of the governing boards of all the commercial and development banks. This relationship would have involved a substantial and undesirable conflict of interest with the traditional functions of a central bank,

\footnotetext{
${ }^{98}$ In DAB's headquarters there were only 5,000 active accounts out of a total of 100,000 accounts $(35,000$ of which had a zero balance). In the first 30 branches assessed in May 2002, less than 6,000 accounts were found to be active. Active accounts are defined as those that had any movements since the beginning of the year or that had a customer who declared an interest for his or her account.
} 
in particular with banking supervision, had DAB considered this its duty. As it was, the central banking side of DAB was minimal. DAB did not supervise the banking sector either by issuing prudential regulations or by checking compliance through on and off-site inspections. DAB did not provide or supervise an efficient payment system. Nor did it offer any lender-of-last-resort facility for illiquid but solvent banks. Finally, DAB lacked a meaningful and credible monetary or foreign exchange policy (see Chapter $\mathrm{V}$ for a discussion of monetary and exchange rate policy).

196. While best practice in central banking would require that DAB be granted a high degree of autonomy, combined with stringent rules for accountability, DAB is fully controlled by the government. DAB's ultimate decision making organ, the Supreme Council, as well as the Monetary and Credit Committee, which drafted regulations and governed the operational aspects of DAB, both included representatives from different ministries.

\section{$D A B$ 's organizational structure}

197. At the end of 2001, DAB's organizational structure was based on the soviet monobank system, and therefore inappropriate for a modern central bank in a two-tier banking system. Most importantly, crucial departments were missing or did not perform the functions that their name would have suggested. For example, there was no monetary policy department, banking supervision department (see below), or market operations department. The Planning and Research General Department did not conduct any research and the Supervision and Control of Currency Exchange General Department's main activity was to keep records on the activity of licensed exporters and importers. Finally, DAB had departments that do not belong in a modern central bank, such as the Savings General Department or the Foreign and Domestic Loans General Department. The latter is in charge of keeping the records of defaulted DAB guaranteed loans extended to Afghan entities by foreign banks or governments. The last guarantee was granted 10 years ago, and the last external payment under such guarantees was made in 1997. DAB also had a Pension Department for pensions of the entire financial sector, including commercial banks.

\section{Accounting and control}

198. Although there existed an Accounting General Department, this did not in fact perform the required accounting tasks. DAB had no formalized accounting system or a chart of accounts. Its rudimentary accounting rules were incompatible with principles of materiality (the reflection of all items that are material to the financial statements), prudence (valuation at market value or at cost if lower), and substance (over form). Its systems lacked headquarters-branch data reconciliation, a delineation between central bank and commercial operations, and an appropriate valuation and classification of assets and liabilities, and involved confusion between stocks and flows. There was a complete absence of automation and computerization, and of related technology for accounting, financial analysis, and risk management. In short, using a conventional understanding for accounting, the financial 
information produced by the accounting department was inaccurate and even misleading for disclosure and financial reporting, and thus unsuitable for decision-making. ${ }^{99}$ While the department did keep records of movements in assets and liabilities, income, and expenses, the old National Cash Registry (NCR) card journal entry posting machine used to do this broke down six years ago. This, together with the Taliban's disinterest in financial affairs and the long delays in financial reporting by DAB's branches, meant that DAB had not produced a balance sheet for seven years.

199. DAB also had a Control General Department, which performed preemptive control of every operation recorded by DAB. Authorization of each and every operation required the signature of two representatives of this department. This system led to protracted delays and disruptions in DAB's day-to-day operations and removed all responsibility from mid-level managers. Yet the system also failed to reduce risks. Ex-post internal control in all of DAB's departments and Kabul-area branches was meanwhile performed by the Inspection General Department. But the information collected and processed did not conform with the traditional function of an internal audit department.

\section{Banking supervision}

200. Before the Taliban regime came to power in Kabul, the Planning and Research Department routinely collected statistics from banks without, however, analyzing them. The staff of the department who purported to be supervisors did not have the necessary understanding or capacity for meaningful supervision. And the data collected were in any case mostly irrelevant, for two reasons. First, similar to the accounting practice in DAB, the accounting rules under which the data were produced in the commercial banks did not correspond to international practice, and therefore the data submitted could not be assessed against prudential benchmarks (see below). Second, much of the data collected (number of employees, their profession and gender, and number of buildings and cars) bore no relation to prudential considerations. Some functions related to supervision were also performed in other departments. For example, money changers were licensed by the Foreign Relations General Department and on-site audit was performed by the Inspection General Department. During the Taliban regime, the Planning and Research Department was closed altogether and no banking data of any kind was collected by DAB during this period. In short, such banking supervision as was undertaken was confused with the functions of auditing and checking the bank's activities against the rules set out in its charter, and by the end of 2001, even this activity had largely ceased. Banking supervision in DAB therefore needed to be built from scratch.

\footnotetext{
${ }^{99}$ Conventional central banks have both financial and management accounting. With financial accounting, central banks produce financial statements that reflect the "true and fair value" of their accounts, as well as the profitability of their operations. It further allows for financial control, cost accounting, and information to be made public. Under the management accounting, internal forward-looking financial statements are produced, based on which management derives its information, monitors the financial health of the organization, and, most importantly, takes strategic decisions, including budgeting and planning.
} 


\section{Branch network}

201. In the original design, in addition to its headquarters in Kabul, DAB included 89 branches across the country, six desks in hotels and other public places, and four toll desks on highways. Each of the 30 provinces had a main provincial branch headed by a general director and one or more district level branches headed by a director. The general director in the province oversaw and supported the district branches in that province. As a result of the civil and military upheavals, 24 of 89 branches were closed. This left the provinces of Bamyan, Maidan Shar, Qala E Naw, Zabul, and Nimroz without any functioning branch at all. The provinces of Gardez, Khost, Kapisa, Logar, Ghazni, Kunurha, Qalat, Urazghan, Ghorat, Farah, Badghis, Sar-e-Pol, Baghlan, and Taluqan emerged with only one branch each. Apart from Kabul, which has 15 official branches, the provinces least affected were Nangarhar (with five branches), Kandahar (four), Herat (five), Mazar-i-Sharif (seven), and Kunduz (three). DAB owns 30 branches. The remaining properties belonged to other state institutions and private investors.

202. Although DAB's branches were supposed to report monthly to the main office on branch activities, most branches stopped sending reports six years ago, reflecting the disruption in transportation and communication and the disinterest of the Taliban rulers. ${ }^{100}$ As a result, the main office in Kabul no longer knew its current cash holdings in the branches, which the branches were supposed to surrender to DAB headquarters.

\section{Employment}

203. In mid-2002, despite the low level of activity and the past closure of numerous branches, the staffing level had remained generally unchanged over the years and DAB employed 2,400 staff, of which 1,021 are at headquarters, 1,130 in branches, and approximately 250 at the tolls. A substantial number of staff had no clear responsibility, and many only showed up at work for attendance checks. There was also a conspicuous lack of telephone, telex, and computer operators, reflecting the absence of a modern communication and information system in DAB.

204. Difficulties at DAB's headquarters in making prompt wage payments in its branches resulted in staff in some provinces turning to local political authorities, to which they became accountable. In some instances, these branch employees were also called upon to perform municipal duties. In Ghazni and Gardez provinces, for example, DAB branch staff also ran

\footnotetext{
${ }^{100}$ In early 2002, a major and constant problem for the connectivity of the main office with the branches or with DAB's customers was the lack of communication. Urgent messages from the main office to the branches outside the city were sent via telegram to the provinces of Mazar-i-Sharif, Farab, Jowzjan, Farah, and Kandahar. DAB itself had one direct telephone line, a set of analogue phones for telephone calls within Kabul only, and eleven digital lines, which allow calls within Kabul and to the regional centers in Herat, Mazar-i-Sharif and Kandahar. The situation was even worse with respect to computer hardware and software. DAB had only three older model computers in its main office, but none in the entire branch network. Data processing in DAB has so far been manual and old-fashioned typewriters were virtually the only equipment in use.
} 
the provincial tollbooths. The dependence of some DAB staff on local political authorities was problematic for an effective management of $\mathrm{DAB}$, as their loyalty vis-à-vis the main office was compromised.

\section{The commercial banks}

205. It is not surprising that at the end of 2001, after 23 years of military conflict, the financial system in Afghanistan bore little resemblance to a modern western banking system. During the pro-communist and later the Soviet era (1973-89), the banking system was nationalized and soviet-style accounting, financial control, and management systems were introduced. The situation of the banks deteriorated further during the Mujahedin period and the associated civil strife, with continued government interference in bank management, directed lending, and administered interest rates. Finally, during the Taliban period financial institutions were forbidden to charge interest on their loans or pay interest on deposits. The banks' loan portfolios suffered widespread loan defaults, reflecting the effect of constant warfare and the banks' inability to recover debt. Deposit mobilization collapsed and the banks discontinued lending. During this same period, the registered money changers and the rest of Hawala system replaced the banks in providing payments and liquidity in the economy, as well as certain deposit and lending services.

206. Box VI.3 provides a summary of each bank's history and particularities. In summary, the commercial banks may be solvent and even have a positive cash flow, but this situation is due to real estate they own and returns on foreign currency deposits abroad that had been frozen during the Taliban times. However, none of the banks have been effectively engaged in the banking business for many years, nor do they have a management cadre, an accounting framework, or risk management systems that would remotely resemble modern banking. As such, the six banks should probably be characterized as shell banks, that is, institutions which may have assets and a valid banking license, but cannot become operational without a fundamental restructuring of the banks and a substantial improvement of their management.

\section{Accounting}

207. As with DAB, the commercial banks do not operate according to a defined chart of accounts. While most banks are still using outmoded NCR accounting systems (including DAB), others use the manual Cartotek system. ${ }^{101}$ Neither system is adequate to determine a banks' true financial condition and is thus not appropriate as a management tool. The banks have no system of headquarters-branch reconciliation. Valuation and classification of assets, liabilities, expenses, and income are misleading and do not correspond to international accounting standards. There are also problems stemming from the lack of adequate financial

\footnotetext{
${ }^{101}$ The Cartotek accounting system is a double-entry manual bookkeeping system, in which entries are booked separately for stocks (balance sheet) and flows (profit and loss statement). The data are then transposed into line items in the balance sheet and profit and loss statement.
} 


\section{Box VI.3. Six Licensed Banks in Afghanistan ${ }^{1 /}$}

1. The Banke Millie Afghan (BMA) was established in 1933 as a private bank by a prominent Afghan businessman for trade financing. It is the oldest and largest commercial bank in Afghanistan. Until the establishment of the central bank, DAB, in 1939, BMA is believed to have undertaken some core central banking activities. During the first 40 years, the bank expanded aggressively both domestically and internationally. Until 1994, it maintained six branches abroad in Berlin, Peshawar, Chaman, London, and Panama City. The first six branches in Afghanistan were located in Herat, Kandahar, Andkhol, Mazar-i-Sharif, Gazni, and Agcha. BMA was nationalized in 1974, and since then has been fully owned and managed by DAB. Since its nationalization, the bank has suffered from political interference and consequently weak corporate governance and management structures. Its financial condition deteriorated significantly, and in 1992 it ceased all forms of financial intermediation. In 2002, BMA had five foreign branches (the Hamburg branch has recently been closed), 10 branches in Kabul, and 13 in the provinces, and employed 800 staff. The latest Profit and Loss Statement was prepared in March 1997. BMA owns shareholdings in Pashtany Tejaraty Bank (3.31 percent), in the Industrial Development Bank of Afghanistan (13.57 percent), in the Agricultural Development Bank ( 0.43 percent), and in the Mortgage and Construction Bank (6.40 percent). Its books show investments in 21 companies in the areas of textiles, insurance, oil, carpets, and the national airline, Ariana.

2. The Pashtany Tejaraty Bank (PTB) was set up in 1955 mainly to provide financial services to the growing trade business community. Although the bank was majority owned by the government through DAB, the MoF and the Ministry of Commerce (together with 58.3 percent of shareholdings), its 12 member board had an equal representation from both the private sector and the government. Until its full nationalization in 1974, the bank performed relatively well. Thereafter, the shrinking private sector reduced lending opportunities, and political interference made the bank entirely dependent on DAB for policy directions and operational instructions. By the early 1990s, the bank's operations were limited to receiving payments of government utilities and small value deposits. PTB currently employs 564 staff in its headquarters and 17 branches, of which six are in Kabul, eight in the provinces, and three Pakistan. Despite its branch network, PTB cannot perform payment services as it lacks basic telecommunication facilities. The latest available audited balance sheet is for the fiscal year ending March 20, 1998.

3. The Agricultural Development Bank (AgBank) was established 1954 as the Agricultural and Handicraft Bank by the MoF (with 69.67 percent of shareholdings), DAB (30.03 percent), and Banke Millie Afghan ( 0.30 percent), and has not changed its ownership structure since then. The bank's objective was to provide financial services to small farmers and handicraft producers. After an unsuccessful start, the bank was reorganized and renamed in 1969. In line with an agreement between the government, UNDP, and IDA, the restructured bank refocused its business on financing the agricultural supply chain from producers through to processing and export. At the same time, AgBank received an IDA technical assistance and a credit facility of \$34 million for re-lending and appointed a German general director. AgBank subsequently experienced a period of high growth providing a wide spectrum of short to long-term loans for working capital and investments. During the soviet period, the management changed and put under control of DAB and its Soviet advisors. The bank's activities declined, concentrating on importing and selling Russian equipment, providing fertilizer and financing operating expenses. After the Soviets left in 1989, the bank became inoperative apart from two brief periods of directed loan activity. AgBank has a Board of directors consisting of the governor of DAB as chairman, the deputy ministers of finance, agriculture, and planning, a member of the Farmer's Cooperative Society, the chairman of the Cooperative Society, and the president of the AgBank. Of the once 28 branches throughout the provinces, only eight remain and are situated in Kabul, Jalalabad, Herat, Mazar-i-Sharif, Kondoz, Helmand, Parwan, and Farah. The last audited balance sheet dates 1994. Once employing as many as 1,350 persons, the bank now employs only 230 persons. 


\section{Box VI.3. Six Licensed Banks in Afghanistan ${ }^{1 /}$ (continued)}

4. Established in 1976 by MoF on behalf of a "retirement fund" under its administration ( 80 percent of shareholdings), the Chamber of Commerce (10 percent), the Cooperation for Development for Raisins (3.3 percent), the Cooperation for Karakul (3.3 percent), and the Cooperation for Rugs (3.3 percent), the Export Promotion Bank (EPB), despite its name, mainly financed import letters of credit. Apart from trade finance, no other loans were offered. The bank has two branches, one in Mazar-i-Sharif and one at the general Chamber of Commerce in Kabul. A third branch in Herat was closed in the early 1990s. The bank's operations continued during the Soviet period, but they fell back drastically after 1992 and were effectively suspended under the Taliban regime. The EPB still employs 250 staff.

5. The Industrial Development Bank of Afghanistan (IDBA) was founded in 1973 as a private financial institution by 203 domestic shareholders (60 percent of shareholdings) and six foreign investors, including Chase Manhattan Bank, First National City Bank of New York (predecessor of Citicorp), the International Finance Corporation of the World Bank Group, National Westminster Bank of London, Ltd., Industrial Bank of Japan, Ltd., and Credit Lyonaise of France. The bank provided short and long-term loans to the private sector, state-owned enterprises and joint private-government enterprises, both secured and unsecured loans. Most projects financed were for production in Kabul of alcohol, carpets, shoes, medical products, and textiles. With its nationalization in 1977, its new owners became DAB, the MoF, Pashthany Tejaraty Bank, Bank Millie Afghan, and the Afghanistan Chamber of Commerce. Its activities were disrupted during the Soviet and Mujahedin period and totally halted with the arrival of the Talibans in 1996. Of the original 400 staff, the bank has retained 37 (18 professional and 19 support staff). It has closed its only two branches in Mazar-i-Sharif and Kabul. IDBA is the only bank to have a project appraisal manual, although it is outdated. The last bank balance sheet was prepared in 1997.

6. Mortgage and Construction Bank (MCB) was established in 1948 to finance residential and commercial construction in Afghanistan. From its inception, the bank was majority state-owned. The composition of the private shareholders who control the residual 49 percent of shareholdings is not known as the bank's records were destroyed in a fire during the 1992-96 war. After nationalization in 1974, the bank's share structure was divided between DAB (40 percent ownership), the Afghan Chamber of Commerce ( 30 percent), MoF (20 percent), and Bank Millie (10 percent). MCB has a Board of directors consisting of the governor of $\mathrm{DAB}$, a representative of the ministries of finance, public works, and mines and industry, and a representative of the Kabul municipality, Chamber of Commerce, Banke Millie Afghan, and MCB. Initially, the bank employed 360 persons. This number was reduced to 80 persons during the Taliban regime. The two branches in Herat and Mazar-i-Sharif have been closed and MCB extended its last loan in 1995. Loans typically covered 70 percent of the property value and had maturities of three to five years. Today, MCB's main activity is to collect rents of repossessed buildings and interest rates on some 300 loans, the principal of which had already been collected during the Taliban regime. MCB's last financial statements dates from 1997. 


\begin{tabular}{|c|c|c|c|c|c|}
\hline \multicolumn{6}{|c|}{ Box VI.3. Six Licensed Banks in Afghanistan ${ }^{1 /}$ (concluded) } \\
\hline Name of Bank & $\begin{array}{c}\text { Date } \\
\text { Established }\end{array}$ & $\begin{array}{c}\text { Public or } \\
\text { Private } \\
\text { (at inception) }\end{array}$ & $\begin{array}{c}\text { Date } \\
\text { Nationalized }\end{array}$ & $\begin{array}{l}\text { Number } \\
\text { of Staff }\end{array}$ & Number of Branches \\
\hline Banke Millie Afghan & 1933 & Private & 1976 & 800 & $\begin{array}{l}19 \text { (of which } 9 \text { in Kabul } \\
\text { and } 6 \text { international) }\end{array}$ \\
\hline $\begin{array}{l}\text { Pashtany Tejaraty } \\
\text { Bank }\end{array}$ & 1955 & Private & 1974 & 564 & $\begin{array}{l}17 \text { (of which } 6 \text { in Kabul, } \\
8 \text { in provinces, and } \\
3 \text { international) }\end{array}$ \\
\hline $\begin{array}{l}\text { Agricultural } \\
\text { Development Bank }\end{array}$ & 1955 & Public & n.a. & 230 & 28 (of which 15 remain) \\
\hline $\begin{array}{l}\text { Export Promotion } \\
\text { Bank }\end{array}$ & 1976 & Public & n.a. & 250 & $\begin{array}{l}4 \text { in Kabul, Mazar, and } \\
\text { Herat (Herat branch not } \\
\text { functional) }\end{array}$ \\
\hline $\begin{array}{l}\text { Industrial } \\
\text { Development Bank } \\
\text { of Afghanistan }\end{array}$ & 1973 & Private & 1977 & 37 & $\begin{array}{l}3 \text { ( } 2 \text { in Kabul and } 1 \text { in } \\
\text { Mazar ( } 2 \text { branches now } \\
\text { destroyed }))\end{array}$ \\
\hline $\begin{array}{l}\text { Mortgage and } \\
\text { Construction Bank }\end{array}$ & 1948 & Private & 1976 & 80 & $\begin{array}{l}2 \text { in Herat and Mazar (both } \\
\text { are closed) }\end{array}$ \\
\hline
\end{tabular}

1/ Information in this box is based on interviews in February and July 2002 and May 2003, and on diagnostic studies conducted by the World Bank.

controls and weak verification procedures and monitoring mechanisms. Two major weaknesses in the current accounting framework are the inappropriate booking of nonperforming loans and the absence of their provisioning. In Afghanistan, nonperforming loans are never written off. Some banks transfer these loans together with accrued interests from "loans" to "receivables" in the balance sheet, where the loan would be kept at a value greater than its face value. ${ }^{102}$ Certain banks apply some provisioning rules and punitive interest rates for late payment. However, they are insignificant and do not reflect the probability of nonpayment.

\footnotetext{
${ }^{102}$ A commonly applied accounting rule in many developed countries prescribes that loans which are nonperforming for a year would be written down in the balance sheet to a value of zero. At the same time, a charge in the income statement of the same amount would be imputed under "provisioning," thereby reducing the profit of that year by the amount of the nonperforming loan. However, the client's liability would still remain vis-à-vis the bank, which would enforce the loan contract if necessary through the court system.
} 


\section{Financial situation}

208. In the absence of reliable data and an audit, the banks' financial situation at the end of 2001 can only be guessed at. The banks' main assets consist mainly of foreign currency deposits held abroad, which were frozen during the Taliban regime because of UN sanctions, and real estate, including repossessed houses and the banks' office and branch network. Because of the arrival of many embassies and aid organizations, including the United Nations, the value of real estate has increased rapidly in Kabul since the end of the war, and this has likely raised the value of the banks' asset base accordingly. Most of the banks' other assets were substantially eroded by inflation and/or can probably be written down to zero. For example, most of the banks' loan portfolio is past due by 7 to 15 years and many borrowers are either dead or have disappeared. While some bankers claimed that some of their loans were still recoverable, they conceded that, because of corruption or inefficiency in the court system, they would not attempt to enforce loans but rather negotiate a settlement of the debt. On the liability side, the deposit base has been eroded substantially by the high inflation rates that prevailed until the end of the war, and deposits would now likely represent only a small claim on the asset base. Banks were not aware of substantial outstanding debts, except for defaulted debt on letters of credits. These were, however, mostly insignificant with the exception of the Export Promotion Bank that reports an outstanding debt of $\$ 5$ million. The income situation differs between banks. Some banks generate sufficient income from rents and interest on deposits abroad to cover their overhead and administrative expenses, and fixed and variable costs of their liabilities. Other banks, however, such as the Industrial Development Bank, depend on loans from DAB to cover their expenses. For banks as a whole, collections on nonperforming loans account for less than 1 percent of total income.

\section{Management and employment}

209. The banks' management had not been managing their banks in a modern commercial sense for years. Managers were instead entrusted with executing instructions from the government in line with its many social, political and developmental objectives. Interference in commercial decisions was either made directly through the manager or through the bank's governing board, which is chaired by the governor of DAB. Furthermore, bank managers were appointed on political grounds leading to situations in which banks were run by people lacking any banking experience. Interest rates were first set by a governmental committee independently of the underlying risk of the projects and later were prohibited altogether under the Taliban regime.

210. Staff, management, and board members lack basic banking and operational experience, even in their own assigned areas, and their job descriptions, including responsibilities and accountability, are ill-defined. Operationally, banks do not have any policies, procedures, and well defined communication lines in place to guide management and staff. Banks were lacking any modern automation and information technology. Employees are mostly unfamiliar with computers and have little or no understanding of automation technology, risk assessment, elements of profit and loss, financial flows and stocks, branch management and operations, accounting, lending, deposit mobilization, and 
general banking operations. There has been no training for many years. Staff were regularly turned over with each political upheaval. It is estimated that the six commercial banks together employ nearly 2,000 staff.

\section{The payment system}

211. With the decline of the commercial banking system to a near moribund state at the end of 2001, most domestic and international payments in Afghanistan came to be undertaken by the money dealers (see Box VI.4). As the only viable payment system, this informal financial network had become crucial for the functioning of the Afghani economy. But it is also vulnerable to money laundering, drug trafficking, and terrorist financing. ${ }^{103}$ And at the end of 2001, there was an urgent need for a formal payment system for payments by the government and by the donor community, which for a variety of reasons was not best suited to the Hawala payment system. Not only did the central government need to immediately make salary and other budgetary payments to and collect customs revenues from the provinces, but the success of the currency conversion critically depended on being able to reactivate DAB's branch system for the conversion to take place nationwide. In the absence of a functioning banking system, therefore, the responsibility fell to DAB to provide leadership in the reform and development of the formal national payment system.

\section{Modernizing the Financial Sector in Afghanistan}

\section{A new legal framework}

212. As explained above, the existing Law on Money and Banking is not compatible with a modern two-tier banking system and needs to be replaced by a completely new central bank law and a banking law, properly defining the separate roles of the central bank and commercial banks. The early enactment of a modern central bank and banking law will be crucial for the development of a sound and resilient private banking sector and more generally for macroeconomic stability and growth in Afghanistan. The laws will also be crucial if foreign banks, with their much-needed technology and management know-how, are to be attracted into Afghanistan. For such banks, investing in Afghanistan offers potentially lucrative opportunities, but - given the low institutional development - with substantial risks. It is therefore very important that potential investors are given transparent, predictable, and sound "rules of the game." At the same time, the central bank needs to have the proper tools to regulate and supervise the banking system without government and political interference. This would help to restore the confidence of the public in the banking system and serve to regenerate the deposit base that banks need to be able to extend credit. Toward this end, drafts of central bank and banking laws, prepared with the help of the IMF and benefiting from comments of a number of international organizations, law firms, and consulting firms, have been extensively discussed with senior officials in the Afghan government and are now ready to be enacted as presidential decrees.

\footnotetext{
${ }^{103}$ Afghanistan remains the largest opium producer in the world. See Chapter II (Annex II.1) for an account of opium production in Afghanistan.
} 


\section{Box VI.4. The Money Dealers in Afghanistan ${ }^{1 /}$}

1. There are approximately 5,000 money traders in Kabul, of which some 300 have shops and are licensed by the Supervision Department of DAB. ${ }^{2 /}$ This department licenses money changers for a fee, but does not regulate or supervise them. Some of the unlicensed money traders are affiliated to shops, which typically have two to five traders. Most traders, however, work independently and thus without a license. In provincial towns, there are on average around 80-150 licensed money traders with shops and about 500 traders. Although the Kabul market has existed for only 80 years, the Afghan people have relied on this informal sector for hundreds of years. The money transfer system is usually referred to as the Hawala System. ${ }^{3 /}$ Since the Islamic revolution, when most foreigners left Afghanistan, the money exchange market has been dominated almost entirely by Afghan nationals.

2. Funds can be transferred within 6 to 12 hours from Peshawar, Dubai, or London to Kabul, and with improving communication, the transfer time continues to diminish. Transfers to provinces usually take a little longer. While regional money dealers are mostly located in provincial cities, from where they organize the distribution to villages through their local offices or representatives, the international dealers are mainly based in Kabul. For international transfers, the traditional counterparts are situated in Iran, Pakistan, India, Saudi Arabia, Qatar, the United Arab Emirates, and Oman. Rather than transacting in cash, some clients wire funds to a correspondent account in Peshawar or Dubai, and upon confirmation of receipt of funds, the counterpart is released immediately at the desired destination. Some 10 to 15 of the larger traders have correspondent accounts with banks abroad. Affiliated traders can also benefit from this network. Reputable customers can cash checks or require receipt of the counterpart prior to making the corresponding wire. Such services are usually negotiated at a higher cost. Depending on the amount, destination, financial relationship, the currency of exchange, and security environment, the cost for making international transfers varies between 0 and 2 percent of the amount transacted. Domestic transfers are typically more expensive with an additional charge of $1 / 2$ to 1 percent. In exceptional circumstances, such as immediately after September 11, 2001 and until early 2002, the fees have been as high as 4 percent. In principle, money transfers operate on a netting system with other traders in the provinces or abroad. Physical transfer of cash, or at times in legal or illicit goods, is only made when a trader has no representation in a particular town, or where a net position needs to be settled. Outstanding balances are usually settled between two dealers on a weekly or monthly basis, but at times, when the volume of transactions is high, settlement of accounts are made daily.

3. Besides the transfer of funds, the other main financial service provided by the money dealers is foreign exchange dealing, mainly in U.S. dollars, Pakistani rupee, and Iranian rial. Virtually any currency can be traded. The 30 largest traders cover about 70 percent of all transactions and roughly half of their trading consists of transactions in U.S. dollars. Daily trade volumes in the Kabul foreign exchange market reportedly run to several millions of U.S. dollars, and most of this is transacted in cash. There are no limits on transaction volumes. Traders have reported that buying or selling \$1 million in cash can be accommodated easily. The main market place is in Kabul. It is located close to the gold and silver bazaars and includes shops and operates as an open-cry currency exchange. At the end of each day, dealers store their excess currency and working capital in vaults located in their shops until the next working day.

4. Other financial services include deposit taking, granting of short-term loans, trade finance, and microfinance. However, money traders extend loans or accept deposits only to and from people they personally know and trust. Most of the loans are between traders and are made on an intra-day basis. The money dealers also offer some auxiliary nonfinancial activities, including telephone (GSM and satellite) and fax services, regional and international trade services, and internet access. 


\section{Box VI.4. The Money Dealers in Afghanistan"1/ (concluded)}

5. The money traders operate without standard documentary requirements and usually design and maintain their own documentary policies and procedures. Transactions usually involve comprehensive and detailed records for the entire process of remittance and settlement of each money transfer. The documentation is kept at least until the entire transaction and its settlement is completed. Customers are provided with a document containing a money transfer number or code, which is needed for the purpose of customer identification, payment, and settlement. Some dealers require secondary identification from clients collecting the transferred funds in addition to the transfer number or code. Others maintain a rudimentary "know your customer" policy, requesting photocopies of customer identity such as passports, or identity cards from hospitals or the army. They also record the date of the transaction, the name and address of the sender and recipient, identity card number, transaction number or code, and the name of the transaction counterpart dealer. For regular customers, dealers keep customer files containing invoices and quotations, copies of receipts, transaction contracts, and agreements. Upon request, mostly from established organizations and NGOs, the dealers also deliver receipt and payment confirmation documents to the sender. The (larger) traders keep daily records of the volumes and rates traded and balance their books at the end of each day. Communications with the banks abroad are via fax and satellite phone. The money market is not subject to any reporting requirements or supervision. It is fully based on reputation and trust, but also benefits from self-regulation by the Money Dealers Association formed by the 20-30 leading traders. This association is directed by an Executive Committee, that consists of an executive director and three assistants, and it meets regularly. The Association has unwritten rules of conduct and practices. Traders not respecting these rules can be expelled from the market.

$1 /$ This box draws extensively on a study conducted by the World Bank (Maimbo (2003)), on El Qorchi et al. (April 2003), and on meetings held with money changers in February and July 2002 and May 2003.

2/ Until early 2003, money traders were licensed by the Foreign Relations Department of DAB.

3/ The term Hawala is used throughout the Middle East and means transfer. Equivalent informal transfer systems exist in other countries under a different terminology: fei-ch'ien (China), hui kuan (Hong Kong), hundi (India), padala (Philipines), and phei kwan (Thailand).

213. The draft central bank law includes provisions that give DAB the overriding responsibility to achieve and maintain price stability, and grants it full autonomy in seeking this objective. In order to mark the clear departure from its socialist legacy, the law would also specify that DAB shall act in accordance with the principle of an open market economy with free competition. It would further entrust DAB with the tasks of defining, adopting, and implementing Afghanistan's monetary and foreign exchange policy, issuing banknotes and coins, holding and managing the official foreign exchange reserves, acting as advisor to and as fiscal agent to the government, and licensing, regulating, and supervising institutions engaging in banking business. The law would prohibit financing the government budget deficit, thereby closing one important channel through which macroeconomic instability and high inflation might otherwise emerge. DAB would also be prohibited from providing loans to commercial banks. The one exception to this rule is to permit DAB to act as a lender of last resort and to extend short-term liquidity support to solvent but illiquid banks, especially in the event of a systemic liquidity crisis. 
214. Under the draft law, DAB would be granted complete legal, operational, and administrative autonomy from the state and any other person or authority in the pursuit of its objectives and the performance of its tasks. Independence requires accountability, and this is also stipulated in the law. Accountability would be achieved by a clear mandate and by reporting requirements to Parliament and to the public on DAB's financial condition, and on the achievement of its objectives and on the performance of its task. Accountability would also be enhanced by prohibiting DAB senior officials from holding other government positions and by excluding them from engaging in other tasks incompatible with their duties, and which could put them into conflict of interest. The governor, first deputy governor and members of the Supreme Council of DAB would be appointed, remunerated, and dismissed in accordance with the procedures and conditions specified by law.

215. The law would also stipulate DAB's right to be consulted on any proposed legislative or public administrative act of the government in DAB's field of competence. This provision would ensure that the overall legal framework of the financial system continues to be consistent and coherent. Finally, in consideration of the difficulties involved in passing several laws at the same time, the current draft of the central bank law includes specific issues that under normal circumstances could have been covered by separate laws, including currency, cash payments, payment system issues, and securities services and securities transfer systems. Furthermore, DAB would have the powers to issue regulations for the Hawala dealers as nonbank providers of money and payment services.

216. The main features of the draft banking law would include a precise definition of a bank as an entity engaged in the business of accepting deposits or other repayable funds from the public and using such funds either for extending loans or for making investments for its own account. The law would introduce a two-stage process for applications of banking licenses with only essential information to be submitted in the first stage. It would further give $\mathrm{DAB}$ the mandate to issue regulations to further specify the necessary conditions for obtaining a banking license. The draft law stipulates that before an application is considered, DAB would need to apply a fit and proper test to future owners, board members, and senior managers of the bank. The draft law defines the banking activities that banks are allowed to pursue, as are further detailed in their banking licenses. ${ }^{104}$

217. The law would include the standard rules of a modern banking system with sound management, prudent risk management, and transparent and adequate accounting. Specifically, the law would include provisions related to the banks' corporate governance and on DAB's powers to review changes in bank ownership, as well as the board and senior management level. The law would also include requirements of credit documentation, risk management, as well as provisions that banks should maintain their accounts in accordance with international accounting standards (IAS). Furthermore, banks would be subject to

\footnotetext{
${ }^{104}$ The draft law also provides DAB with the powers to specify by regulation additional activities for banks to the extent not specifically restricted by law.
} 
specific auditing requirements, including the establishment of an audit committee. DAB's oversight role would be strengthened through the conduct of on-site examinations. The last part of the law would be dedicated to specify DAB's enforcement measures to address infractions by banks and situations where a bank's capital declines. It defines a graduated system of prompt corrective actions to be imposed by DAB, including the power to order the removal from office of board members or senior managers of banks, and explicit provisions for dealing with banks having solvency problems. Finally, the law would grant DAB the exclusive authority to revoke a license and to initiate insolvency proceedings, with comprehensive explicit provisions for the resolution of insolvent banks under the oversight of a financial service tribunal.

\section{A modern central bank in a two-tier banking system}

218. In the first 18 months since the end of the war, DAB has made important progress in a number of areas. Most importantly, it successfully implemented the currency exchange and has gained control over the issuance of currency which is a prerequisite for an effective monetary policy (see Chapter V). It has also created a banking supervision department and thereby addressed one of the key weaknesses of DAB. And, as noted above, it is poised to achieve the passage of the central bank law and commercial bank law. Progress in other areas, in particular the restructuring of the central bank, has been slow.

219. Basic training in the business of banking will be a crucial prerequisite for a successful financial sector reform. At the end of 2001, there existed a fundamental misunderstanding by both the banks and the supervisors regarding the role that banks and banking supervision had to perform. In the future, supervisors will be concerned about the safety of the banks' depositors, rather than about any social, political, or developmental agenda. Bank managers, in turn, will be concerned about proper pricing of risk, risk management, and return on equity.

\section{Banking supervision}

220. One of the most important improvements in DAB took place with the initial steps in establishing effective banking supervision. Since the end of 2001, a new Supervision Department has been created, a number of prudential regulations and manuals have been drafted, and the training of supervisors has been initiated. In the first phase, staff received training in the basic balance sheet analysis and concepts of prudential ratios. More recently, and under the supervision of a foreign expert, the staff has been conducting "real life" off-site supervisions of the operating banks and on-site supervision of Bank Millie Afghan.

221. The licensing of money traders has been shifted from the Foreign Relations Department to the new Supervision Department. In November 2002, all licensed money traders had to renew their licenses, a process that had been enforced with the help of the police. The department has now started, as a first step, to improve collection of personal data on the licensed money traders. 


\section{Restructuring}

222. With the exception of the new supervision department, there has been slow progress in the reorganization of DAB, which still runs under its original organizational chart and which continues to employ a large number of unqualified staff with no assignments. Although there has not yet been an overall reorganization, parts of some departments are being restructured individually into what corresponds to a Monetary Policy Department, Payment Systems Department, Accounting Department, Banknote Operations Department, and Banking Supervision Department with foreign experts in each of these departments.

223. The work of the foreign experts has initially focused on the key outputs of these departments by training (and hiring new) personnel, while leaving the remaining departments untouched. The strategy is to recruit national staff from within or outside DAB to perform tasks that should be performed by DAB's staff. This allows hired staff to be better paid and thus motivated, while being under direct supervision of the foreign experts. The objective is to reintegrate these local employees into DAB once DAB's reorganization, including the pay scale, has been implemented.

\section{Accounting reform}

224. On the accounting side, DAB is in the process of introducing a new chart of accounts, as well as computerizing the function to include a general ledger software package that will ultimately enable DAB to produce its balance sheet on a regular basis. However, the reform agenda in the accounting area is still substantial. Accounting regulations still need to be drafted, together with operating manuals and procedures, and staff need to be trained. Furthermore, the consolidation of financial accounts will also depend on the speed of reforms made in DAB's branches. An ambitious project has been initiated to improve the connectivity of DAB's branches with the main office (see below). Improvements have also been made in data collection with the production of a simple quarterly Economic and Statistical Bulletin. Some essential monetary and fiscal statistical data have been collected and work has been initiated for analytical reports.

\section{Commercial operations}

225. DAB has also made notable progress in the efficiency of its commercial services. Almost all banking activities for the international organizations and for many of the NGOs in Afghanistan are currently being conducted by the commercial arm of DAB. Although DAB's services include opening of accounts, deposits, and international money transfers, this is solely to facilitate international payments for international organizations, including USAID, World Bank-funded programs, NGOs, as well as the U.S. army. The efficiency of the payment service has substantially improved with the introduction of SWIFT. Improvements in the commercial area include the development and introduction of procedures that expedite the opening of letters of credit by the MoF under grant programs. New current accounts can 
only be opened by money changers, NGOs, or international organizations, but not by the general public. ${ }^{105}$ With the exception of two recent small loans, one to the Ministry of Defense and another to the Industrial Development Bank, DAB has ceased to extend loans. DAB's commercial arm has been expanding rapidly over the last couple of months. Although these commercial operations do not belong in a central bank, the current vacuum in the banking system leaves DAB with little option but to fill the gap, at least until commercial banks have resumed operations in Afghanistan. When that time comes, DAB intends to divest itself of all the commercial bank activities it now undertakes as soon as possible and no later than end-2004. A conscious effort is being made to develop the commercial activities in such a way that they can be easily split off from the core operations of DAB at a later stage.

\section{Domestic payment system and connectivity of $D A B$ 's branches with the main office}

226. Developments in the payment area by commercial banks will likely be very limited for many months if not years. Meanwhile, DAB has reconnected 35 of its main provincial branches to DAB's head office in Kabul. These branches have been connected by laptops with Immarsat connections, and by end-September 2003 they will be able to report to the center their balances and account movements, with the capacity to do so on a daily basis. ${ }^{106}$ Bank branches in Kabul are already reporting to the head office on a daily basis under the existing communication system. In the near future they will be connected by a computer network. The next step will be to identify the branches that need to be rehabilitated to meet the necessary security standards. The decision on which branch to re-open or to rehabilitate will need to be taken based on a needs assessment and on the estimated reflow of refugees and internally displaced people. The disbursement of government salaries, the main expenditure item in the provinces, would probably require fewer operational provincial branches than existed in the past. ${ }^{107}$ DAB would further need to develop a physical distribution system with some regional cash centers from where the distribution of cash could be made. This would also include the introduction of a software system for the management of the currency inventory and the purchase of an armored fleet or use of an aircraft suited to the important yet risky task of transporting cash within and outside the city. For the medium

${ }^{105}$ In early 2002, DAB has also resumed the payment of interest on the savings accounts.

${ }^{106}$ As the volume of transactions increases, it is planned that the Immarsat connections would be replaced by a VSAT network.

${ }^{107}$ Facilitating the Ministry of Rural Development's scheme to make grant payments to 7,000 villages commencing end-September 2003 using the DAB branch network outside Kabul represents one of DAB's biggest immediate tasks. As regards the MoF individual salary payment requirements, this is still in the planning stage by a taskforce at the ministry. Retail salary payments in Afghanistan are currently made by cash payments at the employees' place of work in the municipalities, rather than by bank transfer to commercial banks (which is not possible) or through individual payments at DAB's branches around the country. However, the number of DAB branches required to undertake this operation is limited by the fact that, after the money has been sent to the local DAB branch, provincial payments are thereafter the responsibility of the local representative of the MoF (Moustoufi). 
term, with the emergence of a commercial banking system, DAB plans to implement two payment systems that will represent the core of the National Payment System. The payment systems will provide the clearing and settlement of both high and low value credit payments, using a Real Time Gross Settlement (RTGS) system and a Direct Giro Credit (GC) system.

\section{Other changes}

227. With the assistance of a foreign expert, DAB is also unblocking and consolidating existing $\mathrm{DAB}$ accounts in international banks and is improving the management of its foreign reserves. Tasks for the future include the removal from the DAB balance sheet of all assets and liabilities held by both the Foreign and Domestic Loans General Department and the Foreign Trade General Department, together with all records associated with them, and their transferal to a public agency designated to settle these balances. DAB will also need to address the pension department, which is responsible for the pensions of employees of both DAB and the commercial banks. Options would include transferring them to an outside private agency or to a national pension system.

\section{Seeking the renaissance of commercial banks}

228. Since the end of the Taliban era, several of the licensed banks claim to have received a small number of new deposits and loan repayments, and to have extended some new loans. But management practices of the licensed banks have not changed. Commercial banks still do not function in a manner consistent with a market economy. Despite the reemergence of some limited banking transactions, therefore, the commercial banking sector in Afghanistan remains dysfunctional. A fundamental restructuring of the currently licensed banks, together with a substantial improvement in their management, will be necessary if these banks are to become modern and efficient banking institutions.

229. The development of an effective banking sector will need to be based on three important pillars: competition, good corporate governance, and strong banking supervision. ${ }^{108}$ The enactment of the draft central bank and banking laws will be the first major step toward this new structure. But the passing of new laws will not be a sufficient basis for the redevelopment of the banking system without improved contract enforcement and well defined property rights. Reforms will be needed simultaneously on a number of different fronts, including accounting reform and training in commercial banking and risk assessment.

230. A good number of reforms can be imported into the banking system by opening it up to foreign banks. Such banks could be expected to have modern management and risk assessment techniques. In-house rules would require them to apply international accounting standards. A number of international banks have already made formal applications for banking licenses, pending the passage of the draft central bank and banking laws. But foreign

\footnotetext{
${ }^{108}$ For experience gained in banking sector reform in Central and Eastern Europe, see Bokros (2001).
} 
banks cannot provide all the answers. To begin with, foreign banks will most likely limit their operations both to the larger cities, starting with Kabul, and to certain type of customers, namely international organizations, NGOs, the diplomatic corps, and the largest corporations, leaving small and medium-size enterprises and rural areas unbanked. Most banks will likely also focus their operations initially on facilitating payments and few can be expected to engage in significant domestic-lending at the outset. This indicates that there remains an important role for DAB, microfinance institutions, and a rehabilitated domestic banking sector to deliver financial services outside of Kabul and to a client basis not served by the international banks.

231. Afghanistan needs a comprehensive medium to long-term financial sector development strategy, possibly including a strategy to rehabilitate part of the current domestic banking system. Such a strategy would likely require an experienced and competent management team to make a detailed diagnostic and action strategy with voluntary retrenchment plans, training of remaining staff, and introduction of modern banking technology. Domestic bank restructuring will only bear dividends if qualified and experienced people are assigned board and management positions; if the organization and corporate governance is well restructured; if the operating systems, management tools, and operating policies and procedures are strengthened and automated; if the duties, responsibilities, and scope of authority at all levels of management and staff are well-defined; and if the bank is sufficiently capitalized after full due diligence and after financial, management, and operational audits have been performed on the banks being restructured. Institutions which are unable to perform should ultimately be liquidated.

\section{Money changers and the Hawala system}

232. Even with the emergence of a modern banking system, the informal Hawala system will likely continue to exist, as is the case in many other countries in the Middle East. Given the need to counter untransparent, undocumented, and adverse practices, DAB will need to evaluate the options available to partly regulate and supervise this market without pushing it underground. ${ }^{109}$ In this context, simply extending banking regulations and supervision practices with respect to licensing requirements, customer identification, suspicious activity reporting, and record-keeping to the money dealers is not a viable option. It would not be feasible to regulate in this manner, given the huge number of traders involved, and this level of regulation would probably push the activity underground and further into the dark. But two alternative options might instead be envisaged. First, the Hawala dealers could, at least as an interim solution, subject themselves to self-regulation and supervision. This market already benefits from an association enforcing a number of unwritten rules. The association could be encouraged to draft written rules and regulations. ${ }^{110}$ Second, recognizing the distinct

\footnotetext{
${ }^{109}$ For a detailed discussion of regulatory options for the Hawala system, see Maimbo (2003).

${ }^{110}$ The disadvantage of self-regulation is that it risks becoming self-serving with a high degree of regulatory forbearance.
} 
features of the Hawala system would justify the development of special regulations and supervision techniques, which would mainly attempt to increase the level of transparency in the business while keeping intact the characteristics that made this market so efficient. Such regulations could include the requirement of registration but not licensing of the Hawala dealers, the requirement to be able to identify customers and to keep records on their identity, and the requirement to cooperate in investigations if the need arises. The latter would also include the right of DAB to enter and inspect the money dealers' premises where there is a reasonable suspicion of a committed offence. Finally, through information campaigns, DAB could seek to educate the money dealers about their responsibility to report suspicious activities. 


\section{References}

Asian Development Bank, 2003, National Payments System for the Islamic Republic of Afghanistan, (draft (B) issued August 19), Final Report TA 3874-AFG, prepared by Schlumberger Sema.

Bokros, Lajos, 2001, "Banking Sector Reform in Central and Eastern Europe," in $A$ Decade of Transition: Achievements and Challenges, ed. by Havrylyshyn Oleh and Seleh M. Nsouli (Washington: International Monetary Fund).

El Qorchi, Mohammed, Samuel Munzele Maimbo, John F. Wilson, 2003, Informal Funds Transfer: An Analysis of the Hawala System, IMF Occasional Paper No. 222 (Washington: International Monetary Fund).

Holden, Paul, and Vassili Prokopenko, 2001, "Financial Development and Poverty alleviation: Issues and Policy Implications for Developing and Transition Countries," IMF Working Paper 01/160 (Washington: International Monetary Fund).

International Monetary Fund, 2001, Guidelines for Foreign Exchange Reserve Management (Washington).

Islamic State of Afghanistan, 1994, The Law on Money and Banking of the Islamic State of Afghanistan (unofficial and unpublished translation from Dari into English).

Levine, Ross, Norman Loayza, and Thorsten Beck, 2000, "Financial Intermediation and Growth: Causality and Causes," Journal of Monetary Economics, Vol. 46 (August), pp. 31-77.

Maimbo, Samuel Munzele, 2003, “The Money Exchange Dealers of Kabul—A Study of the Hawala System in Afghanistan," World Bank Working Paper No. 13 (Washington: World Bank) 